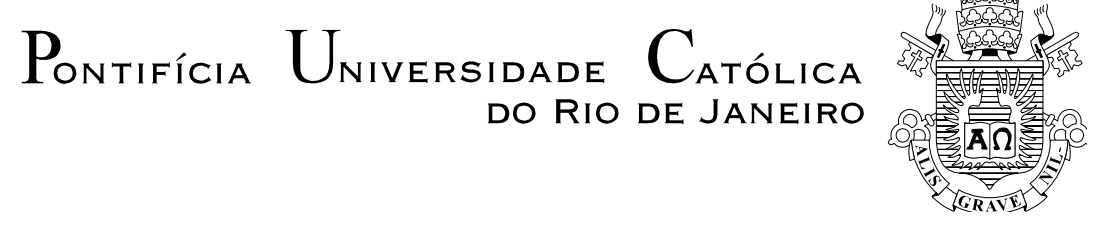

Monica de Freitas Frias Chaves

\title{
LINGUAGEM NA ESQUIZOTOPIA: UM ESTUDO SOBRE REFERENCIALIDADE
}

\section{Dissertação de Mestrado}

Dissertação apresentada ao Programa de Pós-graduação em Estudos da Linguagem da PUC-Rio como requisito parcial para obtenção do grau de Mestre em Letras/Estudos da Linguagem.

Orientadora: Profa. Cilene Aparecida Nunes Rodrigues Coorientador: Prof. Daniel Correa Mograbi 


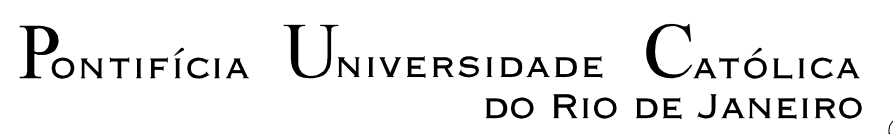

DO RIO DE JANEIRO

Monica de Freitas Frias Chaves

\begin{abstract}
LINGUAGEM NA ESQUIZOTIPIA: UM ESTUDO SOBRE REFERENCIALIDADE
\end{abstract}

Dissertação apresentada como requisito parcial para obtenção do grau de Mestre pelo Programa de Pós-graduação em Estudos da Linguagem da PUC-Rio. Aprovada pela Comissão Examinadora abaixo assinada.

Profa. Cilene Aparecida Nunes Rodrigues

Orientadora

Departamento de Letras - PUC-Rio

Prof. Daniel Correa Mograbi

Coorientador

Departamento de Psicologia - PUC-Rio

Profa. Aniela Improta Franca
UFRJ

Prof. Elie Cheniaux Júnior

UERJ

Profa. Monah Winograd

Coordenadora Setorial do Centro de Teologia

e Ciências Humanas - PUC-Rio

Rio de Janeiro, 20 de abril de 2017. 
Todos os direitos autorais reservados. É proibida a reprodução total ou parcial do trabalho sem a autorização da universidade, da autora e da orientadora.

\section{Monica de Freitas Frias Chaves}

Graduou-se em Letras na Universidade Estácio de Sá (UNESA) em 2008. Cursou Mestrado no Programa de Pós-Graduação Estudos da Linguagem da Pontifícia Universidade Católica do Rio de Janeiro, do qual este trabalho é resultado.

Ficha Catalográfica

Chaves, Monica de Freitas Frias

Linguagem na esquizotopia : um estudo sobre referencialidade / Monica de Freitas Frias Chaves ; orientadora: Cilene Aparecida Nunes Rodrigues ; co-orientador: Daniel Correa Mograbi. - 2017.

115 f. : il. color. ; $30 \mathrm{~cm}$

Dissertação (mestrado)-Pontifícia Universidade Católica do Rio de Janeiro, Departamento de Letras, 2017.

Inclui bibliografia

1. Letras - Teses. 2. Linguagem. 3. Construto da esquizotipia. 4. Desordem do pensamento formal. 5. Referencialidade. 6. Estudo teórico-experimental. I. Rodrigues, Cilene Aparecida Nunes. II. Mograbi, Daniel Correa. III. Pontifícia Universidade Católica do Rio de Janeiro. Departamento de Letras. IV. Título. 
Dedico esta monografia a todos aqueles que me apoiaram em minha caminhada pela vida. Em especial, meu pai (in memorian) minha mãe, meu marido e filhos, pois sem eles eu nada seria. 


\section{Agradecimentos}

Agradeço primeiramente ao meu marido Renato e a meus filhos Mariana e Pedro pela enorme paciência e grande incentivo durante esses dois anos do Mestrado.

À Prof. ${ }^{\text {a }}$ Cilene Rodrigues não só por ser minha orientadora, mas por todo apoio e dedicação a minha pesquisa durante todo o Mestrado. Suas aulas e, acima de tudo, seu exemplo de vida são fonte inesgotável de inspiração.

Ao Prof. Daniel Mograbi pela paciência com que me guiou pelos caminhos da estatística e da psicologia cognitiva, com comentários sempre relevantes e esclarecedores.

À Prof. ${ }^{a}$ Érica dos Santos Rodrigues que com seu jeito ponderado e sereno me introduziu aos encantos e dificuldades da pesquisa quantitativa em linguagem. Bem como por ser uma pessoa com quem podemos sempre contar.

À Prof. ${ }^{a}$ Letícia Sicuro Correa que muito acrescentou ao meu conhecimento sobre aquisição de linguagem, sempre me surpreendendo com textos e discussões interessantes em sala de aula.

A todos professores do Programa de Pós-Graduação de Estudos de Linguagem da PUC-Rio pelas aulas maravilhosas e tão bem elaboradas que possibilitaram meu aprofundamento na área. Dentre eles, não posso deixar de citar a professora Maria Paula Frota com quem tive o prazer de estudar a linguagem sob uma perspectiva histórica.

Aos meus colegas de Mestrado, cujas contribuições durante as aulas e fora delas tanto ajudaram na aquisição e sedimentação de conhecimento, pelo apoio e companheirismo nessa árdua jornada rumo ao saber.

Agradeço ainda à Francisca Ferreira de Oliveira, a Chiquinha, pelo carinho e paciência com que sempre respondeu meus e-mails e questionamentos.

Agradeço ainda ao Prof. Jean Natividade, do departamento de psicologia da PUCRio por tão gentilmente permitir que eu assistisse suas aulas de estatística e me ajudar a entender o programa SPSS.

Agradeço, também, a todos os alunos e amigos que tão gentilmente gastaram 30 minutos de seu valioso tempo respondendo os testes do experimento.

À CAPES e a FAPERJ pelos auxílios concedidos. 


\section{Resumo}

Chaves, Monica de Freitas Frias; Rodrigues, Cilene Aparecida Nunes; Mograbi, Daniel Correa. Linguagem na esquizotipia: um estudo sobre referencialidade. Rio de Janeiro, 2017. 115p. Dissertação de Mestrado Departamento de Letras Pontifícia Universidade Católica do Rio de Janeiro

Esta dissertação é um estudo experimental que busca investigar a construção da referência de expressões nominais inseridas em contextos discursivos. Um dos objetivos foi analisar se falantes nativos do português brasileiro fazem uso de informações dadas no contexto para interpretação de expressões nominais definidas. O outro objetivo foi verificar em que medida presença de traços de personalidade esquizotípica em falantes normais interfere na integração de informações contextuais na construção da referência. Para realizar a investigação, foi conduzido um teste de linguagem acompanhado de dois questionários psicométricos para medir traços gerais de personalidade esquizotípica e traços de desordens do pensamento. $\mathrm{O}$ experimento foi conduzido com adultos universitários do Rio de Janeiro. Os resultados indicam que no geral os falantes do português brasileiro têm preferência por interpretar uma expressão nominal definida como se referindo a uma única entidade, mas são sensíveis às informações dadas no contexto, de modo que a referência de uma expressão nominal definida pode ser uma classe de indivíduos quando o contexto fornece informações ostensivas nessa direção. Correlações entre os resultados do teste de linguagem e os resultados dos questionários psicométricos sugerem que falantes com baixas habilidades para conversas e afeto constrito apresentam possibilidades interpretativas mais restritas, especialmente quando o contexto favorece referência a um único individuo. Embora, a investigação conduzida sobre a relação entre linguagem e esquizotipia seja preliminar, os resultados encontrados indicam possíveis interferências de traços de personalidade esquizotípica na construção da referência pela linguagem.

\section{Palavras-chave}

Linguagem; construto da esquizotipia; desordem dopensamento formal; referencialidade; estudo teórico-experimental 


\section{Abstract}

Chaves, Monica de Freitas Frias; Rodrigues, Cilene Aparecida Nunes (Adviser); Mograbi, Daniel Correa (Co-adviser). Language in Schizotypy: a study on referenciality. Rio de Janeiro, 2017. 115p. Dissertação de Mestrado - Departamento de Letras Pontifícia Universidade Católica do Rio de Janeiro.

This thesis is an experimental study to investigate how the reference of nominal expressions is built within a discourse context. The first goal was to analyze how native speakers of Brazilian Portuguese use contextual information in interpreting definite descriptions. The second goal was to determine whether or not traces of schizotypal personality can interfere in the integration of contextual information in building reference. The linguistic experimental study was accompanied by two psychometric scales. The psychometric scales were used to measure general traits of schizotypal personality and thought disorders. The participants in the experiment were adult native speakers of Brazilian Portuguese from Rio de Janeiro, and the results showed that in general the participants had a significant preference for interpreting a definite description as referring to a single entity. However, they were sensitive to contextual information and reference to a group of entities (king reading) was licensed when the context was favorable. Correlations between the linguistic results and the results of the psychometric scales suggest that speakers with low conversational ability and constricted affect are more restrictive in their interpretation choices, displaying a greater preference for reference to a single entity, especially in contexts favoring single entity reference. Although this is a preliminary investigation, our experimental findings indicate that traits of schizotypy can interfere in how reference is built within language.

\section{Keywords}

Language; schizotypy; formal thought disorder; referentiality; experimental linguistics 


\section{Sumário}

1. Distúrbios da linguagem frente a transtornos mentais 14

1.1 Introdução 14

1.2 Objetivos, questões de pesquisa e hipóteses de trabalho 17

$\begin{array}{ll}1.3 \text { Justificativa } & 18\end{array}$

1.4 Metodologia experimental da investigação 18

1.5 Organização da dissertação 19

2. Esquizofrenia e a Esquizotipia: histórico e caracterização 20

2.1 Esquizofrenia 20

2.2 Esquizotipia 23

2.3 Linguagem no espectro da esquizofrenia 28

2.4 Hipótese evolutiva sobre a relação entre linguagem
e esquizofrenia

2.5 Conclusão parcial 39

3. Linguagem \& Cognição 40

3.1 Loquor, ergo sum! 41

3.2 Arquitetura da mente: teorias sobre a relação
entre Linguagem \& Pensamento

3.3 Referencialidade 44

3.4 Recuperando a discussão sobre referencialidade

$\begin{array}{ll}3.5 \text { Conclusão parcial } & 56\end{array}$

4. Investigando o papel do contexto na construção da referência 58

4.1 Design experimental 58

4.2 Método $\quad 59$

4.2.1 Participantes $\quad 59$

4.2.2 Materiais $\quad 60$

4.2.3 Estímulos linguísticos $\quad 64$

$\begin{array}{ll}\text { 4.2.4 Procedimento } & 67\end{array}$

$\begin{array}{ll}4.3 \text { Análise estatística } & 68\end{array}$

4.3.1 Teste de linguagem 68

$\begin{array}{ll}\text { 4.3.2 Questionário de variáveis de background e correlações } & \\ \text { com o teste de linguagem e com os questionários psicométricos } & 72\end{array}$

$\begin{array}{ll}\text { 4.3.3 Questionários psicométricos (SPQ e FTD-S) } & 73 \\ \text { e correlações com o teste de linguagem } & 77\end{array}$

$\begin{array}{ll}\text { 4.4 Discussão dos resultados } & 77\end{array}$

5. Considerações Finais $\quad 81$

$\begin{array}{ll}\text { Referências Bibliográficas } & 84\end{array}$ 
Anexo 1: Teste de linguagem 100

Anexo 2: Escalas psicométricas de auto-avalição 110

Anexo 3: Questionário de variáveis sociais e linguísticas 113

Anexo 4: Termo de livre consentimento 114 


\section{Lista de Figuras}

Figura 1 - Modelo de esquizotipia 25

Figura 2 - Transmissão da informação

entre áreas assimetricamente distribuídas do córtex humano

Figura 3 - Módulo da linguagem

Figura 4 - A gramática e suas interfaces

Figura 5 - Estímulo, Longchamps (2014) 51

Figura 6 - Estímulo, Longchamps (2014) 51

Figura 7 - Indefinido específico, com reforço, leituras 65

Figura 8 - Indefinido específico, sem reforço, leituras 65

Figura 9 - Nome nu, com reforço, leituras 65

Figura 10 - Nome nu, sem reforço, leituras

65 


\section{Lista de Gráficos}

Gráfico 1 - Julgamento de aceitabilidade em função do tipo de leitura

Gráfico 2 - Julgamento de aceitabilidade em função do tipo de antecedente

Gráfico 3 - Julgamento de aceitabilidade em função do tipo de antecedente e tipo de leitura

Gráfico 4 - Julgamento de aceitabilidade em função do tipo de antecedente e reforço contextual

Gráfico 5 - Julgamento de aceitabilidade em função de reforço contextual e tipo de leitura

Gráfico 6 - Julgamento de aceitabilidade em função de tipo de antecedente, reforço contextual e tipo de leitura 


\section{Lista de Tabelas}

Tabela 1 - Variáveis de background da amostra final 60

Tabela 2 - Organização dos 74 itens da SPQ

nos modelos de 9 e 3 dimensões

62

Tabela 3 - Organização dos itens da FTD-S: 3 dimensões 63

Tabela 4 - Condições experimentais 64

Tabela 5 - Efeitos principais do teste de linguagem 71

Tabela 6 - Informações descritivas das 8 condições

do teste de linguagem

Tabela 7 - Correlações entre as variáveis background e as condições do teste de linguagem $(n=46)$

Tabela 8 - Correlações entre as variáveis background e a Dimensão 2 do FTD-S $(n=46)$

Tabela 9 - Descrição estatística dos 9 fatores do SPQ, incluindo média, desvio padrão, máximo e mínimo obtido nas 9 dimensões

Tabela 10. - Correlações entre SPQ 9 dimensões e condições do teste de linguagem $(n=46)$

Tabela 11 - Descrição estatística da FTD-S, incluindo média, desvio padrão, máximo e mínimo obtido no modelo de 3 dimensões e Total

Tabela 12 - Correlações entre FTD-S (Total e 3 dimensões)

e as condições do teste de linguagem $(n=46)$

Tabela 13 - Correlações entre Dimensão do FTD-S

e Fator Afeto Constrito do SPQ $(n=46)$ 


\section{Lista de Abreviações}

$\mathrm{APA}=$ American Psychiatric Association

$\mathrm{C}-\mathrm{I}=$ Conceitual Intencional

DSM = Diagnostic and Statistical Manual of Mental Disorders

FLB = Faculty of Language Broad Sense

FLN = Faculty of Language Narrow Sense

FTD $=$ Formal Thought Disorder

FTD-S = Formal Thought Disorder Self

GTS $=$ Gyrus Temporal Sulcus

HCF $=$ House, Chomsky \& Fitch

PB = Português Brasileiro

S-M = Sensório Motor

$S P Q=$ Squizotipycal Personality Questionaire

ToM = Theory of Mind

TPE $=$ Transtorno de Personalidade Esquizotípica

WHO = World Health Organization 


\title{
DISTÚRBIOS DE LINGUAGEM FRENTE A TRANSTORNOS MENTAIS
}

\begin{abstract}
"Calcula-se que cerca de 340 milhões de pessoas no mundo inteiro sejam afetadas por depressão, 45 milhões por esquizofrenia e 29 milhões por demência. Os transtornos mentais respondem por uma proporção elevada de todos os anos de vida com qualidade perdidos em função de uma deficiência ou transtorno, e a previsão é que esse ônus cresça significativamente no futuro" (Livro de recursos da OMS sobre saúde mental, direitos humanos e legislação, 2005: 1).
\end{abstract}

\section{1}

\section{Introdução}

A Organização Mundial de Saúde estima que pelo menos $10 \%$ da população mundial manifeste algum tipo de transtorno que afeta a saúde mental e o comportamento (WHO, 2001). Isso significa que uma a cada 10 pessoas no mundo sofre com algum tipo de transtorno mental. É, portanto, importante entender os transtornos mentais. Por exemplo, que funções cognitivas se desestruturam quando o indivíduo é acometido por transtornos dessa natureza? Mais especificamente, que aspectos da linguagem são afetados?

Nos últimos cinquenta anos, houve grande interesse, por parte de pesquisadores de diferentes áreas, a respeito do funcionamento da linguagem nos transtornos mentais (Chaika, 1982; Andreasen, 1979, 1986; Kuperberg, 2010a, 2010b; Chapman, 1966). De um lado, estão aqueles com interesses de ordem neurológica (e.g. Gordinier \& Docherty, 2001) e, de outro, interessados em entender a linguagem enquanto faculdade mental de ordem cognitiva (e.g. Ditman \& Kuperberg, 2007), e seu papel no desenvolvimento e na evolução da espécie (e.g. Crow, 1997a, 2008). De qualquer forma, pesquisas sobre a questão requerem uma abordagem interdisciplinar.

Buscando juntar o conhecimento da neuropsicologia e da linguística formal, um braço da nossa pesquisa volta-se para a investigação sobre a organização da linguagem em indivíduos com esquizotipia: construto multifatorial representativo de um conjunto de traços de personalidade, que predispõe o indivíduo ao desenvolvimento de transtornos mentais do espectro da esquizofrenia. Nos 
detemos particularmente na busca por correlações entre falhas na construção da referência linguística e traços de personalidade esquizotípica.

Referência é a relacão entre as coisas do mundo externo (e.g., objetos e situações) e os signos linguísticos que usamos para expressá-las (e.g. palavras e sentenças). Deste modo, é por meio do precesso de referenciação que usamos a linguagem para nos comunicar sobre as coisas do mundo. Em sentenças como (1), por exemplo, a expressão nominal definida o kiwi pode faz referência a um tipo de fruta (i.e. kiwis no geral), e o adjetivo ácida para fazer referência a uma propriedade química encontrada na natureza.

(1) O kiwi é uma fruta muito ácida.

Note, no entanto, que a relação entre signos linguísticos e coisas do mundo é indireta. Em (1), por exemplo, a expressão nominal definida "o kiwi" pode se referir a kiwis genericamente, mesmo para falantes que nunca viram um kiwi específico. A relação direta dos termos linguísticos é, portanto, com o conceito, ideia ou representação mental que fazemos das coisas do mundo. Assim, entendese que os signos linguísticos fazem referência a conceitos, que, por sua vez, referem-se a coisas do mundo externo. Evidência para isso é o fato de que todo termo linguístico com significado vincula-se a um conceito/representação mental, mas nem sempre a um objeto no mundo, como é o caso de termos como "lobisomem" e "unicórnio". Além disso, um único objeto no mundo pode vincular-se a mais de um conceito. Tome, como exemplo, referências ao planeta Vênus. Embora, a astronomia moderna nos diga que a estrela D'Alva é o planeta Vênus e que a estrela Vésper também é o planeta Vênus, não é certo que a sentença “a estrela D'Alva é igual a estrela Vésper" seja verdadeira, dado que temos representações mentais diferentes para as expressões nominais " $a$ estrela D'Alva" e "a estrela Vésper", com modos de apresentação diferentes (Fregue, 1892).

Em resumo, a relação de referência entre signos linguísticos e objetos no mundo se dá indiretamente via representações mentais. Essas representações são, portanto, o elo entre a linguagem e a realidade externa, e refletem um processo inerentemente cognitivo. 
Por se tratar de um processo cognitivo, a referencialidade linguística pode sofrer alterações quando a cognição é afetada de alguma maneira. Isto é o que se observa no construto da esquizotipia, em especial no transtorno da esquizofrenia, que leva a uma quebra do elo entre o pensamento e a realidade (Bleuler, 1911).

Desde Bleuler (1911), entende-se que esquizofrênicos apresentam rupturas das funções mentais que tecem a ligação entre pensamento e realidade, e essas rupturas emergem na fala distorcida do paciente. Considere como exemplo, o dado abaixo (Andreasen, 2009:56), no qual a fala obliqua do paciente reflete um pensamento não coeso:

Entrevistador: De que cidade você é?

Sujeito: $\quad$ Bem, essa é uma pergunta difícil de responder, porque meus pais... Eu nasci no estado de Iowa, mas sei que sou branco e não negro, então aparentemente eu vim de algum lugar do norte, e não sei de onde. Sabe, eu realmente não sei se sou irlandês ou escandinavo, ou não. Não acredito que seja polonês, mas acho que sou, acho que talvez eu possa ser alemão ou galês.

Mais recentemente, além de se verificar que as disfunções mentais da esquizofrenia estão presentes em todo continuo da esquizotipia (Ott et al., 2002), tem-se defendido que essas disfunções podem ser reflexos de problemas na linguagem, especialmente na maneira como a referência a objetos do mundo externo é construída (Hinzen \& Rosselló, 2015; Zimmerer et al., 2017; Hinzen, 2012). Por exemplo, esquizofrênicos com desordens do pensamento formal (FTDFormal thought formal) tendem a fazer uso desproporcional de expressões genéricas, como wifes, mankind e stuff, mesmo quando se referem a objetos específicos do mundo (Rochester \& Martin, 1979; Hinzen \& Sheehan, 2013). A referência genérica é observada também em associações semânticas vagas, como ilustra o exemplo abaixo, em que o paciente nos dá uma lista de coisas que ele gosta de comer sem tecer uma relação semântica clara entre eles.

Sujeito: Okay what else do you want me to talk about?! I like peaches! I like pears! I like plums! I like apples! I like vegetables! but I like I 
like things that are sweet! I like steak! and I like stuff like that! but I like sweet things sort of sweet tasting! I like beaver! I like bear! I like I never tried muskrat! I like I like milk! and I like I like fruit!

Tem-se salientado ainda que as falhas na construção da referência na esquizofrenia refletem falhas na integração e uso de informações dados no contexto discursivo. Isto é, a esquizofrenia leva a uma insensibilidade às pistas contextuais necessárias para a construção da referência linguística (Kuperberg, et al. 1998; Kuperberg et al. 2006).

Dado o quadro linguístico acima, apresentamos a presente pesquisa como um primeiro passo na investigação sobre a construção da referencialidade no construto da esquizotipia. O foco específico da pesquisa é o uso de informações disponíveis no contexto verbal para a construção da referência de expressões nominais definidas, como a expressão "o kiwi” em (1) .

\section{2}

\section{Objetivos, questões de pesquisa e hipóteses de trabalho}

Nessa dissertação descrevemos um estudo experimental por nós realizado com objetivo de:

(a) Investigar entre falantes nativos do Português Brasileiro (PB) a construção da referência de expressões nominais definidas mediante contexto de fala. Ou seja, nossa primeira meta foi verificar quão sensíveis a informações contextuais os falantes do PB são na construção da referência de expressões nominais;

(b) Verificar possíveis correlações entre os resultados encontrados no experimento linguístico e traços de personalidade esquizotípica, detectados por meio de escalas psicométricas usadas na pesquisa.

Desse modo, as principais perguntas que nortearam a pesquisa foram:

(a) Quão sensíveis os falantes são ao contexto verbal na construção da referência de expressões nominais definidas? 
(b) A esquizotipia pode levar a alterações na sensibilidade ao contexto verbal, causando, assim, diferenças na intepretação e construção da referência de expressões linguísticas?

Nossas hipóteses de trabalho são:

(a) Falantes nativos de PB no geral levam em consideração informações/pistas vindas do contexto de fala para a construção da referência nominal;

(b) A presença de traços de esquizotipia leva a alterações na sensibilidade a informações fornecidas pelo contexto. No caso em questão, a alterações na percepção e interpretação das pistas para a construção da referência de expressões nominais definidas.

\section{3}

\section{Justificativa}

Primeiramente, observamos que não encontramos na literatura estudos sobre a referencialidade linguística focados especificamente na esquizotipia não clínica. Portanto, a pesquisa que aqui apresentamos é possivelmente uma primeira contribuição para uma melhor compreensão dessa questão.

Acreditamos ainda que resultados de pesquisas na área da linguística podem auxiliar investigações em outras áreas do conhecimento na caracterização empírica e teórica da cognição humana frente a transtornos mentais. Além disso, consideramos possíveis contribuições para a área clínica, auxiliando na elaboração de diagnósticos que possam antever um possível surto, e na elaboração de terapias e outros tipos de recursos de intervenção no desenvolvimento de transtornos mentais.

\section{4 .}

\section{Método experimental da investigação}

Dado a natureza da presente pesquisa, fizemos uma investigação com metodologia experimental nos moldes das pesquisas em sintaxe experimental. 
O experimento realizado consistiu em uma tarefa de julgamento de aceitabilidade off-line com uso de escala Likert de 4 pontos para avaliação de escolhas interpretativas de expressões nominais definidas dentro de contextos imediatos de fala. No experimento linguístico, com design $2 \times 2 \times 2$, manipulamos os seguintes fatores: tipo de antecedente disponível no contexto (expressão nominal indefinida no singular e nome nu no singular (bare singular noun)), presença ou ausência de reforço contextual, tipo de leitura da expressão nominal definida (leitura classe e leitura de indivíduo). Os participantes (46) foram universitários com idade média de 25.5 anos residentes no Rio de janeiro. Além do teste linguístico, foram passadas também duas escalas psicométricas (SPQ e FTD-S) para identificação de traços de esquizotipia entre os participantes, e um questionário para caracterização de variáveis socais de pano de fundo, como idade, sexo, escolaridade, presença de doenças mentais e de problemas linguísticos na família. Os resultados linguísticos foram tratados estatisticamente (ANOVA com medidas repetidas) e, em um segundo momento, foram correlacionados com os resultados obtidos para as escalas psicométricas.

\section{5}

\section{Organização da dissertação}

No capítulo 2, apresentamos um panorama geral da esquizofrenia e outras esquizotipias, com foco nos distúrbios de linguagem e a relação com FTD.

No capitulo 3, discutimos o papel da linguagem na cognição humana e questões relativas a sua arquitetura, especialmente no que tange à relação entre linguagem e pensamento. Apresentamos também uma breve descrição dos aspectos semânticos e pragmáticos relacionados à construção da referência de expressões nominais definidas. Considerando questões observadas no processo de aquisição da linguagem, repensamos o que as dificuldades com a construção da referência de expressões nominais nos mostram sobre a linguagem e o pensamento na esquizofrenia e outras esquizotipias.

No capitulo 4, apresentamos os detalhes do experimento realizado e discutimos os resultados obtidos.

No capítulo 5, concluímos a dissertação, retomando os principais pontos discutidos ao longo da texto e apontando para possíveis desdobramentos da pesquisa aqui apresentada. 


\section{Esquizofrenia e Esquizotipia: histórico e caracterização}

Neste capítulo discutimos a esquizofrenia e o construto da esquizotipia, com ênfase nos sintomas de comprometimento da linguagem. Nosso objetivo é traçar um panorama da relação entre transtornos mentais e linguagem, descrevendo brevemente pesquisas já realizadas e suas interpretações dos transtornos em questão.

\section{1}

\section{Esquizofrenia}

A esquizofrenia (e doenças desse espectro) é um transtorno de difícil diagnóstico. Desde 1952, buscando integrar os diferentes entendimentos sobre as doenças mentais e auxiliar na elaboração de critérios gerais de diagnóstico, a Associação Americana de Psiquiatria (APA) elabora o "Manual de Diagnóstico e Estatístico dede Doenças Mentais" (DSM). No DSM-V, de 2014, a esquizofrenia e transtornos do espectro da esquizofrenia estão definidos da seguinte maneira:

\footnotetext{
"O espectro da esquizofrenia e outros transtornos psicóticos inclui esquizofrenia, outros transtornos psicóticos e transtorno (da personalidade) esquizotípica. Esses transtornos são definidos por anormalidades em um ou mais dos cinco domínios a seguir: delírios, alucinações, pensamento (discurso) desorganizado, comportamento motor grosseiramente desorganizado ou anormal (incluindo catatonia) e sintomas negativos." (APA, 2014:87)
}

A esquizofrenia é uma síndrome clínica heterogênea, na qual os indivíduos apresentam grande variação e combinação de sintomas, o que dificulta ainda mais seu diagnóstico. Portanto, uma série de critérios devem ser considerados com intuito de distingui-la de outros transtornos psicóticos. O DSM-V elenca alguns critérios básicos para o diagnóstico deste transtorno, que vão desde critérios a respeito dos sintomas principais, passando por critérios sobre tempo/duração das manifestações, até critérios de exclusão, que descartam transtornos com semelhantes sintomas.

O critério A do diagnóstico, que trata dos sintomas relacionados aos domínios da doença, determina que pelo menos duas de suas cinco anomalias centrais devam estar presentes, sendo que dentre elas, uma deve ser delírio, 
alucinação ou pensamento/discurso desorganizado. A seguir, o texto conforme aparece no DSM-V.

\begin{abstract}
"Pelo menos dois sintomas do Critério A devem estar presentes durante parte significativa do tempo em um mês ou mais. Pelo menos um desses sintomas deve ser a presença clara de delírios (Critério Al), alucinações (Critério A2) ou discurso desorganizado (Critério A3). Comportamento grosseiramente desorganizado ou catatônico (Critério A4) e sintomas negativos (Critério A5) podem também estar presentes.” (APA, 2014:100)
\end{abstract}

Delírios são definidos como crenças fixas, que não se modificam nem mesmo à luz de evidências antagônicas e conflitantes. Dentre os tipos de delírios encontram-se os delírios de perseguição (e.g. o indivíduo acredita ser vítima de conspirações), os delírios de referência (e.g. significado pessoal é atribuído a ações, observações e declarações de outras pessoas, bem como a objetos ou eventos) e os delírios de controle (e.g. o individuo sente como se uma força externa manipulasse seus pensamentos).

A alucinação ocorre quando se experimenta, sem possibilidade de controle mental, algum tipo de percepção sem estímulo externo. $\mathrm{Na}$ esquizofrenia e em transtornos associados, as alucinações são majoritariamente auditivas.

A desorganização do pensamento ou desordem do pensamento formal (Formal Thought Disorder - FTD), expressa na fala do paciente, pode se apresentar de diferentes maneiras. De acordo com Andreasen (1979), o que foi definido como um sintoma aparentemente único (Bleuler, 1911), refere-se, na verdade, a um conjunto de comportamentos linguísticos conceitualmente distintos, que nem sempre são manifestos pelo mesmo paciente. Voltaremos a essa questão na seção 2.3.

A esquizofrenia começou a ser descrita na metade do século XIX. Nessa época, psiquiatras europeus iniciaram a descrição de transtornos de causas desconhecidas que afetavam principalmente jovens e que progrediam para uma deterioração crônica. Emil Kraepelin, em seus escritos de 1983 a 1927, foi o primeiro a propor que a variedade de quadros clínicos com esse tipo de desenvolvimento fossem integrados sob uma única entidade nosológica ${ }^{1}$ com o nome de dementia praecox, pois percebeu que muitos dos casos clínicos observados exibiam um mesmo padrão de desenvolvimento que sempre resultava

\footnotetext{
${ }^{1}$ Doença individualizada, com características e propriedades inerentes à patologia.
} 
em um quadro de declínio cognitivo e comportamental severo. Kraepelin descreveu os sintomas sem no entanto apontar qual ou quais seriam os principais, dada a diversidade e mutabilidade observada. No entanto, na oitava edição de seu tratado (1913), o psiquiatra caracteriza a dementia praecox em duas grandes síndromes: (a) "o enfraquecimento das atividades emocionais que formam as molas propulsoras da volição" e (b) "a perda da unidade interna das atividades do intelecto, emoção e volição" (Elkis, 2000:23).

Bleuler (1911) salientou que o que se observava não era uma deterioração precoce das capacidades mentais, mas algo como uma separação ou quebra de funções mentais que, em pessoas normais, operam de forma integrada na coordenação do pensamento, do afeto e do comportamento. A partir dessa observação, Bleuler cunhou o conceito de esquizofrenia (que em grego significa “divisão na mente"), enfatizando também que os sintomas principais da condição são expressos por meio da fala do paciente.

Somente na segunda metade do século XX, surgiram teorias genéticas para a esquizofrenia. Meehl (1962) foi o primeiro pesquisador a enfatizar o papel da genética na etiologia da doença, que, para o autor, resulta da combinação entre fatores genéticos, determinante do funcionamento neural, e fatores do ambiente social, desenrolando-se em uma ampla gama de expressões clínicas e subclínicas (Meehl, 1962, 1990; Lenzenweger, 2006). Meehl propôs, desse modo, o termo esquizotaxia para o que chamou de defeito integrativo que predispõe à esquizofrenia (Meehl, 1990) e, usando um termo elaborado por Rado (1960), chamou de esquizotipia a organização psicocomportamental resultante de interações entre vulnerabilidade genética - "defeito" na formação e funcionamento cerebral - e fatores ambientais (Raballo \& Parnas, 2011).

O modelo proposto por Meehl é ainda hoje o modelo central de pesquisa em esquizofrenia (Lenzenweger, 2015), pois elabora sobre fatores genéticos, influências sociais aprendidas e sintomatologia clínica, além de criar hipóteses sobre questões cerebrais que levam à condição ${ }^{2}$.

Assim, estudos atuais de cunho empíricos e de simulação (Lenzenweger, 2006) sugerem que um modelo misto no qual uma base genética (biológica) interage com outros fatores na construção do quadro clínico da esquizofrenia é o

\footnotetext{
${ }^{2}$ No modelo de Meehl, um único gene influencia o desenvolvimento do cérebro e codifica uma alteração a nível neuronal, dificultando seu funcionamento.
} 
mais plausível. Tais outros fatores incluem provavelmente o histórico de aprendizagem do individuo (influências do ambiente social) e fatores potencializadores (dimensões da personalidade, tais como introversão social, propensão à ansiedade, agressividade e diminuição da capacidade de sentir prazer). Esses potencializadores interagem com o desenvolvimento da organização da personalidade esquizotípica e o meio ambiente para deflagrar (ou prevenir) o desenvolvimento da psicose.

Atualmente, entende-se que a esquizofrenia representa a expressão mais acentuada de traços de personalidade compreendidos dentro do contínuo multifatorial conhecido como esquizotipia (Lenzenweger, 2006 e 2015; BarrantesVidal et al. 2015; Cohen et al., 2015). A esquizofrenia e os outros transtornos do espectro da esquizofrenia são, nesse entendimento, manifestações clínicas de características presentes em diferentes níveis na população em geral.

A desordem do pensamento formal (FTD), manifestação central da doença, e seus distúrbios linguísticos característicos refletem de algum modo disfunções mentais compartilhadas por todo contínuo da esquizotipia (Ott et al. 2002; Barrera et al., 2015).

\section{2}

\section{Esquizotipia}

A Esquizotipia é assim um construto multidimensional complexo que se manifesta por meio de um conjunto de traços de personalidade. Neste construto, conjuntos de traços de personalidade se expressam em um contínuo que vai desde manifestações suaves até manifestações exacerbadas desses traços (Raballo \& Parnas, 2011; Lenzenweger, 2006 e 2015; Cohen et al., 2015). Isso significa que, ao longo do contínuo, estão incluídos indivíduos saudáveis, bem como indivíduos com diferentes graus de transtornos mentais. A esquizofrenia reflete o mais alto grau de expressão da esquizotipia, que também se manifesta clinicamente em outros transtornos mentais (como por exemplo, o transtorno de personalidade esquizotípica - TPE) ao passo que manifestações mais suaves são encontradas na população em geral, na qual a presença desses traços não configura transtorno de personalidade. De acordo com o DSM-V, "traços de personalidade são diagnosticados como um transtorno de personalidade apenas quando são 
inflexíveis, mal-adaptativos e persistentes, causando prejuízo funcional ou sofrimento subjetivo significativos" (APA, 2014: 648).

Apesar das diferentes abordagens ${ }^{3}$, a esquizotipia é consensualmente entendida como parte da etiologia da esquizofrenia. Portanto, argumenta-se que esse construto apresenta diferentes alternâncias em sua expressão, dando origem a diferentes perfis, desde anormalidades não observáveis objetivamente sem o uso de testes (e.g. pensamento mágico) até casos clínicos de transtorno de personalidade, sendo o mais grave a esquizofrenia. Assim, a esquizotipia se manifesta em um contínuo dinâmico de sintomas e comprometimentos funcionais; ou seja, um contínuo na dimensão da personalidade (organização neurobiológica, cognitiva e socioafetiva).

Durante o período de crescimento de um indivíduo, um conjunto de endofenótipos ${ }^{4}$ associados a genes de risco influencia de forma consistente o processo de organização da personalidade do indivíduo (Lenzenweger, 2006; Debbané \& Barrantes-Vidal, 2015). Cada um dos endofenótipos é parcialmente responsável pela esquizotipia. No período que vai da metade da infância até a adolescência, como consequência dos fatores genéticos que engatilham a esquizotipia, certas experiências metacognitivas, interpessoais e sociais podem ganhar ênfase, ou mesmo ter preferência nas seleções feitas pelo indivíduo (e.g. avaliação seletiva de aberrações perceptivas, excentricidade na fala e comportamento, declínio do contato social etc.). Esse processo pode, portanto, levar ao aumento do risco da psicopatologia. A figura 1 (à direita uma adaptação do modelo desenvolvido por Lenzenweger (2006) com base em Meehl (1962 e 1990), e à esquerda as modificações sugeridas por Debbané \& Barrantes-Vidal (2015) para o modelo) exemplifica o processo de interações entre informações genéticas, neuroestruturais e ambientais, que durante o desenvolvimento do

\footnotetext{
3 A diferença básica é quanto ao fator genético: pesquisadores que seguem a hipótese de Meehl e suas variâncias postulam que o gene (ou genes) da esquizotipia está presente ou ausente no indivíduo. Apenas os portadores desse conjunto de genes (que pode apresentar diferentes endofenótipos) são vulneráveis à esquizofrenia. Ou seja, a esquizotipia tem uma estrutura latente qualitativa. Do outro lado, estão os que postulam que a esquizotipia está presente em maior ou menor grau em quaisquer indivíduos; ou seja, sua estrutura latente é quantitativa. (Cohen et al, 2015; Lenzenweger, 2015).

${ }^{4}$ Endofenótipos são variáveis genéticas no nível neurofisiológico ou neurocognitivo.
} 
indivíduo podem impulsionar manifestações não clínicas de traços de esquizotipia para estados de risco em potencial. ${ }^{5}$

Figura 1.

Modelo de esquizotipia (Debbané \& Barrantes-Vidal, 2015: 390) ${ }^{6}$

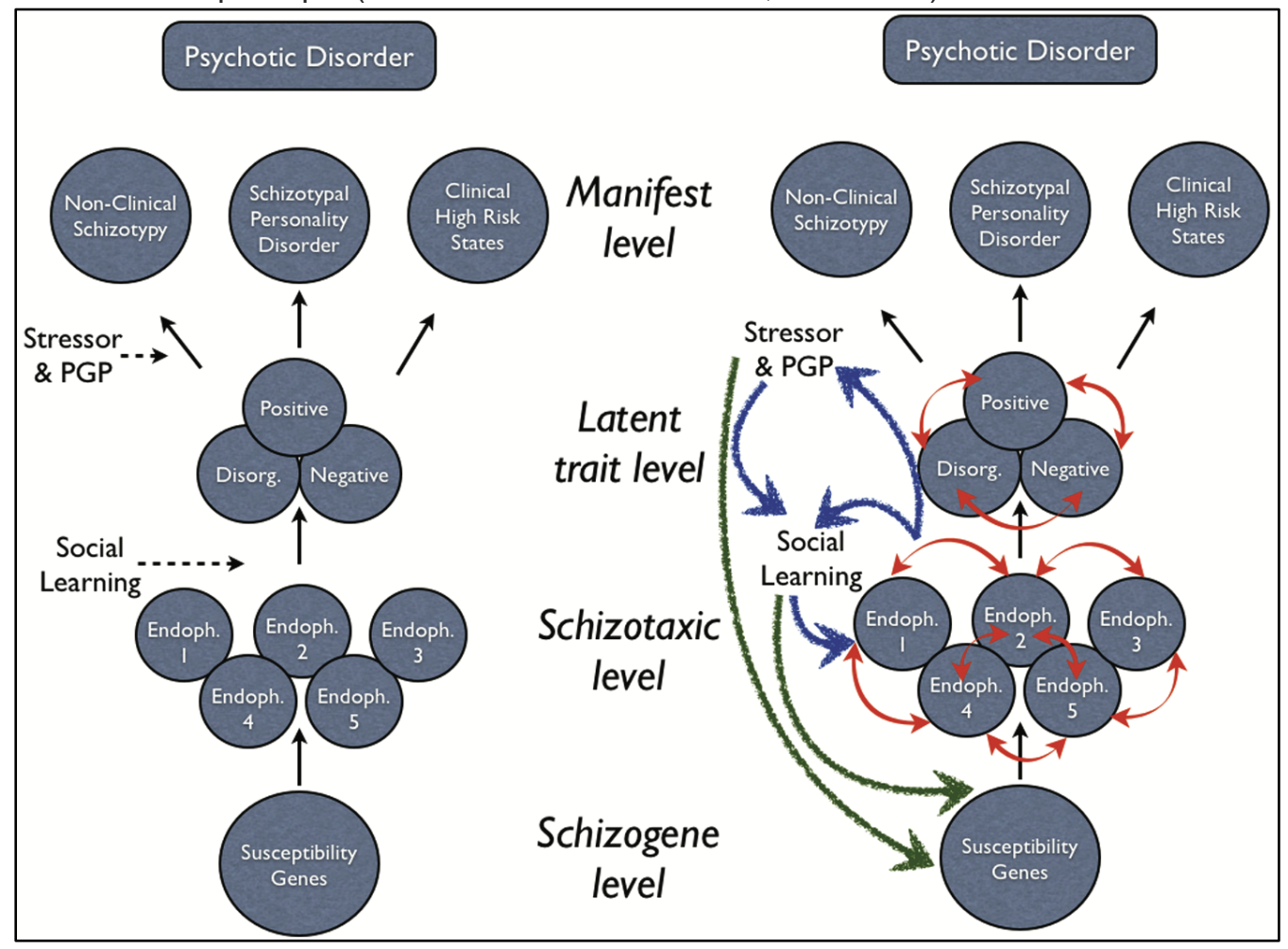

Sendo a esquizotipia entendida como variadas expressões de uma mesma vulnerabilidade à psicose, os resultados obtidos nos instrumentos psicométricos usados para medir esquizotipia (ver descrição das escalas no capítulo 4) podem apresentar, também, uma ampla gama de variação entre indivíduos que se reflete nas diferentes pontuações computadas. Portanto, estudos de avaliação

\footnotetext{
5 Tomando como base o modelo desenvolvimentista proposto por Debbané \& Barrantes-Vidal (2015) podemos levantar a hipótese de os diferentes endofenótipos resultantes da suscetibilidade genética estarem relacionados a desvios de aquisição da linguagem que, dependendo do grau de sua manifestação, podem (ou não) passar despercebidos. Essa hipótese implica que tais desvios (independentemente do grau de manifestação) estariam na origem dos distúrbios de linguagem observados nos transtornos mentais. Crow (1997b) argumenta que a relação entre possíveis desvios durante o período de aquisição da linguagem e quadros posteriores de esquizofrenia merece atenção especial, principalmente quando relacionados ao processo de lateralização da linguagem. $\mathrm{O}$ autor enfatiza a importância de uma investigação detalhada sobre quais aspectos da linguagem distinguem indivíduos que desenvolvem transtornos psicóticos daqueles que apresentam problemas puramente de linguagem (e.g. DEL e Dislexia).

${ }^{6}$ As setas coloridas indicam a dinâmica em potencial dentro de uma perspectiva desenvolvimentista: vermelha (interações do desenvolvimento), azuis (interações transacionais) e verdes (interações epigenéticas). $\mathrm{PGP}=$ potencializadores poligênicos; Endoph. $=$ endofenótipo.
} 
psicocomportamental levam em consideração, não apenas amostras de indivíduos com pontuações altas nos testes, mas também amostras de indivíduos com pontuações baixas (Barrantes-Vidal et al. 2015). Na medida em que esse construto reflete um conjunto de traços de personalidade consideravelmente estáveis por todo seu contínuo, a esquizotipia se estende dos domínios da psicologia aos da psiquiatria, tornando os estudos sobre sua variação importantes do ponto de vista do desenvolvimento (ou não) de transtornos associados ao fenótipo do espectro da esquizofrenia (Barrantes-Vidal et al., 2015; Ettinger et al., 2014).

Enfim, vale salientar que como não há um correlato perfeito entre as medidas psicométricas e a realidade psicológica, pode acontecer de indivíduos obterem pontuações elevadas por razões não relacionadas aquilo que o instrumento mede; ou seja, um falso positivo (Lenzenweger, 2015).

Estudos que investigam o impacto de fatores relacionados à estrutura e funções cerebrais nas diferentes manifestações da esquizofrenia sugerem que diferenças morfológicas, bem como diferenças na lateralização de funções (possivelmente perdidas ou revertidas nas psicoses) estão relacionadas aos diferentes sintomas e expressões do transtorno (Crow, 2010). Nesse contexto, pesquisas que buscam correlacionar estruturas e áreas cerebrais envolvidas na psicose têm na esquizotipia um aliado nos estudos comparativos, na medida em que esse construto caracteriza um grupo de indivíduos não clínicos (que não manifestam psicose), mas cuja estrutura cerebral hipoteticamente se assemelha a de esquizofrênicos.

Buchsbaum et al. (1998) avaliaram, com uso de ressonância magnética, o volume ventricular e a assimetria cerebral em pacientes com transtorno de personalidade esquizotipia (TPE), pacientes esquizofrênicos e um grupo controle normal. Os resultados sugerem que as características estruturais do cérebro de pacientes com TPE apresentam, em menor grau, as mesmas anormalidades de esquizofrênicos. Concluíram, portanto, que a diminuição de volume no hemisfério esquerdo, verificadas nas regiões frontal e temporal de indivíduos com esquizofrenia e de indivíduos com TPE, pode ser característico tanto de transtornos psicóticos como de não psicóticos. Dickey et al. (1999) investigaram, também com uso de ressonância magnética, possíveis anormalidades no volume de matéria cinzenta no lobo temporal - anormalidade comum em esquizofrênicos - em indivíduos com TPE. Os resultados mostram que esse indivíduos apresentam 
redução de volume GTS esquerdo, similar à redução de volume encontrada em pacientes esquizofrênicos. Os autores tomam esses parâmetros como evidência para a hipótese de que anormalidades no GTS podem fazer parte das anormalidades encontradas dentro do espectro endofenótipo da esquizofrenia/esquizotipia. Siever \& Davis (2004) sugerem que déficits no lobo temporal lateral existem tanto no TPE quanto na esquizofrenia, mas são compensados por uma maior capacidade frontal na esquizotipia. Durante a compreensão de comentários irônicos, indivíduos com alta esquizotipia apresentam redução na atividade bilateral temporal, mas aumento de ativação préfrontal esquerda. Estudos com ressonância magnética funcional também sugerem que a lateralização da linguagem é reduzida na esquizotipia (Ettinger et al., 2015).

Vale observar ainda que apesar de vários estudos sugerirem o comprometimento de ToM (Teoria da mente) na esquizofrenia (Brüne \& Bodenstein, 2005; Corcoran et al., 1995; Craig et al., 2004; Herold et al., 2002; Langdon et al., 2002; Pickup and Frith, 2001; Sarfati et al., 1999) ${ }^{7}$, não é claro que este comprometimento ocorra na esquizotipia (McCleery et al., 2012; Tonelli et al., 2009). ToM é uma habilidade cognitiva que se traduz na capacidade de se fazer inferências sobre pensamentos, sentimentos e intenções alheias que, pode estar relacionada à linguagem, na medida em que o desenvolvimento de ToM parece ser paralelo ao domínio de estruturas sintáticas complexas envolvendo auto-encaixamento sentencial de segunda ordem (de Villers, 2000; Hale \& TagerFlusberg, 2003, entre outros). Champagne-Lavau et al. (2009) verificou que esquizofrênicos têm dificuldade para marcar informação usada (artigos definido informação conhecida - e artigo indefinido - informação nova), bem como têm problemas no uso de informação compartilhada com o experimentador ${ }^{8}$. Tais estudos sugerem um possível comprometimento de ToM na etiologia e na manutenção de sintomas psicóticos, como por exemplo, a fala desorganizada. Contudo, McCleery et al. (2012) observaram que, indivíduos com pontuações altas em escalas de esquizotipia ${ }^{9}$ não tiveram problemas para compreender

\footnotetext{
${ }^{7} \mathrm{O}$ mesmo não se pode afirmar de esquizotípicos avaliados com instrumentos psicométricos (McCleery et al., 2012; Tonelli et al., 2009)

${ }^{8}$ Observe, no entanto, que o desenvolvimento ToM é geralmente correlacionado com fatores estruturais da gramática, em especial, a capacidade de produzir e compreender estruturas com auto-encaixamento sentencial.

${ }^{9} \mathrm{Um}$ possível reflexo de traços positivos, negativos e desorganizados deste construto de personalidade.
} 
sarcasmo, bem como aumentaram sua performance em tarefas de ToM envolvendo percepção de ironia. Tonelli et al. (2009), em uma revisão da literatura sobre alterações de ToM em indivíduos esquizotípicos ou portadores de sintomas psicóticos subsindrômicos, também concluem que os dados coletados até agora se auto contradizem.

Assim, a pesquisa que aqui apresentamos volta-se para a questão da construção da referencialidade em esquizopia sem, no entanto, entrar na questão de indivíduos psicometricamente esquizotípicos apresentarem ou não dificuldades com ToM. Uma investigação a esse respeito seria mais relevante para estudos com foco na complexidade sintática (e.g. auto-encaixamento) no espectro da esquizotipia.

É importante salientar que, apesar de ser um fator de risco para transtornos do espectro da esquizofrenia, poucas pessoas com alto resultado nas escalas de esquizotipia tornam-se clinicamente doentes. Grant (2015), por exemplo, salienta que todos os esquizofrênicos são altamente esquizotípicos, mas que nem todos os indivíduos altamente esquizotípicos são esquizofrênicos. $\mathrm{O}$ desenvolvimento da esquizotipia em esquizofrenia depende de variações e influências de fatores biológicos e estímulos externos.

\section{3.}

\section{Linguagem no espectro da esquizofrenia}

O padrão de comprometimento da linguagem em esquizofrênicos apresenta notadamente problemas no que tange à construção do significado, especialmente à construção da referencialidade e à organização discursiva. Por isso, a esquizofrenia é considerada uma logopatia (Radanovic et al., 2013).

Uma das primeiras classificações consistentes, e a mais usada até hoje, a respeito da linguagem em esquizofrenia foi elabora por Andreasen (1979), que descreveu claramente os distúrbios de linguagem observados em pacientes, criando um conjunto de definições usado como padrão no diagnóstico da doença $^{10}$.

Andreasen observa que não podemos inferir que distúrbios da fala sejam reflexo de disfunções do pensamento. Assim, a autora argumenta que o termo

\footnotetext{
${ }^{10}$ A classificação de Andreasen foi inserida na $3^{\mathrm{a}}$. edição do Manual de Diagnóstico de Desordens Mentais.
} 
"fala desorganizada" deveria substituir "desordem do pensamento formal", pois é isso que pode ser observado, e de fato medido.

Apesar da FTD ser entendida como um único fenômeno, na verdade, ela se manifesta em diferentes comprometimentos da linguagem. Andreasen (1979) descreveu 18 tipos de manifestações de distúrbios de fala e propôs uma escala de avaliação que chamou de Thought, Language and Communication (TLC). Os 18 tipos de desordens presentes na fala de esquizofrênicos conforme a definição dada por Andreasen podem ser verificados no exemplos abaixo ${ }^{11}$.

(1) Pobreza do discurso ou da fala (fala lacônica): a fala espontânea é curta e breve, com respostas concretas e sem elaboração.

Entrevistador: Você pode me dizer alguma coisa sobre o que o trouxe ao hospital?

Sujeito: $\quad$ Um carro.

Entrevistador: Eu estava pensando no tipo de problema que você está enfrentando. Pode me falar um pouco sobre isso?

Sujeito: $\quad$ Não sei.

(2) Pobreza de conteúdo: fala imprecisa e prolixa que apesar da quantidade adequada, não diz nada. A linguagem tende a ser vaga, frequentemente excessivamente abstrata ou excessivamente concreta, repetitiva e estereotipada.

Entrevistador: Por que você acha que as pessoas acreditam em Deus?

Sujeito: $\quad$ Bem, em primeiro lugar, por que Ele, hã, Ele é a pessoa que é o seu salvador pessoal. Ele anda comigo e conversa comigo. E, há, o entendimento que eu tenho, hum, muitas pessoas, elas não

\footnotetext{
${ }^{11} \mathrm{O}$ exemplos são todos de Andreasen (1979). Contudo, a tradução dos exemplos em 1, 2, 4, 5, 7, 9, 10,14, 15 e 17 foram retiradas da edição em português de Andreasen e Black (2009: 55-61), enquanto a tradução dos exemplos em 12,13, 16 e 18 foram feitas por mim, diretamente de Andreasen, 1979. Não foram encontrados exemplos de Andreasen referentes aos itens 3, 6 e 8 .
} 
entendem, hum, de cara quem elas são. Porque, hã, elas não sabem quem elas são. Elas não, elas não sabem que Ele, hã - pra mim parece que, muitas delas não entendem que Ele anda e fala com elas.

(3) Aceleração da fala: aumento da quantidade da fala espontânea, que fica muito rápida e difícil de ser interrompida.

(4) Discurso digressivo (ou fala distrativa): mudança no rumo da fala causada por estimulo do ambiente externos.

Sujeito: $\quad$ Então eu saí de San Francisco e me mudei para... onde você arranjou essa gravata? Parece uma sobra dos anos 50! Eu gosto do clima quente de San Diego. É uma concha do mar que você tem em cima da mesa? Você já praticou mergulho?

(5) Tangencialidade: respostas obliquas, tangenciais ou irrelevantes, não relacionadas ao assunto de uma pergunta.

Entrevistador: De que cidade você é?

Sujeito: Bem, essa é uma pergunta difícil de responder, porque meus pais... Eu nasci no estado de Iowa, mas sei que sou branco e não negro, então aparentemente eu vim de algum lugar do norte, e não sei de onde. Sabe, eu realmente não sei se sou irlandês ou escandinavo, ou não. Não acredito que seja polonês, mas acho que sou, acho que talvez eu possa ser alemão ou galês.

(6) Perda de objetivo: fala que se desvia do assunto, não consegue manter o fluxo dos pensamentos até sua conclusão. Normalmente começa falando de determinado assunto, se perde no processo e nunca 
consegue voltar de onde se perdeu. Pode estar associada ao descarrilamento.

(7) Descarrilamento: ideias que fogem do assunto de uma conversa, mas são parcialmente relacionas a ele; ocorre no nível do discurso.

Entrevistador: Você gostou do tempo que passou na faculdade?

Sujeito: Hum-hum. Ah, bom, eu, é, eu gostava muito de alguns grupos. Eu tentei, e no, e no dia seguinte quando eu ia sair, sabe, hum, eu assumi o controle, tipo, hum, eu coloquei, ah, água sanitária no cabelo na, na Califórnia. A minha companheira de quarto era de Chicago, e ela estava na faculdade. E nós morávamos na YWCA, então ela queria colocar, hum, água oxigenada no meu cabelo, e colocou, e eu levantei e me olhei no espelho e meus olhos se encheram de lágrimas. Agora, você entende - eu estava totalmente ciente do que estava acontecendo, mas por que eu não conseguia, eu... por que as lágrimas? Eu não consigo entender, você consegue?

(8) Circunstancialidade: padrão de fala indireta retardada e cheia de detalhes tediosos. Consegue, depois de muito detalhamento, chegar ao objetivo.

(9) Ilogicidade: inferências injustificadas e ilógicas entre cláusulas.

Sujeito: $\quad$ Os pais são pessoas que criam você. Qualquer coisa que cria você pode ser um pai. Pais podem ser qualquer coisa - material, vegetal ou mineral - que lhe ensinou alguma coisa. Os pais são o mundo de coisas que estão vivas, que estão por aí. Pedras uma pessoa pode olhar para uma pedra e aprender alguma coisa com ela, então ela seria um pai. 
(10) Incoerência (salada de palavras, esquizofasia): fala incompreensível que pode ser acompanhada por descarrilamento, mas difere deste porque aqui a anormalidade está no nível da sentença ou frase.

Entrevistador: O que você pensa sobre questões políticas atuais, como a crise energética?

Paciente: $\quad$ Eles estão destruindo muito gado e petróleo apenas para fazer sabão. Se precisarmos de sabão quando você pode pular em uma poça d'água, então quando você vai comprar gasolina, os meus pais sempre acharam que deviam comprar refrigerante, mas a melhor coisa para comprar é óleo para motor e dinheiro. Pode, pode ser, dá pra ir lá e trocar, algumas tampinhas de refrigerante e, ah, pneus, e tratores para rebocar, garagens de carros, para eles separarem os carros bons da sucata, é nisso que eu acreditava.

(11) Neologismos: invenção de palavras cuja derivação não segue as regras da língua, tornando-a incompreensível.

Sujeito:

Fiquei tão zangado que peguei um prato e joguei no "genshinker". (termo original)

(12) Palavras aproximadas: palavras velhas usadas de maneira pouco convencional, ou palavras inventadas que fazem sentido, por exemplo, um relógio pode ser chamado de "capsula do tempo", ou o estômago pode ser chamado de "capsula de alimento".

(13) Discurso pretencioso: fala pomposa, de estilo excessivamente formal. 
Sujeito: $\quad$ Com licença, madame, eu gostaria de solicitar uma conferência com a senhora em seu consultório quando melhor lhe convir?

(14) Reverberação: associações sonoras (clanging), as palavras são associadas pela sonoridade.

Sujeito: $\quad$ Eu não estou tentando fazer barulho. Estou tentando fazer sentido. Se você for capaz de fazer sentido sendo sensível, então sinta-se em casa. Eu estou tentando fazer sentido sem sentido. Não faço sentidos nem centavos; eu faço dólares.

(15) Perseveração: repetição persistente de palavras, ideias, expressões ou assuntos.

Entrevistador: Fale-me a seu respeito: que tipo de pessoa você é? Sujeito: $\quad$ Eu sou de Masshalltown. Fica a 60 milhas ao noroeste, nordeste de Des Moines, Iowa. Sou casado no momento. Tenho 36 anos. Minha mulher tem 35 anos. Ela mora em Garwin, Iowa. Fica a 15 milhas ao sudeste de Marshalltown, Iowa. Estou me divorciando no momento. E no momento estou em uma instituição psiquiátrica em Iowa City, que fica a 100 milhas a sudeste de Marshalltown, Iowa.

(16) Ecolalia: o paciente ecoa palavras ou frases do entrevistador, muitas vezes com entonação zombeteira.

Entrevistador: Eu gostaria de falar com você por uns minutos. Sujeito: $\quad$ Falar com você por uns minutos.

(17) Bloqueio: interrupção da fala antes de expressar o pensamento ou ideia. 
Sujeito: $\quad$ Então eu não queria voltar a estudar, então eu... (1minuto de silêncio enquanto o paciente fica com os olhos fixos no vazio)

Entrevistador: E quanto à volta aos estudos? O que aconteceu?

Sujeito: $\quad$ Não sei. Esqueci o que ia dizer.

(18) Auto referência: paciente fala excessivamente sobre si mesmo.

Entrevistador: Que horas são?

Sujeito: $\quad$ Sete horas. Esse é meu problema. Nunca seu que horas são. Talvez eu devesse tentar saber sempre que horas são.

Vale salientar que Andreasen e Black (2009) inclui descarrilamento, tangencialidade, incoerência, ilogicidade, circunstancialidade, aceleração da fala, fala distrativa e reverberação como sintomas de FTD positiva. Enquanto pobreza da fala, pobreza do discurso, bloqueio, perseveração estão entre os sintomas presentes na fala de pacientes com FTD negativa.

Kuperberg (2010a) salienta que descarrilamento e tangencialidade são manifestações da FTD positiva fortemente identificadas com as "associações soltas" observadas na falta de relação entre palavras e o contexto geral do discurso. No nível da sentença, a FTD positiva se manifesta por meio de neologismos ou pelo uso de palavras comuns de maneira bizarra ou idiossincrática. A FTD negativa, por sua vez, se verifica na pobreza do discurso, na pobreza do conteúdo da fala, bem como no bloqueio (manifestações relacionadas à alogia).

Apesar de esses sintomas compreendem uma gama de disfunções distintas sem nenhum tipo de traços essencialmente centrais (Convington 2005), Andreasen e Grove (1986) encontraram dois fatores principais na FTD: desorganização fluente (aceleração da fala, discurso digressivo, descarrilamento, perda de objetivo e perseveração) e desorganização vazia (pobreza do discurso e pobreza de conteúdo). 
Chen (1996), observando estudos da psicolinguística, levou em consideração os níveis de organização da estrutura linguística ao elaborar uma escala com 17 sintomas. A escala de avaliação de linguagem clínica (CLANG Clinical Language Disorder Rating Scale) propõe três grandes tipos de disfunções em pacientes esquizofrênicos: sintáticas, semânticas e de produção. As disfunções sintáticas afetam a estrutura da linguagem em todos os níveis, incluindo o acesso lexical. As semânticas afetam a habilidade de mapear o pensamento em linguagem com objetivo comunicativo (sentido tradicional de FTD). As disfunções de produção estão associadas aos sintomas negativos da esquizofrenia.

Nota-se, portanto, que os distúrbios de linguagem foram descritos por diferentes autores, e as anomalias encontradas são divididas sob diferentes perspectivas.

Referência importante a nossa pesquisa, é o índice de avaliação específico para falhas de comunicação baseadas na referencialidade, elaborado por Docherty et al. (1996) (Communication Disturbances Index - CDI). Este índice inclui as seguintes categorias para distúrbios que causam falhas de comunicação: referências vagas; referências confusas, falta de informação sobre as referências; palavras de sentido ambíguo; erro na escolha da palavra da referência; falta de clareza estrutural. Docherty et al. (1999: 854) fornece os seguintes exemplos de distúrbios de referência:

(1) Referência confusa: uso de uma referência para a qual há mais de um referente possível e a escolha correta não é clara.

Sujeito: $\quad$ He stabbed the dude and I kicked him. I thought he punched him. I thought he was on the ground just acting like he was hurt.

Sujeito: $\quad$ The supervisor was so jealous because bosses liked me because I was a very good and hard worker, that they didn't like that...

(2) Falta de informação da referência: uso de uma referência para qual não há informação prévia, ou informação desconhecida para o ouvinte. 
Sujeito: I designed the first rockets, and the cars and the boats. (não houve nenhuma menção anterior a carros ou barcos)

(3) Palavra de sentido ambíguo: Uma palavra ou frase com mais de um sentido, usada de forma que seu sentido não fica claro.

Sujeito: $\quad$ I'm all natural and I don't hang in crowds.

(4) Falta de clareza gramatical: Uma expressão cujo sentido não é claro devido a violações de regras estruturais da língua.

Sujeito: $\quad$ They had keeping a babysitter that studied but a Siamese cat that had ringworm.

Sujeito: I was socializing with friends. Girlfriends and friends the same as male

(5) Referência vaga: Uma palavra ou expressão que não é clara por falta de especificidade.

Sujeito: $\quad$ We had to go to court and other bad things.

(6) Uso de palavra errada na referência: Uma escolha errada de palavra ou expressão que leva a um significado incerto.

Sujeito: He was doing well in the beginning, but then he sort of abused his study habits.

Docherty et al. (2000) sugere que este tipo de problema com referencialidade semântica pode indicar comprometimento na capacidade de sequenciamento conceitual; isto é, na habilidade de organizar conceitos simples em sequências de conceitos mais complexos. Dado que esse sequenciamento se dá 
no âmbito da linguagem, o sequenciamento de conceitos e ideias está relacionado à estrutura da linguagem.

Voltaremos, no capítulo 3, a discutir esta questão no âmbito de expressões nominais definidas e pronomes.

Anormalidades linguísticas estão também presentes na esquizotipia, especialmente, no processamento de estruturas de alta ordem ${ }^{12}$. Indivíduos com alta esquizotipia apresentam déficits na produção e interpretação de linguagem não literal, como por exemplo a metáfora, similares às observadas na esquizofrenia. Por outro lado, a associação com a esquizotipia é sutil e vários mecanismos podem contribuir para os déficits encontrados, incluindo associações semânticas incomuns, mecanismos de priming semântico bizarros, e a integração inadequada de contexto (Ettinger et al., 2015).

\section{4}

\section{Hipótese evolutiva sobre a relação entre linguagem e esquizofrenia}

Crow (1998b, 2000, 2004b, 2008) levanta a hipótese de que a esquizofrenia é um transtorno que evolutivamente está diretamente ligado à capacidade biológica para adquirir linguagem, pressupondo que esquizofrenia e linguagem são frutos do mesmo evento que separou o homo sapiens do hominídeo anterior ${ }^{13}$. Este evento teria sido o responsável pela assimetria entre os hemisférios cerebrais, e a consequente restruturação neuronal associada à especialização hemisférica observada nos seres humanos.

$\mathrm{Na}$ visão de Crow, a linguagem surgiu como resultado da mudança genética que permitiu aos hemisférios certa independência de desenvolvimento. Essa mudança favoreceu a especialização dos hemisférios, tornando o hemisfério esquerdo dominante em relação ao outro, e a consequente segregação de componentes funcionais da linguagem no lado esquerdo. Essa dominância teria causado, assim, diferenças na distribuição das conexões entre hemisférios nos dois lados, permitindo um espalhamento da atividade neural sistematicamente diferente de um lado comparado ao outro. Contudo, a direção desse espalhamento é contraria nas metades motora e sensorial, convergindo da direita para esquerda

\footnotetext{
${ }^{12}$ Estruturas de alta ordem são formadas no nível do discurso e são constituídas pelo significado proposicional transmitido pelas sentenças (Kuperberg \& Caplan, 2003).

${ }^{13}$ Segundo hipótese de Crow, a mesma mutação genética, possivelmente relacionada a um único gene regulador da dominância cerebral, possibilitou o surgimento da linguagem e da psicose. Ver Brüne (2004) sobre esta e hipóteses sobre o enigma evolucionário da esquizofrenia.
} 
anterior, e da esquerda para a direita posterior (ver figura 2).

Figura 2.

Transmissão da informação entre áreas assimetricamente distribuídas do córtex humano (Crow, 2008: 38).

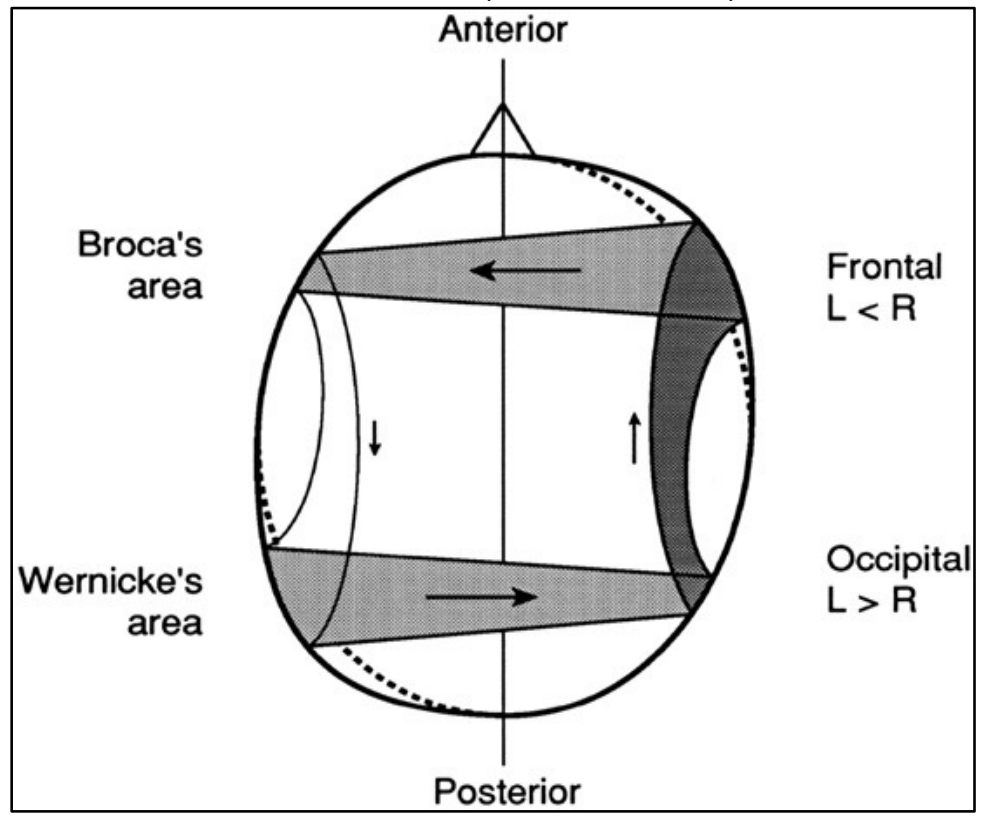

Para Crow (Honea et al., 2005), as convergências da esquerda posterior para a direita posterior e da direita anterior para a esquerda anterior podem ser associadas, respectivamente, à geração de sentido a partir de enunciados vindos de uma fonte externa - proferidos por outros ou pela própria pessoa - e a partir de pensamentos e intensões de fala. Assim, na medida em que a linguagem é entendida a partir da segregação de funções entre os hemisférios, os sintomas da psicose salientam possíveis falhas nessa segregação. Mais especificamente, para Crow, falhas na transição do pensamento para a produção e ativação da fala são manifestas em delírios e alucinações, e resultam de ativação imprópria de instruções fonológicas relacionadas à percepção da fala no hemisfério dominante.

Ainda dentro da hipótese de Crow, a referência dêitica, ou enquadramento dêitico da referência (sistema de coordenadas que relaciona o output fonológico ao "eu" do falante, ao momento presente (o "agora") 14 , e a localização do falante no tempo e no espaço (o "aqui" e "agora"), observada na comunicação humana reflete à distinção entre o que é sensorial e o que é motor na representação neuronal (Crow, 2004b). Isto é, a referência dêitica reflete o fluxo de transmissão

\footnotetext{
${ }^{14}$ Ver Buehler (1934) para mais detalhes.
} 
de informação entre os componentes funcionais da linguagem no córtex sensorial e motor. Assim, os sintomas nucleares da esquizofrenia ${ }^{15}$ são entendidos como uma quebra no sistema de referencialidade dêitica do indivíduo. Isso significa que quando uma falha anatômica funcional ocorre na diferenciação hemisférica do indivíduo, os sintomas nucleares da esquizofrenia podem surgir, causando a perda de distinções básicas do sistema de referência dêitica da comunicação ${ }^{16}$.

\section{5}

\section{Conclusão parcial}

Neste capítulo, apresentamos análises sobre a forma como o construto da esquizotipia e a esquizofrenia interagem. Apresentamos estudos que sugerem que ambos têm uma base genética diretamente relacionada à estrutura e ao funcionamento cerebral, principalmente, quanto as funções e os componentes da linguagem.

Dentre os sintomas centrais da esquizofrenia, a FTD, diretamente associada à fala, é o único que está presente, mesmo que de forma sutil, em indivíduos sem quadro clínico.

Pacientes com esquizofrenia produzem discurso menos coeso, falhando em fornecer referências adequadas e, com frequência, não codificam os participantes no contexto discursivo. Assim, esquizofrênicos em geral falham no estabelecimento de relações anafóricas entre referentes no âmbito do discurso, valendo-se de referências exofóricas (relacionadas a contextos externos) ou ambíguas para se comunicarem.

No próximo capítulo, discutiremos mais de perto a linguagem como processo cognitivo, em especial a relação entre linguagem e pensamento e a estruturação de referência conceitual.

\footnotetext{
${ }^{15}$ Crow foca nos elementos chave dos sintomas nucleares, conforme definição do Present State Examination - PSE (Wing et al. 1974): thought eco or commentary (item 57), voices commenting (item 62), passivity or delusions of control (item 71), thought insertion (item 55), thought withdrawal (item 58), thought broadcast (item 56) e primary delusions (item 82). Sintomas elaborados por Schneider (1948).

${ }^{16}$ Ver Crow (1998a) para uma explicação detalhada sobre os sintomas nucleares da esquizofrenia entendidos como consequência de disfunções relacionadas à lateralização hemisférica da linguagem e o sistema de símbolos dêiticos.
} 


\section{Linguagem \& Cognição}

Neste capítulo discutiremos duas visões diferentes sobre a arquitetura da linguagem (visão modular e visão não modular), bem como suas implicações para a relação entre linguagem e pensamento. Como o foco da presente pesquisa é a propriedade de referencialidade conceitual, em especial, a referencialidade de expressões nominais definidas ${ }^{1}$, discutiremos também questões semânticas e pragmáticas sobre referencialidade e definitude, buscando enfatizar questões sobre referencialidade em esquizotipia/esquizofrenia.

\section{1}

\section{Loquor, ergo sum!}

Estudiosos de diferentes áreas assumem que a linguagem é possivelmente o componente cognitivo (e biológico) que permitiu ao homo sapiens se diferenciar das outras espécies (Pinker \& Bloom, 1990; Carstairs-McCarthy, 2007; Bickerton, 2003; Power, 2009; Fitch, 2010; Bolhuis et al., 2014, Berwick \& Chomsky, 2015; entre outros). Uma das hipóteses é que ela tenha emergido de uma habilidade cognitiva computacional compartilhada pela espécie que se mantém basicamente inalterada desde seu surgimento há aproximadamente 100 mil anos (Berwick et al 2013, Bolhuis et al., 2014; Berwick \& Chomsky, 2015).

A linguagem é um sistema mental complexo que, como a visão e o sistema imunológico, têm princípios próprios, integridade interna e propriedades especiais (Chomsky, 2007). Portanto, a linguagem é, dentro da perspectiva da biolinguística, pensada como uma faculdade cognitiva única da espécie humana (Hauser, Chomsky \& Fitch, 2002; Fitch, 2010; Berwick \& Chomsky, 2015, entre outros)

Contudo, apesar dos esforços realizados dentro da própria linguística e em áreas afins, ainda não se tem uma compreensão exata de quais aspectos da linguagem são únicos da cognição humana, tampouco quais mecanismos da cognição humana são únicos da linguagem.

A faculdade da linguagem conforme definida por Hauser, Chomsky e Fitch (2002 - HCF) é um sistema inato especifico cujo o modo de operação, bem como

\footnotetext{
${ }^{1}$ Aquilo que uma expressão nominal definida denota.
} 
o curso de seu desenvolvimento são distintos. Logo, é um sistema cognitivo de domínio específico, que evoluiu de forma independente e, sobretudo, usa informações específicas com fins específicos.

Como ilustra a figura 3, a faculdade da linguagem somada aos sistemas cognitivos externos com os quais se comunica é chamada de faculdade da linguagem no sentido amplo (faculty of language broad sense - FLB) e é composta por módulos que são encontrados em outras espécies ${ }^{2}$. A faculdade da linguagem no sentido estrito (faculty of language narrow sense - FLN, ou gramática) compreende apenas o sistema combinatorial da linguagem, cuja função central é a geração de representações linguísticas recursivas. A FLN só é encontrada no homo sapiens e, por isso, corresponde a processos combinatoriais que ocorrem unicamente em humanos e são específicos da linguagem. Por outro lado, a FLB corresponde a processos que são compartilhados entre diferentes espécies e, portanto, estão envolvidos na linguagem e em outros processos mentais (Berwick, 2013; Bolhuis et al., 2014; Hauser et al. 2014; Berwick \& Chomsky, 2015).

Figura 3.

Modulo da linguagem - Hauser, Chomsky e Fitch (2002:1570)

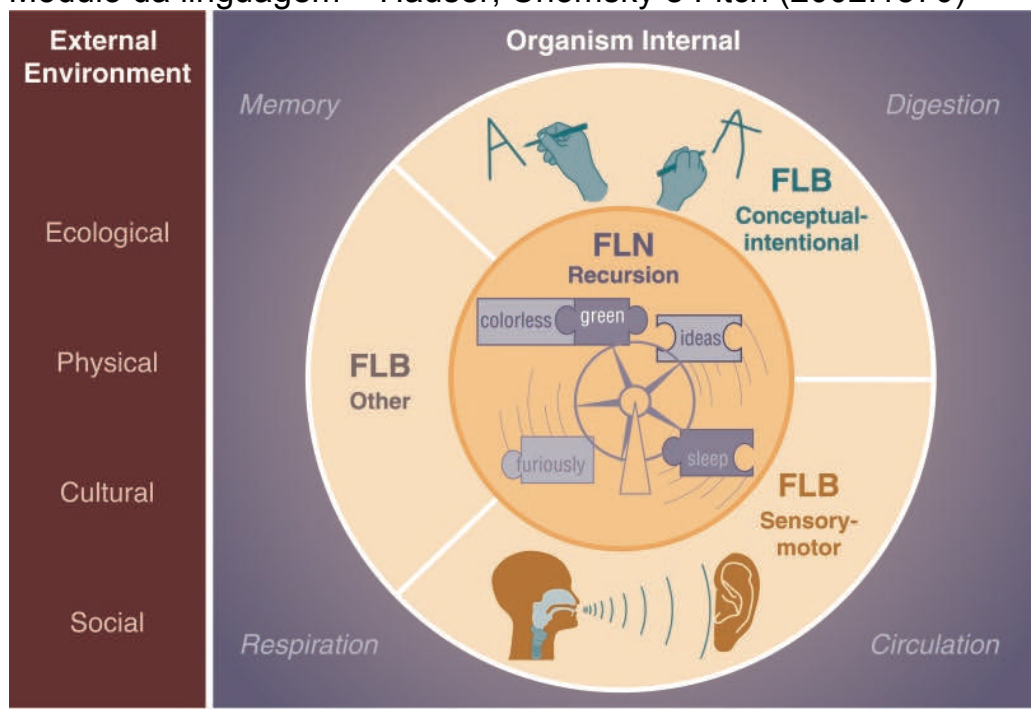

Assim, FLN/gramática é fundamentada em um mecanismo combinatorial único. Esse mecanismo precisa, minimamente, combinar conceitos linguísticos (eg. [beber $]_{\text {verbo }}$ e $[\text { suco }]_{\text {nome }}$ ) de forma a gerar objetos linguísticos mais complexos (e.g. [beber suco $]_{\text {predicado verbal). }}$

\footnotetext{
${ }^{2}$ Para uma teoria detalhada sobre a mente como sistema modular, ver Fodor (1983).
} 


\section{2}

\section{A arquitetura da mente: teorias sobre a relação entre linguagem e pensamento}

Como discutimos acima, numa perspectiva biológica, linguagem é uma função cognitiva única do homo sapiens. Dentro dessa abordagem, existem pelo menos duas posições para se pensar a arquitetura da cognição e, consequentemente, a relação entre pensamento e linguagem. De um lado, a visão Cartesiana desenvolvida por Chomsky (2009), que redimensiona conceitos utilizados na tradição Racionalista, e os integra a uma perspectiva investigativa biológica da linguagem. Nessa visão, a linguagem é um módulo da cognição humana em interfaces com outros módulos (Figura 4). São as interfaces, especialmente aquelas com os sistemas sensório-motor (S-M) e conceptualintencional (C-I), que definem a legibilidade das representações linguísticas geradas pela gramática. Para se compreender a relação dos sistemas S-M e C-I com a linguagem basta pensarmos que esses são sistemas que lidam com som e significado, respectivamente. Assim, sendo a gramática um sistema gerador de pares de som e significado, é preciso pressupor a existência de interfaces entre a gramática (FLN) e outras partes da cognição que lidam com som e significado.

Figura 4.

A gramática e suas interfaces (Berwick et al, 2013: 91)

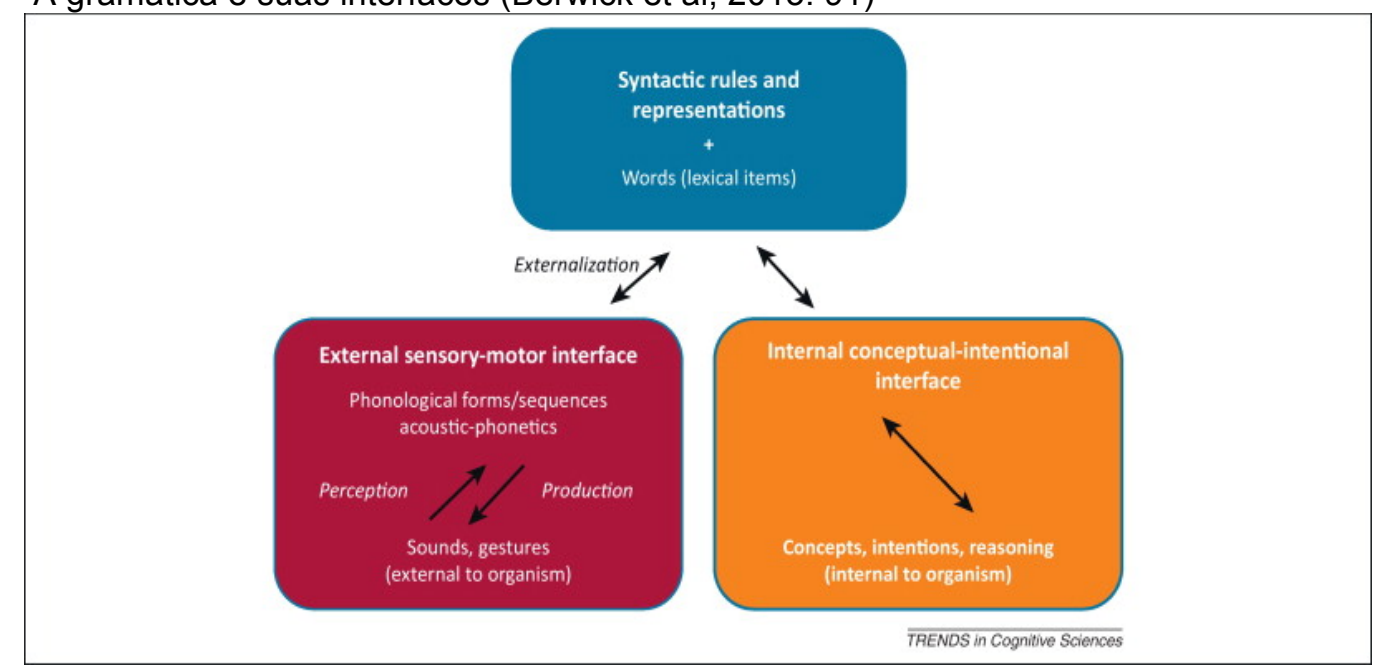

Desse modo, como a interpretação semântica de uma expressão linguística complexa envolve a interpretação de suas partes (Princípio da Composicionalidade - Frege, 1892; Pelletier \& Jeffrey, 2001). Cabe à gramática 
tecer a representação linguística de modo que o significado do todo seja gerado a partir do significado das partes, mas cabe ao sistema C-I atribuir referência (denotações de indivíduos e valores de verdades) ${ }^{3}$ às representações estruturadas pela gramática. Assim, na visão chomskyniana da linguagem, os sistemas de pensamento, por meio de interfaces, impõem restrições à legibilidade das representações linguísticas. No entanto, parte-se do pressuposto, embora não sem argumentação, mas sem nos fornecer uma definição formal do que venha a ser o pensamento, de que linguagem e pensamento não são exatamente a mesma coisa.

"O surgimento na história da evolução da humanidade da operação Merge ilimitada fornece o que tem sido chamado de "linguagem do pensamento", um sistema gerativo interno que constrói pensamentos arbitrariamente ricos e complexos, explorando recursos conceituais previamente disponíveis" (Chomsky, 2007: 22) (Tradução minha).

A pressuposição é de que linguagem e pensamento sejam ambos sistemas combinatoriais, embora distintos. Nesse sentido, Chomsky aproxima-se da visão de Fodor $(1975,1983)$ sobre a organização da mente humana e a estruturação do pensamento ${ }^{4}$.

Em contraposição a essa visão modular da mente, Hinzen (2014) propõem uma visão não-cartesiana (Un-cartesian Linguistics) ${ }^{5}$. Nessa visão, a gramática é o motor gerador do pensamento conceitual. A gramática é ela mesma a geradora do sentido, sendo responsável por impor restrições estruturais às representações que determinam suas referências. Não há, assim, interfaces entre linguagem e sistemas de pensamento, porque pensamento e linguagem (i.e. gramática) são uma mesma coisa. Ou seja, na visão não-cartesiana de Hinzen, a nossa cognição, em especial a parte dela responsável pelo pensamento, é reflexo dos processos gramaticais subjacentes às línguas.

Hinzen $(2007,2012,2014,2015)$ propõe que o pensamento tipicamente humano (i.e. encontrado apenas no homo sapiens) é uma forma peculiar de pensamento linguístico, isto é um conjunto de processos mentais intermediados

\footnotetext{
${ }^{3}$ Ver Heim and Kratzer (1998)

${ }^{4} \mathrm{Na}$ hipótese de Fodor sobre linguagem do pensamento (LOT - Language of Thought, ou mentalese), o pensamento emerge de mecanismos estruturantes semelhantes aos das línguas naturais. Portanto, pensamentos também são representações estruturadas, no entanto, Fodor não reduz LOT à linguagem. Para ele, esses são mecanismos cognitivos distintos. Em contraste, Hinzen os entende como sendo o mesmo mecanismo.

${ }^{5}$ Para uma resenha crítica da hipótese de Un-cartesiana ver Boeckx (2015).
} 
pela gramática. Este tipo de pensamento é definido pelo autor como sendo conceitual (ao invés de perceptual), intencional e intensional, referencial e proposicional, e arbitrariamente criativo dentro dos limites impostos pela gramática. Assim, para Hinzen, o pensamento é restringido pelos processos combinatoriais mecânicos internos à gramática. Ou seja, do ponto de vista conceptual, os seres humanos concebem apenas pensamentos que podem ser gerados pelas operações do sistema computacional da linguagem.

Em resumo, a questão central que se apresenta diante desses dois entendimentos é sobre a relação entre a gramática e o pensamento conceitual. Dentro da corrente cartesiana, as condições de boa formação de uma representação linguística são determinadas nas interfaces da gramática/FLN com outros sistemas da mente. Daí, linguagem e pensamento não são tomados como sendo faces diferentes da mesma moeda, mas como sistemas que se comunicam por meio de interfaces. Hinzen $(2007,2012)$, por outro lado, argumenta que as condições de boa formação sobre representações linguísticas resultam da mecânica da gramática. Assim, definindo pensamento como um conjunto de processos relacionados à gramaticalização de conceitos, Hinzen parte da hipótese de que esses dois aspectos da cognição humana são, em realidade, a cara e a coroa de um único sistema.

Como tratam-se de questões abstratas sobre a arquitetura da cognição, decidir entre uma proposta e outra não é tarefa fácil e somente observações empíricas sobre os processos de aquisição, perda e disfunções da linguagem e do pensamento podem nos indicar qual destas propostas é a mais produtiva. É nesta direção que avança Hinzen ao oferecer, como evidência para uma unificação entre linguagem e pensamento, questões relativas às desordens mentais, como a esquizofrenia, definida por ele como a manifestação de uma quebra na estrutura linguística do pensamento.

\section{3}

\section{Referencialidade}

Como já acentuado no decorrer da dissertação, estamos interessados em entender questões de referencialidade linguística no construto da esquizotipia. Em especial, nos perguntamos se traços da personalidade esquizotípica podem interferir na construção da referência para descrições definidas (i.e. expressões 
nominais definidas). Desse modo, o foco desta seção fica restrito à referencialidade de expressões nominais ${ }^{6}$.

Entende-se que expressões nominais definidas encabeçadas pelo artigo “o/a" são definidas, ao passo que expressões nominais encabeçadas pelo artigo "um/uma" são indefinidas. Considere-se como exemplo as sentenças em (1). (1a) deve ser parafraseado como (2a), e (1b) como (2b). Isto é, tanto expressões nominais definidas como indefinidas pressupõem a existência de uma entidade que satisfaça a descrição fornecida pelo sintagma nominal ("diretor da Petrobrás"). No entanto, expressões nominais definidas, em contraste com expressões indefinidas, obedecem à restrição de unicidade: existe uma e apenas uma entidade que satisfaz a descrição fornecida pelo sintagma nominal (Russell, 1905; Strawson, 1950; Clark, 1975; Kadmon, 1990; Abott, 2006).

(1) a. Eu encontrei o diretor da Petrobrás na Polícia Federal.

b. Eu encontrei um diretor da Petrobrás na Polícia Federal.

(2) a. Existe um, e apenas um, diretor da Petrobrás, e eu o encontrei na Polícia Federal.

b. Existe pelo menos um diretor da Petrobrás e eu o encontrei na Polícia Federal.

A condição de Unicidade vem sendo repensada já que expressões nominais definidas no plural se referem não a um indivíduo, mas a um conjunto de indivíduos que satisfazem a denotação do sintagma nominal, como em (3). Por essa razão, Kadmon (1990) propõe substituir unicidade por maximalidade: expressões nominais definidas se referem ao conjunto máximo de indivíduos que satisfazem a descrição dada.

\footnotetext{
${ }^{6}$ Retratamos também que, dado o caráter interdisciplinar desta dissertação, optamos por discutir questões de referencialidade nominal de modo a evitar um aparato teórico formal complexo. Por exemplo, não abordaremos aqui a denotação de artigos/determinantes. Partimos do pressuposto que descrições definidas denotam indivíduos, mas não entramos em detalhes sobre a denotação dos elementos que a compõem (sobre isso, ver Barwise \& Cooper, 1981; Heim, 1982, Heim \& Kratzer, 1998, entre outros). Para uma caracterização mais ampla das condições impostas ao artigo definido, ver também Lyons (2004).

Nossa escolha de apresentação de um texto menos técnico foi para tentar garantir que leitores de diferentes áreas do conhecimento tenham entendimento do que estamos investigando e como estamos investigando.
} 
(3) Eu encontrei os diretores da Petrobrás na Polícia Federal.

Voltaremos à necessidade da condição de unicidade quando analisarmos diferenças importantes do português brasileiro (PB). No momento, considere-se que a condição em questão não é suficiente para descrevermos expressões definidas. Essas expressões pressupõem também familiaridade por parte dos interlocutores com a entidade referida pela expressão nominal. Por exemplo, podemos reagir adequadamente a sentença em (4) (e.g. atribuindo-lhe um valor de verdade - verdadeira ou falsa) apenas se identificamos o referente da expressão "o ex-governador do Rio de Janeiro". Como mais de uma entidade satisfaz a descrição "ex-governador do Rio de Janeiro", precisamos nos valer de informações/pistas fornecidas pelo contexto discursivo no qual a sentença está inserida para construirmos a referência da expressão. Isto é, uma expressão nominal definida obedece também a condição de familiaridade (Stalnaker, 1974; Heim 1982; Enç, 1991; Von Heusinger, 2002; Abbott, 2006): que restringe o uso dessas expressões a contextos (imediatos ou não) em que a existência do referente tenha sido previamente estabelecida.

(4) Eu vi o ex-governador do Rio de Janeiro sendo preso pela Polícia Federal

Por essa razão a introdução de uma entidade nova no discurso deve ser feita por meio de expressões nominais indefinidas (condição de novidade), enquanto referências a entidades que são familiares devem ser feitas por meio de expressões nominais definidas, como exemplificado em (5).

(5) A: Uma menina veio morar no meu prédio, e era uma menina muito bonita.

B: Não vai me dizer que a menina se apaixonou por você!

Em (5), o falante A introduz a expressão "uma menina" no discurso, o que garante a existência de uma entidade $x$ que satisfaz a descrição "menina". Portanto, o uso da expressão definida por B ancora-se na entidade introduzida por 
A. Em (5), temos um caso familiaridade forte (Heim, 1982), porque o referente foi explicitamente introduzido no discurso ${ }^{7}$.

Outra questão interessante que esses exemplos introduzem é sobre a referencialidade de expressões indefinidas. Se essas expressões não são referenciais (Russell, 1919), então em (5) a referência de "a menina" não pode estar ancorada na referência introduzida por A, simplesmente porque indefinidos ("uma menina") não referem. Heim (1982) recupera a noção de referente do falante de Kripke (1977) para lidar com essa questão. A ideia é que, ao introduzir expressões indefinidas, o falante tem algum referente em mente. Portanto, em (5) a expressão nominal definida de $\mathrm{B}$ refere-se a entidade de $\mathrm{A}$, ou seja a entidade que A tem em mente ${ }^{8}$.

Em resumo, expressões nominais definidas apresentam a condição de unicidade (ou maximalidade) e familiaridade. Se mais de uma entidade satisfizer a descrição do sintagma nominal ou se a referência da entidade não for compartilhada entre os interlocutores, poderá haver falha na comunicação. Esses casos de falha são geralmente entendidos como erros de pressuposição por parte do falante. Isto é, o ouvinte geralmente conclui que o falante está com uma pressuposição errada sobre o mundo ou sobre seu conhecimento do mundo. Em muitos casos, ocorre também acomodação por parte do ouvinte. Por exemplo, se alguém pronuncia algo como (6), um ouvinte, que conhece a cidade do Rio de Janeiro, irá imediatamente considerar que o falante não sabe que tem mais de um aeroporto no Rio de Janeiro, mas considerará também que provavelmente a intensão do falante foi referir-se ao aeroporto do Galeão, o mais conhecido e importante dos aeroportos do Rio.

(6) O aeroporto do Rio de Janeiro passou por uma reforma antes da Copa do Mundo.

Relevância é uma questão que deve ser considerada nesse contexto. A noção de relevância está relacionada à integração de informações necessárias à comunicação de um enunciado no momento da fala. A inferência de que o aeroporto mencionado em (6) é o Galeão é possível porque a circunstância

\footnotetext{
${ }^{7}$ Familiaridade fraca é quando o referente não é introduzido, mas está implícito no discurso.

${ }^{8}$ Ver também Donnellan (1997) and Kripke (1997) para a noção de "referente do falante".
} 
pragmática do enunciado faz o ouvinte acionar seus conhecimentos pessoais e de mundo para realizar a tarefa de compreensão. Da mesma forma, em (5) a inferência de que "a menina" em (B) refere-se à entidade denotada por "uma menina" em (A) só é possível na medida em que essa informação é a mais ostensivamente relevante para a construção da referência a tal entidade no contexto pragmático em questão. A Teoria da Relevância (TR) (Sperber \& Wilson, 1986/1995; 2010) é um modelo de comunicação e cognição que busca dar conta da característica da comunicação humana (Grice, 1957 e 1989) que diz respeito à expressão e ao reconhecimento de intensões. Nessa teoria assume-se que o reconhecimento de intensões é uma das caraterísticas principais da comunicação humana e que a busca pela relevância é uma propriedade básica da cognição humana que é ativada por expectativas geradas pelas próprias elocuções (Wilson \& Sperber, 2002 e 2005; Longchamps, 2014). Assim, pressupõe-se que o enunciado proferido pelo falante contém informações de caráter ostensivo suficientemente relevantes para desencadear no ouvinte os processos de inferência necessários ao ato comunicativo (Barin, 2001). No exemplo (6) acima, o input (i.e. o enunciado) precisa ser integrado ao conhecimento de mundo do indivíduo para que seja possível construir a referência ao Galeão. Enquanto no exemplo (5) é preciso integrar as informações fornecidas pelo discurso verbal para tal fim.

Observa-se, enfim, que a construção da referência de expressões nominais é um processo complexo de integração de informações semânticas e pragmáticas no qual informações/pistas fornecidas pelo contexto discursivo - verbal ou não verbal - são cruciais ao processo.

$\mathrm{O}$ PB, em contraste com o português europeu e outras línguas românicas, parece licenciar artigos definidos no singular com leitura de classe, sem obediência à condição de unicidade (Corrêa, Augusto \& Andrade-Silva, 2008; Longchamps, 2014; Ferreira \& Correia, 2016). Considere, por exemplo, a sentença em (7), na qual a expressão definida "o gato" refere-se à classe dos gatos, e não a um único indivíduo. Chamaremos essa leitura de leitura de classe, que aparece também com nomes nus no singular ou no plural (i.e. nomes não precedidos de artigo), como em (8) (kind reading - Carlson, 1977; Chierchia, 1995; Müller, 2002; Munn \& Schmitt, 2005; Dobrovie-Sorin \& Pires de Oliveira, 2008; Dayal, 2011). 
(7) O gato gosta de sardinha e o cachorro de salsicha.

(8) Gato/gatos gosta(m) de sardinha e cachorro/cachorros de salsicha.

Portanto, em PB expressões nominais definidas no singular licenciam leituras de classe e de indivíduo. Claramente, o licenciamento de leituras de expressões nominais definidas não está de acordo com a condição de unicidade, sendo mais compatível com a condição de maximalidade. No entanto, têm-se argumentado com base em evidências empíricas de diversas línguas que o traço inerente de definitude do artigo definido pressupõe a existência de uma entidade que seja única e familiar (pelo menos familiaridade fraca) (Roberts, 2003).

Uma possível maneira de acomodar o licenciamento de leituras de classe dentro da condição de unicidade é entender essa leitura como uma extensão pragmática do significado semântico das expressões nominais definidas. Ou seja, o significado semântico de uma expressão nominal definida sempre pressupõe uma entidade única e familiar. Essa pressuposição pode, no entendo, ser suspensa quando há pistas gramaticais (e.g. marcação de número plural na expressão nominal, predicado verbal com aspecto gramatical genérico ou habitual) ou contextuais (e.g. a entidade citada no discurso refere-se a uma classe). Ou seja, o que estamos propondo é que o artigo definido pressupõe inerentemente unicidade, mas o falante pode suspender essa pressuposição quando o contexto (gramatical ou de uso) indica que não se trata de uma entendida única ${ }^{9}$. Veja que em (7), a leitura de classe das expressões nominais "o gato" e "o cachorro" é licenciada porque o aspecto do predicado verbal é genérico. Isso leva o falante a suspender a pressuposição de unicidade na intepretação de (7).

De qualquer modo, como discutiremos no capítulo 4, é exatamente a sensibilidade às leituras de indivíduo e classe que queremos investigar. Primeiramente, queremos saber como falantes do PB ancoram essas leituras no contexto imediato de fala. Por exemplo, qual dessas leituras é mais adequada para os termos "o gato" e o "o cachorro" em (7) diante dos contextos em (9) e (10)?

\footnotetext{
${ }^{9}$ Esse tipo de negociação pragmática deve ser pensada dentro dos princípios e máximas de Grice (1957). O caso em questão, a suspensão da pressuposição de unicidade é uma maneira de atender ao princípio da coorperação.
} 
(9) Contexto 1

[A minha tia têm um gato que veio com ela da Europa e um cachorro que ela comprou no interior de Minas.]

(10) Contexto 2

[A minha tia estuda biologia animal com especialização em dieta alimentar para gato e cachorro.]

Em um segundo passo da nossa pesquisa, nos perguntamos se há alguma correlação entre traços de personalidade esquizotípica e as preferências pelas leituras em discussão, quando há uma ancoragem do referente em contextos de fala, como (9) e (10). Como já discutido anteriormente (e como discutiremos em mais detalhe na seção 3.5), há vários relatos na literatura sugerindo que o construto da esquizotipia caracteriza-se também por dificuldades em lidar com referência linguística e integração de pistas contextuais para fins interpretativos.

É importante ainda enfatizar que a construção da referencialidade linguística é parte do desenvolvimento linguístico, sendo observado durante a aquisição. Crianças falantes de inglês e francês apresentam, até por volta dos quatro anos, dificuldade em estabelecer o referente de expressões nominais definidas (Maratsos, 1976; Karmiloff-Smith, 1979; Thomas, 1989). Aos três anos, há pouca sistematicidade no uso de artigo, havendo uma tendência no uso de artigo definido no lugar do artigo indefinido ("the" no lugar de "a"), como por exemplo, quando uma entidade é introduzida no discurso pela primeira vez, violando assim a condição de familiaridade.

Estudo experimental recente sobre a intepretação de expressões nominais definidas no PB (Longchamps, 2014) indica diferenças entre crianças e adultos no que tange à interpretação de nominais definidos. $\mathrm{O}$ experimento foi conduzido da seguinte maneira: os participantes liam (ouviam, no caso das crianças) uma pequena história. Logo em seguida respondiam a uma pergunta. No experimento com as crianças acrescentou-se ainda uma imagem/cena para melhor acomodar contextualmente a história ouvida. A figura em 5, ilustra um dos estímulos usados por Longchamps ${ }^{10}$ :

\footnotetext{
${ }^{10}$ Como veremos no capítulo 4 , o experimento que conduzimos guarda semelhanças com o de Longchamps.
} 
Figura 5.

Exemplo de estímulo utilizado em Longchamps (2014: 159)

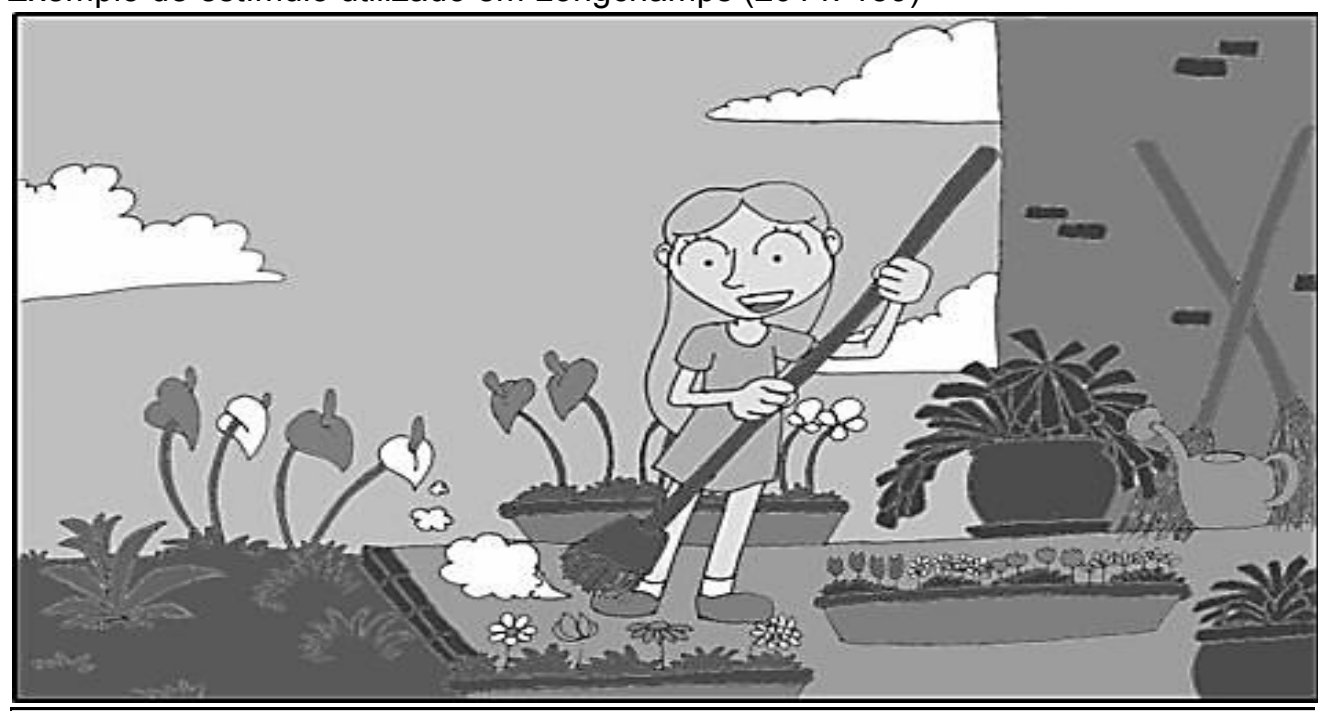

Sheila gosta de regar as plantas e de limpar 0 jardim. No domingo, ela varreu 0 jardim, guardou a/uma vassoura e foi brincar com sua amiga. Sheila guardou a vassoura que ela usou para varrer 0 jardim?

Os resultados indicam que para adultos (44 universitários com média de idade de 29 anos) o traço de definitude da expressão nominal é ostensivo e que para esses falantes a presença de modificadores contendo a expressão alvo (como sintagmas preposicionados - figura 6) aumenta a percepção do traço em questão. Isto é, familiaridade forte (Heim, 1982) aumenta a percepção do falante.

Figura 6.

Exemplo de estímulo utilizado em Longchamps (2014: 160)

Sheila gosta de regar as plantas e de limpar 0 jardim. No domingo, ela varreu 0 jardim com uma vassoura nova, guardou a/uma vassoura e foi brincar com sua amiga. Sheila guardou a vassoura que ela usou para varrer o jardim?

Já as crianças (30 alunos da rede municipal de ensino do Rio de Janeiro com faixa etária entre 8;3 e 11;6 anos), quando comparadas a adultos, apresentaram no geral dificuldade em lidar com o traço de definitude ${ }^{11}$.

Para verificar possíveis correlações entre essa dificuldade linguística e DAp - problemas de aprendizagem -, Longchamps dividiu seus participantes mirins em dois grupos: 15 crianças sem dificuldade de aprendizagem - grupo controle -

\footnotetext{
${ }^{11}$ No experimento com crianças foram utilizados apenas expressões nominais com modificador adnominal (figura 5).
} 
e 15 crianças com DAp. Os resultados sugerem diferenças significativas entre os grupos, com crianças com DAp apresentando desempenho significativamente inferior. No total, o conjunto de experimentos de Longchamps indica que crianças com DAp apresentam questões na interface gramática-pragmática com dificuldade na integração das pistas contextuais para a computação da referência de expressões nominais definidas.

Assim, concluímos essa seção chamando atenção para a necessidade de se verificar experimentalmente a sensibilidade de falantes com desordens mentais com comprometimento linguístico (brandos ou não) aos traços interpretativos de expressões nominais e às pistas contextuais que auxiliam na construção da referência deste tipo de expressão.

\section{4}

\section{Recuperando a discussão sobre referencialidade em esquizotipia/esquizofrênia}

Como já discutimos no capítulo 2, a esquizofrenia leva a problemas na composição da referência de expressões nominais. Em entrevista, um paciente insere em seu discurso a sentença "my spouse left" para algum tempo depois mencionar ter três esposas e depois indicar não ter esposa (exemplo retirado de Hinzen \& Rosselló, 2015). Portanto, parece não haver em esquizofrênicos sistematicidade no uso e interpretação de expressões nominais. Observa-se, em exemplos como esse, insensibilidade à pressuposição de existência e à condição de unicidade/maximalidade subjacente a expressões definidas. O paciente em questão parece não se dar conta de que a expressão "my spouse" é definida e como tal impõe certas restrições interpretativas, pressupondo, por exemplo, a existência de um indivíduo que satisfaça a função descrita pelo nome "spouse".

O quadro da esquizofrenia leva também à desestruturação no uso de pronomes. Os pronomes são itens lexicais referencias, assim como as expressões nominais encabeçadas por artigo definido, e como tal observam restrições interpretativas como a condição de familiaridade. No entanto, em (11 - exemplo de fala de paciente esquizofrênico), não é claro quais são os referentes dos pronomes "he" e "him", pois foram introduzidos no discurso sem maior preocupação com familiaridade e ancoramento contextual, ficando indefinida a denotação da entidade à qual os pronomes se referem. 
(11) But uh . . . my father was not a machine, my father wasn't a machine but ... he got him from a ... a little baby inside a capsule (McKenna et al., 2005: 115)

Analisando os dados de pacientes esquizofrênicos vis-à-vis os resultados obtidos de Longchamps (2014), concluímos que esquizofrênicos, assim como crianças com problemas na interface gramática-pragmática, têm problemas com a composição da referência de expressões nominais definidas, apresentando certa insensibilidade ao contexto discursivo no qual a referência se ancora.

Como já mencionado no capítulo 1, Rochester \& Martin (1979) realizaram uma análise linguística da coesão semântica do discurso de esquizofrênicos com FTD e de esquizofrênicos sem FTD. As questões linguísticas observadas foram: referência, substituição, elipses, conjunção e coesão lexical. Sendo coesão semântica entendida como aquilo que torna o texto uma unidade, ocorrendo quando a interpretação de um dado elemento do discurso depende de outro elemento, numa relação na qual um presume o outro. O exemplo em (12) ilustra coesão semântica. Para que as sentenças em (12) sejam tomadas como um único texto, o referente da expressão indefinida "a donkey" precisa ser recuperado pelo pronome "it". Essa é, portanto, uma relação de coesão que estabelece a unidade de um texto.

(12) There was a donkey about to cross the river.

It was loaded with bags of salt.

(Rochester \& Martin, 1979: 74)

Os experimentos realizados por Rochester \& Martin foram conduzidos com grupos de esquizofrênicos (10 com FTD e 10 sem, todos relativamente jovens, com nível médio de escolaridade e sem diferenças marcantes em testes de QI). O grupo controle contou com 10 participantes e, em comparação aos participantes com esquizofrenia, os participantes do grupo controle eram mais velhos, com níveis de escolaridade mais altos e com melhor performance em testes de QI. Os contextos experimentais envolveram entrevistas livres sem estruturação e com duração de 30 minutos a 1 hora, uma breve narrativa na qual os participantes 
recontavam uma história ouvida, e descrição de histórias em quadrinhos. A análise geral foi feita com amostras retiradas de cada grupo, 300 orações por grupo de forma aleatória, com uma média 2.6 itens de coesão por oração. Os resultados indicam redução de itens de coesão na fala de esquizofrênicos, mas essa redução não se correlacionou com FTD. Em uma segunda análise com foco em referência, no entanto, os autores encontraram diferenças significativas entre o grupo de pacientes com FTD e os outros grupos. Nessa análise foram considerados pronomes pessoais (e.g. "he", "she", "they"), pronomes demonstrativos (e.g. "this", "that") e termos comparativos (e.g. "smaller than", "bigger than"). O exemplo abaixo (13b), no qual um paciente com FTD reconta a história em (13a), evidencia dificuldade severa na construção da referencia de pronomes: (Rochester \& Martin, 1979: 64, 106)

(13) a. A donkey, loaded with salt had to wade a stream. He fell down and for a few minutes lay comfortably in the cool water. When he got up, he felt relieved of a great part of his burden, because the salt had dissolved in the water. The donkey took note of this advantage and applied it the following day when, this time loaded with sponges, he again went through the same stream. This time he fell purposely, but was grossly deceived. The sponges soaked up the water and were considerably heavier than before. The burden was so great that he fell and could not go on (or drowned in some versions).

b. A donkey was carrying salt/ and he went through a river/ and he decided to go for a swim/and his salt started dissolving off of him into the water/ and it did/it left him hanging there/ so he crawled out on the other side and became a mastodon/ it gets unfrozen/ it's up in the Arctic right now/it's a block of ice/ and a block of ice gets planted in/ it's forced into a square right?/ ever studied that sort of a formation, block of ice in the ground?/ well, it fights the perma frost/ it pushes it away/ and lets things go up around it/ you can see they're like, they're almost like a pattern with a flower/they start from the middle/ and it's like a submerged ice cube/that got frozen into the soil afterwards / . . . 
Embora os resultados obtidos na análise sobre referência não tenham sido replicados (cf. Harvey, 1983; Chaika \& Lambe, 1989), pesquisas posteriores corroboram os achados sobre referencialidade. Harvey (1983), por exemplo, relata que pacientes com FTD usam significativamente mais referências implícitas, genéricas e ambíguas do que pacientes sem FTD. O mesmo foi constatado por Chaika \& Lambe (1989). Dentre os 22 pacientes com FTD estudados por Chaika \& Lamb, 5 apresentaram referência imprópria para pronomes. Docherty et al. (1996) e Docherty \& Gottesman (2000) também relatam problemas com referência na esquizofrenia, embora não tracem uma correlação consistente entre FTD e problemas de referência linguística.

Problemas na computação de referentes de expressões nominais encabeçadas por artigos definidos são apresentados também por crianças em fase de aquisição da linguagem, como discutido na seção 3.4. Observa-se ainda a dificuldade que crianças têm de definir o referente de pronomes pessoais de terceira pessoa, como "ele/ela", "he/she/him/her", até por volta dos cinco anos de idade (Chien \& Wexler, 1990; Thornton \& Wexler, 1999; Grolla, 2010; Costa \& Ambulate, 2010, entre outros). Em sentenças como (14), por exemplo, é comum as crianças tomarem "John" como antecedente do pronome "him", embora na gramática do adulto, o único antecedente intrasentencial possível seja "Peter".

(14) Peter said that John saw him.

Thornton \& Wexler (1999) argumentam que crianças apresentam problemas com pronomes pessoais por estarem em fase incompleta de aquisição da pragmática. Até cinco anos, as crianças atribuem livremente aos pronomes referências que só seriam possíveis em contextos especiais de fala.

Se Thornton \& Wexler (1999) e Longchamps (2014) estiverem na trilha correta, então crianças apresentam problemas na construção da referencialidade de expressões nominais definidas por razões de pragmática (não observação a informações de contextos discursivo). A mesma questão pode estar por trás dos problemas observados no constructo da esquizotipia (em especial na esquizofrenia) e somente pesquisas com foco na interface gramática-pragmática podem avaliar a possibilidade. Essas pesquisas são necessárias para avaliarmos a 
necessidade de se promover teorias como a de Hinzen, onde não há interfaces entre linguagem e pensamento, por se tratar da mesma função cognitiva.

Hinzen \& Rosselló (2015) e Hinzen \& Sheehan (2013) apresentam problemas com a construção da referencialidade na esquizofrenia como evidência de que os processos combinatoriais da gramática se desestruturam frente à esquizofrenia. No entanto, como enfatiza Boeckx (2015), a referencialidade possibilitada pela linguagem não pode ser reduzida apenas à gramaticalização de conceitos via processos combinatórias da gramática, pois os signos linguísticos por si só não fazem referência, na medida em que são os indivíduos que fazem uso de tais construções para a realização de atos de referência. Observa-se que a proposta de Hinzen não deixa claro quais fatores linguísticos são necessários na construção da referência. $\mathrm{O}$ fato de crianças em idade de aquisição apresentarem problemas de ordem pragmática na composição da referência de pronomes e expressões nominais evidência o papel de fatores de ordem pragmática na construção da referencialidade. É preciso ainda considerar que os mesmos fatores podem estar por trás das falhas de referencialidade observadas no construto da esquizotipia. Se assim for, parece não haver evidência forte de que gramática e pensamento são a mesma função como defende Hinzen.

No próximo capítulo, apresentamos o experimento por nós conduzido no sentido de verificar se informações/pistas disponíveis no contexto de fala são consideradas na construção da referência de expressões nominais definidas por falantes do PB no geral e, em especial, verificaremos se a alta expressão de traços de personalidade esquizotípica pode influenciar no processo de construção da referencialidade. Dado que a integração de pistas de ordem discursiva são do domínio da pragmática, entendemos a nossa pesquisa como um primeiro passo na verificação de dificuldades no componente da pragmática no construto da esquizotipia.

\section{5}

\section{Conclusão parcial}

Neste capítulo, apresentamos a visão biológica da linguagem, dando ênfase a duas hipóteses sobre a arquitetura da cognição, especialmente da relação entre linguagem e pensamento: a visão cartesiana de Chomksy e a visão não-catesiana de Hinzen. 
Voltando-se para a referencialidade de expressões nominais, discutimos o traço de definitude e as restrições interpretativas desse traço. Apontamos também que no português brasileiro expressões nominais definidas podem receber leitura de indivíduo ou de classe, e observamos que crianças apresentam dificuldades com essas leituras. Essa dificuldade parece indicar questões de pragmática: falantes mirins não são eficazes no resgate de informações contextuais importantes para a construção da referência.

Assim, fechamos o capítulo nos perguntando se problemas de referência conceitual observados no construto da esquizotipia também não podem refletir questões de ordem pragmática, ou seja, alterações na integração de informações disponíveis no contexto de fala. No próximo capítulo apresentamos o experimento por nós conduzido com o objetivo de prover uma resposta preliminar a essa pergunta. 


\section{Investigando o papel do contexto na construção da referência}

Partindo de estudos já realizados sobre expressões nominais definidas no $\mathrm{PB}$ e sobre distúrbios de linguagem na esquizofrenia (e desordens associadas), elaboramos um experimento para verificar as seguintes questões:

(a) Quão sensíveis os falantes são ao contexto verbal na construção da referencialidade de expressões nominais?

(b) A esquizotipia pode levar a variação na percepção do contexto verbal, causando diferenças na construção da referência?

E iniciamos a investigação com as seguintes hipóteses:

(a) Falantes nativos de PB no geral levam em consideração informações/pistas vindas do contexto de fala para a construção da referência;

(b) A presença de traços de esquizotipia leva a alterações de sensibilidade a informações fornecidas pelo contexto. No caso em questão, a alterações na percepção das pistas dadas para a construção da referência.

Portanto, de acordo com as nossas previsões, no experimento realizado, falantes nativos do PB devem no geral escolher os referentes das expressões nominais definidas com base em informações/pistas disponíveis no contexto dado. Concentrações mais altas de traços de esquizotipia devem, no entanto, apresentar correlação com os resultados linguísticos, evidenciando diferenças na integração das pistas oferecidas pelo contexto.

\subsection{Design experimental}

Para testar a hipótese (a), conduzimos um experimento linguístico, que consistiu em uma tarefa de julgamento de aceitabilidade off-line com uso de escala Likert de 4 pontos (1-4) para avaliação de referentes de expressões 
nominais definidas dentro de contextos imediatos de fala. Manipulamos os seguintes fatores: tipo de antecedente disponível no contexto verbal (expressão indefinida específica e expressão nominal genérica realizada por nome nu (bare noun)), presença ou ausência de reforço contextual, tipo de leitura da expressão nominal definida (leitura classe e leitura de indivíduo). Obtivemos, portanto, um design $2 \times 2 \times 2$.

Afim de verificar a hipótese em (b), em um segundo momento correlacionamos, ainda que de maneira preliminar, os resultados do experimento linguístico com resultados obtidos em duas escaladas psicométricas usadas para medir traços de esquizotipia entre os participantes (SPQ e FTD-S).

\subsection{Método}

\subsubsection{Participantes}

Os participantes foram recrutados informalmente no campus da PUC-Rio e entre conhecidos dos pesquisadores e não receberam nenhum tipo de remuneração pela participação. Todos eles assinaram o termo de consentimento livre e esclarecido (TCLE) para participarem.

Cinquenta e quatro universitários participaram do estudo. Todos eles residentes do estado do Rio de Janeiro. No entanto, a amostra final consistiu de um subconjunto de 46 indivíduos, com média de idade de 25.5 anos (cf. tabela 1). Destes, 20 são do sexo masculino e 26 do sexo feminino, e 26 eram recém ingressos na universidade, enquanto 20 já haviam completado o curso superior ${ }^{1}$. Além disso, 21 deles declararam histórico de distúrbios mentais na família. Quanto a destreza manual, 38 são destros, 6 canhotos e 2 ambidestros. 43 participantes dominavam uma segunda língua, mas nenhum declarou ser bilíngue $^{2}$.

O critério de exclusão utilizado para seleção da amostra final foi: apresentar alguma desordem de linguagem (e.g. DEL - Déficit Especifico de Linguagem e

\footnotetext{
${ }^{1}$ Dado o nível universitário dos participantes, a amostra possivelmente está acima da média em termos de habilidade acadêmica, bem como em fatores sócio econômicos.

${ }^{2}$ Consideramos como bilíngues apenas indivíduos que foram expostos (com exposição robusta e equiparável) a mais de uma língua durante o período sensível de aquisição da linguagem (dos 4 meses de gestação até a entrada da puberdade - Lennneberg, 1967).
} 
Dislexia) $)^{3}$ e atribuir pelo menos uma vez, nota acima de zero a opções controle de intepretação na tarefa linguística ${ }^{4}$.

Tabela 1.

Variáveis de background da amostra final ${ }^{5}$.

\begin{tabular}{|lcccc|}
\hline \multicolumn{5}{|c|}{ Variáveis de background } \\
\hline Variáves & Média & Desvio Padrão & Mínimo & Máximo \\
\hline 1. Idade & 25,5 & 4,4 & 19 & 35 \\
2. Sexo & 1,6 & 0,5 & 1 & 2 \\
3. Escolaridade & 3,4 & 0,5 & 3 & 4 \\
4. Disturbios mentais na família & 0,5 & 0,5 & 0 & 1 \\
5. Falar idiomas estrangeiros & 0,9 & 0,3 & 0 & 1 \\
6. Lateralidade das mãos & 1,2 & 0,5 & 1 & 3 \\
\hline
\end{tabular}

Como veremos mais tarde, nenhuma dessas variáveis mostrou-se significativa para nossa análise, com exceção da variável falar idiomas estrangeiros.

\subsubsection{Materiais}

- 1 teste de linguagem (tarefa de julgamento de aceitabilidade off-line $)^{6}$

- 2 escalas psicométricas de auto-avalição (SPQ - Schizotypical Personality Questionaire, FTD-S - Formal Thought Disorder-Self) ${ }^{7}$

- 1 Questionário sobre o background sociolinguístico e psicológico dos participantes $^{8}$

- Termo de consentimento livre e esclarecido ${ }^{9}$

- 1 notebook e 2 PCs

Antes de passarmos para a apresentação do experimento linguístico, faremos aqui uma breve apresentação das escalas psicométricas de auto-avaliação usadas na pesquisa.

\footnotetext{
${ }^{3}$ Estudos experimentais com DEL (Corrêa, 2012) e dislexia (Mendes et al., 2010) indicam que essas desordens levam a dificuldades no processamento da estrutura sintática. Por essa razão, decidimos excluir da amostra participantes com desordens dessa natureza.

${ }^{4}$ Como discutiremos mais parte, as opções controle de intepretação foram inseridas para que pudéssemos identificar (e eliminar) possíveis outliers.

${ }^{5}$ As informações foram coletadas com uso de escalas ordinais ou nominais.

${ }^{6}$ Material disponível no anexo 1 da dissertação.

${ }^{7}$ Material disponível no anexo 2 da dissertação.

${ }^{8}$ Material disponível no anexo 3 da dissertação.

${ }^{9}$ Material disponível no anexo 4 da dissertação.
} 


\section{SPQ - Schizotypical Personality Questionaire}

O Questionário de Personalidade Esquizotípica (Schizotypical Personality Questionaire - SPQ) ${ }^{10}$ foi elaborado por Raine (1991) tendo como base as 9 características indicativas de Transtorno de Personalidade Esquizotípica informadas no DSM-III (APA, 1980), e ainda válidos no DSM-V (APA, 2014). Esse questionário é composto por 74 asserções respondidas com escala binária ("sim" ou "não"), e seu objetivo principal é detectar traços de personalidade esquizotípica na população normal. Contudo, também pode ser utilizado como medida para identificar diferenças individuais na personalidade esquizotípica (Vollema, et al. 2000).

A SPQ foi desenvolvida por Raine (1991) a partir de estudo experimental no qual uma amostra inicial de 302 indivíduos normais foi divida em dois grupos (1a e 1b) com 151 participantes em cada. Esses dois grupos foram usados na etapa da construção da SPQ: o grupo $1 \mathrm{~b}$ fazia a replicação dos resultados do grupo 1a. Depois, uma segunda amostra com 195 indivíduos normais foi usada para testar a replicabilidade dos resultados gerados pela primeira amostra, bem como na geração de novos itens que pudessem aumentar a confiabilidade da escala. O resultado do experimento conclui que a SPQ apresenta validade e confiabilidade robustas. Neste experimento, usou-se um modelo da escala em 9 dimensões com os seguintes fatores: ideias de referência, pensamento mágico, experiências perceptuais incomuns, ideação paranoide, ansiedade social, falta de amigos intimos, afeto constrito, fala bizarra e comportamento bizarro. Em um experimento analítico posterior (Raine et al. 1994), verificou-se que na esquizotipia, o SPQ também apresenta validade e confiabilidade como uma escala em 3 dimensões. Essas 3 dimensões reagrupam os 9 fatores do experimento anterior em 3 fatores: cognitivo-perceptual, fator interpessoal e fala desorganizada. Outros experimentos (Gruzelier, 1996; Vollema et al., 2000) também validaram o modelo de 3 dimensões. A Tabela 2 mostra os dois modelos ${ }^{11}$.

\footnotetext{
${ }^{10}$ Este questionário já tem versão em português cuja tradução foi realizada por Hélio Tonelli e, depois de revisada, retrotraduzida para o inglês por um tradutor cego para o original. Tonelli reporta a validade e confiabilidade da SPQ e aponta ser esta a única escala já traduzida para o PB.

${ }^{11}$ Todos os 74 itens estão disponíveis no anexo 2 desta dissertação.
} 
Tabela 2.

Organização dos 74 itens da SPQ nos modelos de 9 e 3 dimensões ${ }^{12}$.

\begin{tabular}{|c|c|c|}
\hline SPQ 9 dimensões & SPQ 3 dimensões & itens \\
\hline 1:ideias de referência & \multirow{4}{*}{ 1: cognitiva perceptual } & $1,10,19,28,37,45,53,60$ e 63 \\
\hline 2: pensamento mágico & & $3,12,21,30,39,47$ e 55 \\
\hline 3: experiências perceptuais incomuns & & $4,13,22,31,40,48,56,61$ e 64 \\
\hline 4:ideação paranoide & & $9,18,27,36,44,52,59$ е 65 \\
\hline 5: ansiedade social & \multirow{3}{*}{ 2: interpessoal } & $11,20,29,38,46,54$ e 71 \\
\hline 6: falta de amigos íntimos & & $6,15,24,33,41,49,57,62$ e 66 \\
\hline 7: afeto constrito & & $8,17,26,35,43,51,68$ e 73 \\
\hline 8: fala bizarra & \multirow{2}{*}{ 3: desorganização } & $7,16,25,34,42,50,58,69$ e 72 \\
\hline 9: comportamento bizarro & & $5,14,23,32,67,70$ e 74 \\
\hline
\end{tabular}

Raine (1991) reporta que 55\% dos participantes com pontuação alta tiveram diagnóstico de TEP (segundo critério do DSM III), e os $45 \%$ restante tinham entre 3 e 5 traços esquizotípicos no nível de threshold ou subthreshold. Para chegar a esses percentuais, Raine fez um cutoff de $10 \%$ das pontuações obtidas, considerando os $10 \%$ das pontuações mais altas e os $10 \%$ das pontuações mais baixas (ou seja, as pontas das pontuações obtidas). O cutoff de 10\% gerou, portanto, grupos que foram investigados para esquizotipia.

Em nossa análise, fizemos uso do modelo de 9 dimensões proposto por Raine $(1991)^{13}$. No entanto, dada a pequena amostra com a qual trabalhamos, não foi realizado cutoff e, portanto, não trabalhamos com grupos ${ }^{14}$. Fizemos apenas uma correlação entre os resultados obtidos no SPQ e os resultados obtidos no experimento linguístico.

\footnotetext{
${ }^{12}$ Os itens da dimensão "ideação paranoide" do modelo de 9 dimensões estão incluídos nas dimensões 1 e 2 do modelo com 3 dimensões.

${ }^{13}$ Essa escolha deve-se ao fato de esse modelo ter se mostrado estatisticamente mais revelador de correlações com os resultados linguísticos.

${ }^{14}$ Com o cutoff de $10 \%$, nossa amostra para esquizotipia contaria apenas com $+/-5$ indivíduos.
} 


\section{FTD-S - Formal Thought Disorder-Self}

O questionário Formal Thought Disorder-Self (Report) (FTD-S), elaborado por Barrera et al. (2015), é uma variação de um instrumento ${ }^{15}$ usado originalmente para medir FTD em pacientes esquizofrênicos com uso de escala binária (Sim/Não). Contudo, os autores mudaram para uma escala Likert de 4 pontos (1 a 4) por ser esta uma escala mais sensível às especificidades características de uma população não clínica. A FTD-S foi elaborada para medir FTD e outros aspectos pragmáticos, paralinguísticos, não verbais e cognitivos da fala, fornecendo um retrato detalhado dos distúrbios de comunicação.

A escala foi validada com uma amostra de indivíduos normais $(n=300)$ que responderam anonimamente a versão online do questionário. O estudo apresentou confiabilidade interna robusta. Um segundo estudo examinou a relação entre a escala de FTD-S (em uma amostra de 159 indivíduos normais) e uma escala (FTD-Other ${ }^{16}$ ), respondida por um amigo ou parente próximo do participante (amostra de 114 indivíduos normais). A FTD-S também apresentou validade e confiabilidade robustas na organização de seus 29 itens em 3 fatores: fala bizarra, habilidades para conversas e memória de trabalho (ver Tabela $3^{17}$ ).

Barrera et al. (2015) não informam percentuais de cutoff, apenas a média total 23,0 $(\mathrm{DP}=9,9)$, e por dimensão (dimensão 1: média $=10,5(\mathrm{DP}=4,9)$; dimensão 2: média $=6,2(\mathrm{DP}=3,5)$; dimensão 3: média $=6,3(\mathrm{DP}=3,8))$.

\section{Tabela 3.}

Padrão de organização dos itens da FTD-S: 3 dimensões.

\begin{tabular}{|l|l|}
\hline \multicolumn{2}{|c|}{ FTD-S 3 dimensões } \\
\hline Dimensão 1: fala bizarra & $\begin{array}{l}7,12,13,14,15,16,17,18,19,22,23,24, \\
25,27 \text { e } 28\end{array}$ \\
Dimensão 2: habilidade para conversas & $4,8,9,10,11,20$ e 26 \\
Dimensão 3: memória de trabalho & $1,2,3,5,6,21$ e 29 \\
\hline
\end{tabular}

\footnotetext{
${ }^{15}$ Esse instrumento foi elaborado por Barrera et al. (2008) para medir sintomas relacionados ao pensamento/linguagem em indivíduos com psicose. Ele foi validado em uma amostra de 90 pacientes esquizofrênicos.

${ }^{16}$ Essa escala tem 33 itens adaptados para avaliar outras pessoas e é normalmente usada por cuidadores para avaliar pacientes com desordens mentais.

${ }^{17}$ Os 29 itens estão disponíveis no anexo 2 desta dissertação.
} 
Para a nossa pesquisa, fizemos primeiramente a tradução e a retrotradução da FTD-S para o português ${ }^{18}$ e usamos a escala traduzida nos moldes do estudo original (i.e. como proposto por Barrera et al., 2015). Todos os itens (29 no total) foram respondidos com uso de escala Likert de 4 pontos (1 a 4$)$.

\subsubsection{Estímulos linguísticos}

O teste linguístico consistiu de 50 itens experimentais: 20 itens-alvo (5 itens por condição) e 30 distratores. A apresentação dos itens experimentais foi precedida por 3 itens de treino, similares aos distratores que compreendiam estruturas sentenciais envolvendo posse inalienável e elipses ${ }^{19}$.

Dado o design do experimento $(2 \times 2 \times 2)$, obtivemos 8 condições experimentais, a saber:

Tabela 4.

Condições experimentais.

\begin{tabular}{|l|c|c|c|}
\hline \multicolumn{1}{|c}{ Condições } & \multicolumn{1}{c}{ tipo de antecedente } & \multicolumn{1}{c|}{ sentença reforço } & \multicolumn{1}{c|}{ tipo de leitura } \\
\hline Condição 1 & indefinido específico & com reforço & classe \\
Condição 2 & indefinido específico & com reforço & indivíduo \\
Condição 3 & indefinido específico & sem reforço & classe \\
Condição 4 & indefinido específico & sem reforço & indivíduo \\
Condição 5 & singular nu & com reforço & classe \\
Condição 6 & singular nu & com reforço & indivíduo \\
Condição 7 & singular nu & sem reforço & classe \\
Condição 8 & singular nu & sem reforço & indivíduo \\
\hline
\end{tabular}

Os itens experimentais apresentados nas figuras 7, 8, 9 e 10 ilustram as condições $^{20}$. Note-se que cada item contém 2 condições (opção de leitura ${ }^{21}$ a ser avaliada - de classe/de indivíduo). Assim, a figura 7 ilustra as condições 1 e 2, a figura 8 ilustra as condições 3 e 4, a figura 9 ilustra as condições 5 e 6 e a figura 10 ilustra as condições 7 e 8 .

\footnotetext{
${ }^{18}$ Tradução feita por mim (Monica Chaves) e retrotradução feita por Leslie Rose (Programa de Pós-graduação em Estudos da Linguagem/PUC-Rio) .

${ }^{19}$ Os 3 itens de treino diferenciaram dos distratores por conter 1 item sobre quantificação (1 item de posse inalienável, 1 item de elipses e um 1 item de quantificação). Inserimos a quantificação para os itens de treino serem diferentes uns dos outros.

${ }^{20}$ Os exemplos dados ilustram como os itens do teste de linguagem foram apresentados aos participantes na plataforma. $\mathrm{O}$ asterisco vermelho indica que estes itens eram de resposta obrigatória. Isto é, o participante não consegue passar para outro item sem avaliar o item presente, mas, esta marca aparece apenas na versão do questionário para o pesquisador.

${ }^{21}$ Há sempre uma opção de leitura iniciada por pronome indefinido nenhum(a) usada como controle. Qualquer avaliação maior do que 1 de qualquer uma dessas opções controle levou a exclusão do participantes.
} 
Figura 7.

Indefinido específico, com reforço, leituras

$\begin{aligned} & \text { A minha amiga comeu um bombom de chocolate belga. Ela teve uma reaçăo alérgica. Ela comentou que o } \\ & \text { bombom leva açúcar demais. } \\ & \text { - O que leva açúcar demais? * }\end{aligned}$ - bombom de chocolate belga que a minha amiga comeu
Nenhum bombom
Qualquer bombom

Figura 8.

Indefinido específico, sem reforço, leituras

A minha cunhada comprou um cachorro de raça grande. Ela me contou que o cachorro sabe pelo cheiro se uma
pessoa está doente.
-Quem sabe pelo cheiro se uma pessoa está doente? *
Qualquer cachorro
Nenhum cachorro
cachorro de raça grande que a minha cunhada comprou

Figura 9.

Singular nu, com reforço, leituras

O meu primo criou abelha na infância. Ele cresceu num sítio em Minas. Ele me falou que a abelha é muito pouco estudada.

- O que é muito pouco estudado? *

A abelha que o meu primo criou na infância

Qualquer abelha

Nenhuma abelha

Figura 10.

Singular nu, sem reforço, leituras

O Renato vendeu faca na juventude. Ele me contou que a faca é da Ásia.
- O que é da Ásia? *
Qualquer faca
Nenhuma faca

Observa-se, ainda, que a avaliação de dois tipos de leitura no mesmo estímulo poderia causar interferência. Contudo, experimento anterior (Rodrigues e Dal Pozzo, 2016) fez uso do mesmo tipo de design e apresentou resultados robustos. Há, portanto, evidência de que esse design não tem efeito marcadamente 
negativo ou positivo nos resultados obtidos. O mesmo pode ser dito do nosso experimento (ver seção 4.3), na medida em que os resultados obtidos além de se mostrarem robustos estão de acordo com a literatura na área.

Como os exemplos mostram, o contexto verbal dado sempre antecede o aparecimento da expressão nominal definida (expressão alvo do experimento).

$\mathrm{O}$ antecedente (expressão nominal indefinida ou nome nu) aparece sempre como objeto sintático na sentença que abre o contexto e é sempre no singular, sendo também sempre seguido de um adjunto - sintagma preposicionado. O tempo desta sentença é sempre passado do indicativo para não interferir (facilitar ou dificultar) as avaliações interpretativas a serem feitas. Dado que nomes nus recebem interpretação genérica, referindo-se a classes de indivíduos, espera-se que quando o antecedente for um nome nu, a expressão nominal definida receba preferencialmente uma leitura de classe. Em contraste, quando o antecedente for uma expressão indefinida, espera-se que a expressão nominal definida seja interpretada como referindo-se à um indivíduo.

A sentença reforço é também sempre no passado do indicativo. A manipulação desse fator foi feita com o intuito de verificar se a presença de reforço contextual tornaria as pistas contextuais mais ostensivas, aumentando a coesão semântica entre o antecedente e a expressão nominal definida.

O fator tipo de leitura aparece como opções de respostas (sendo de fato opções interpretativas) para a pergunta gatilho. A expressão nominal definida é embutida na pergunta gatilho como o operador (pronome interrogativo) da pergunta. A opção de leitura com o quantificador nenhum/nenhuma não é uma interpretação possível, dado a pressuposição de existência do artigo definido. Por isso, esta opção foi inserida no experimento como um controle.

Cabe ainda ressaltar que a expressão nominal definida aparece como tal dentro de uma oração subordinada a um verbo discendi (e.g. "dizer", "contar", "falar"), o que tem como efeito a suspensão de valor de verdade da oração subordinada. Isso significa que não há exigência de que a asserção feita sobre a expressão nominal definida seja verdadeira para que a sentença toda o seja. Isto é, o contexto contém uma declaração sobre o que foi dito por alguém e não cabe ao participante julgar o valor da asserção feita ${ }^{22}$.

\footnotetext{
${ }^{22}$ Acreditamos que os participantes que valoraram a opção controle o fizeram com base em julgamentos desta natureza.
} 
Controlamos também o gênero dos itens lexicais para que não houvesse clash entre os referentes citados no contexto. Além disso, controlamos também a plausibilidade das opções das leituras dadas.

\subsubsection{Procedimento}

O experimento contendo os estímulos linguísticos, as escalas psicométricas e o questionário de background foi realizado na plataforma Online Pesquisa (https://www.onlinepesquisa.com), mas respondido na presença do pesquisador ou do colaborador envolvidos na pesquisa ${ }^{23}$. Não houve nenhum tipo de interferência da nossa parte nas respostas dadas pelos participantes.

Todos os testes foram realizados em ambiente isento de distrações auditivas ou visuais externas ${ }^{24}$.

Antes de iniciar o experimento, os participantes foram instruídos sobre a natureza do experimento e em seguida, foram solicitados a ler atentamente e assinar o TCLE.

Os questionários e testes de linguagem foram respondidos na seguinte ordem: FTD-S, teste linguagem, SPQ, questionário de background.

Antes de iniciar cada teste, os participantes receberam na própria tela do computador instruções específicas sobre como responder o teste em questão. Os dois questionários de auto-avalição de traços psicológicos (FTD-S e SPQ) foram apresentados de forma que o participante pudesse ver todos os itens de maneira corrida, em uma única página da plataforma.

O teste de compreensão de linguagem continha, após as instruções iniciais, 3 itens de treino, de aquecimento, para que os participantes se acostumassem com o tipo de teste. Nesse teste e no questionário de background, os itens foram apresentados um a um; isto é, um por página. Especificamente no teste de linguagem, não era possível proceder (i.e. mudar de página) sem responder o item presente e também não era possível retroceder e reavaliar itens já avaliados. Isso para que a avalição de cada item refletisse a reação intuitiva do falante para o estímulo dado, sem interferência de outras variáveis. Com exceção dos itens de

\footnotetext{
${ }^{23}$ Os experimentos foram realizados na minha presença (Monica chaves) ou na presença de Isabela Soares Bastos, bolsista PIBIC/PUC-RIO, participante do projeto Pronomes, coordenado pela orientadora da pesquisa, Professora Dra. Cilene Rodrigues, e do qual a presente pesquisa faz parte.

${ }^{24}$ Foram utilizados o laboratório Mograbi/PUC-Rio, dirigido pelo Professor Dr. Daniel Mograbi, coorientador da pesquisa, e uma sala isolada de reunião do Departamento de Letras da PUC-Rio.
} 
treino, todos os itens do teste de linguagem foram aleatorizados por participante e as opções de leitura também, de modo a evitar efeito de posição na série (efeitos de primazia e recência - Murdock, 1962)

Optamos por usar uma escala de Likert de 4 pontos (1 a 4) no teste linguístico para que não houvesse mudanças de escala entre este teste e o questionário FTD-S, que o precedia imediatamente.

\subsection{Análise estatística}

\subsubsection{Teste de linguagem}

Os dados linguísticos foram analisados por meio de ANOVA com medidas repetidas intraparticipantes. Dois fatores acarretaram efeitos principais significativos: tipo de leitura $(\mathrm{p}=.001)$ (gráfico 1) e tipo de antecedente $(\mathrm{p}=.001)$ (gráfico 2). $\mathrm{O}$ fator reforço contextual não se mostrou significativo $(\mathrm{p}=.870)$.

O efeito de tipo de leitura revela que no geral os participantes atribuíram significativamente valores mais altos à leitura de indivíduo.

Gráfico 1. Julgamento de aceitabilidade em função do tipo de leitura

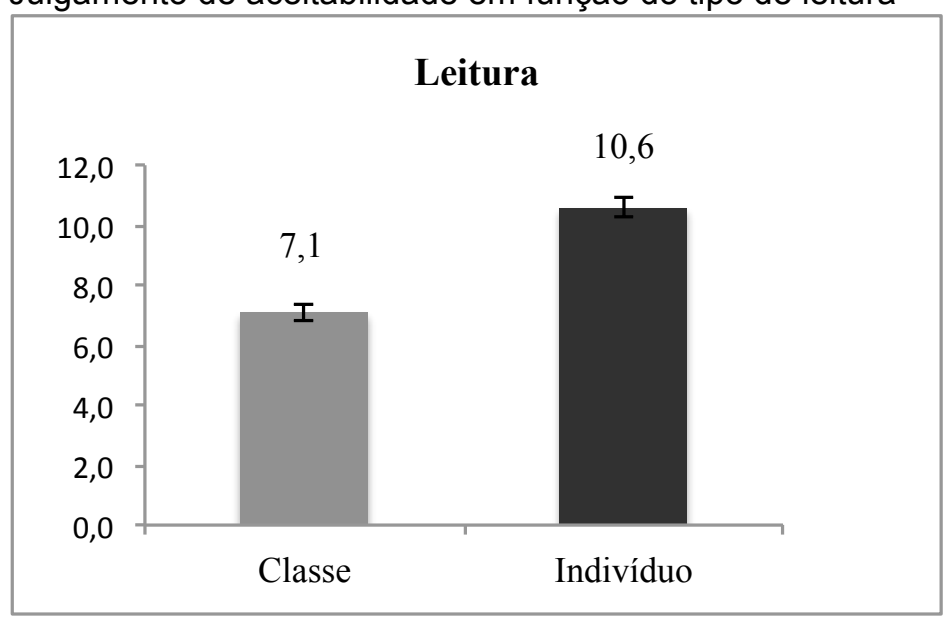

$\mathrm{O}$ efeito de tipo de antecedente mostra que os participantes elevaram os valores atribuídos à leitura de classe na condição de nome nu. Isto é, os valores atribuídos à leitura de indivíduo são sempre altos em comparação aos valores da leitura de classe, mas na condição de nome nu (em contraste com a condição de indefinido), os valores atribuídos a leitura de classe sobem, puxando a condição de nome nu para cima. $\mathrm{O}$ efeito de interação entre tipo de antecedente e tipo de 
leitura, que discutiremos a seguir, mostra preferência significativa pela leitura de classe quando o antecedente é um nome nu.

Gráfico 2.

Julgamento de aceitabilidade em função do tipo de antecedente

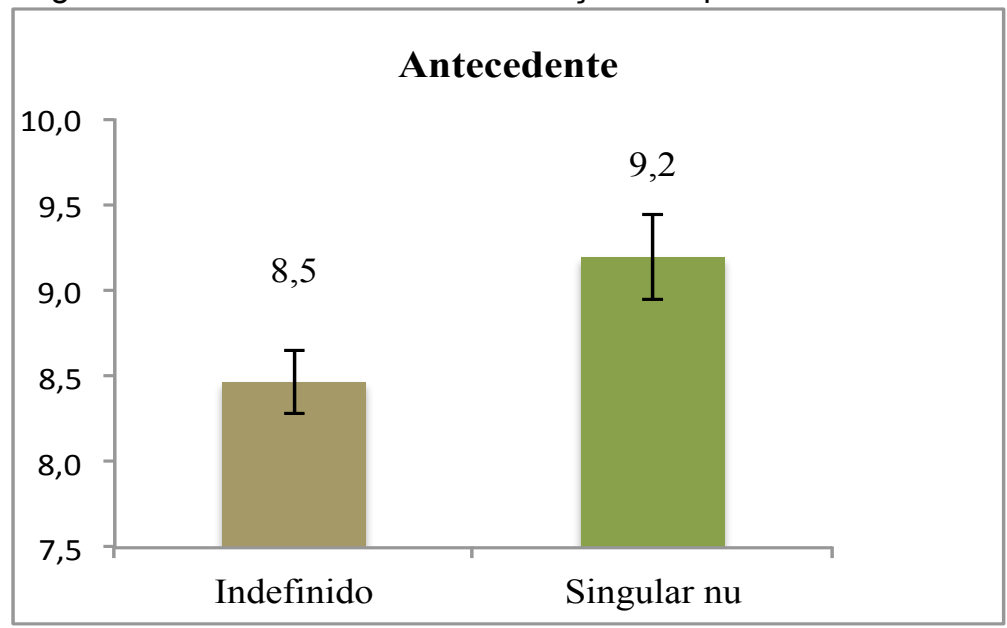

Houve efeitos significativos da interação entre tipo de antecedente e tipo de leitura ( $p=.001)$ (gráfico 3); tipo de antecedente e reforço contextual ( $p=.039$ ) (gráfico 4); reforço contextual e tipo de leitura ( $p=.023)$ (gráfico 5); tipo de antecedente, reforço contextual e tipo de leitura ( $p=.025)$ (gráfico 6).

A interação entre tipo de antecedente e tipo de leitura nos mostra que a leitura varia de acordo com antecedente dado. Se o antecedente for uma expressão indefinida, a leitura preferida é a de indivíduo. No entanto, se o antecedente for um nome nu, há uma significativa preferência pela leitura de classe.

Gráfico 3.

Julgamento de aceitabilidade em função do tipo de antecedente e tipo de leitura

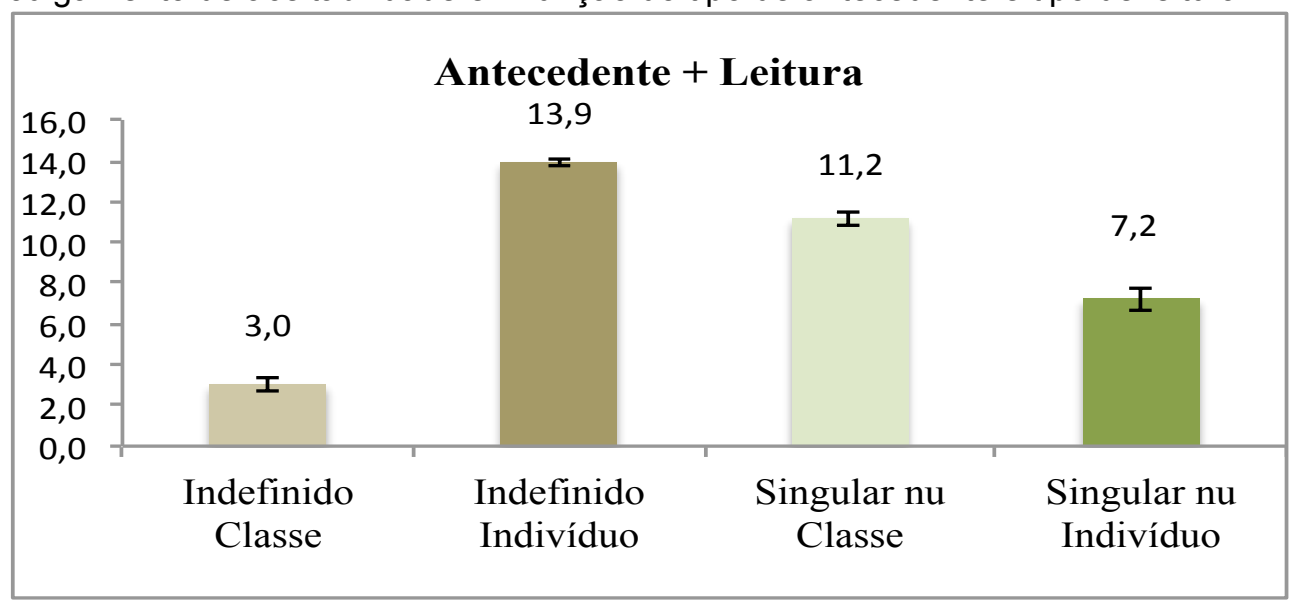


A interação entre tipo de antecedente e reforço contextual nos mostra que o os valores atribuídos às condições com nome nu aumentam quando há reforço contextual $^{25}$.

Gráfico 4.

Julgamento de aceitabilidade em função do tipo de antecedente e reforço contextual

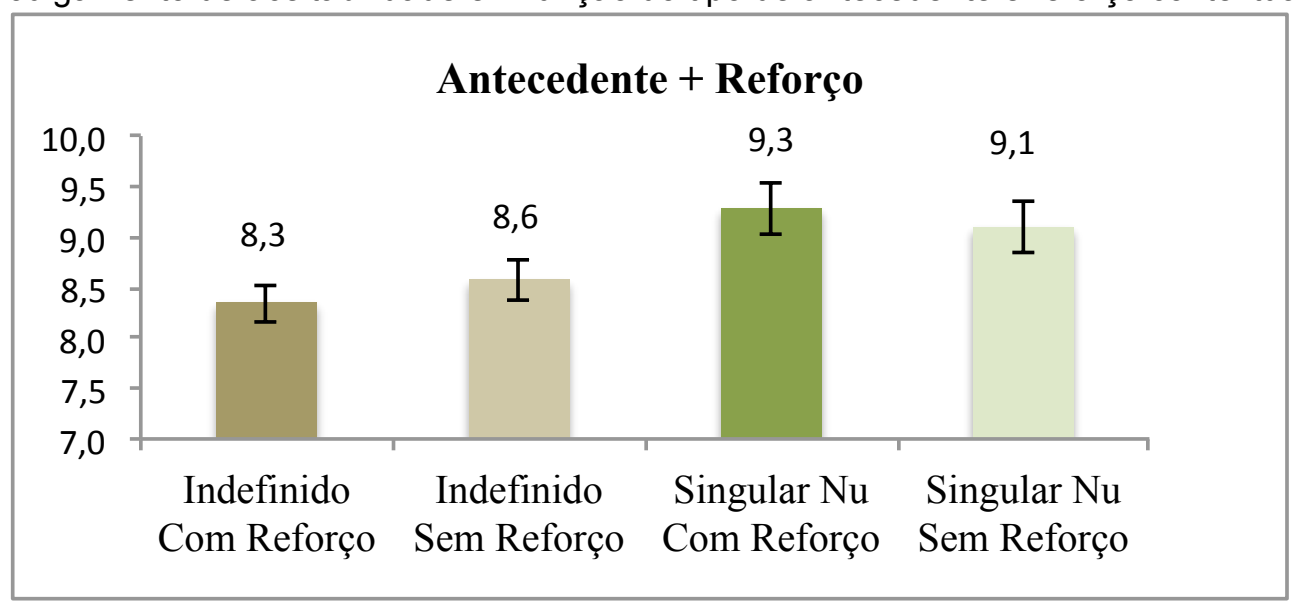

A interação entre tipo de leitura e reforço contextual demonstra que o reforço contextual aumenta a leitura de classe, especialmente na condição de nome $\mathrm{nu}^{26}$.

\section{Gráfico 5.}

Julgamento de aceitabilidade em função de reforço contextual e tipo de leitura

\begin{tabular}{|c|c|c|c|c|}
\hline & & Reforço + I & itura & \\
\hline & & 10,3 & & 10,9 \\
\hline 10,0 & 7,4 & I & & \\
\hline 8,0 & $I$ & & 0,0 & \\
\hline 6,0 & & & & \\
\hline 4,0 & & & & \\
\hline 2,0 & & & & \\
\hline & $\begin{array}{c}\text { Com reforço } \\
\text { Classe }\end{array}$ & $\begin{array}{l}\text { Com reforço } \\
\text { Indivíduo }\end{array}$ & $\begin{array}{c}\text { Sem reforço } \\
\text { Classe }\end{array}$ & $\begin{array}{l}\text { Sem reforço } \\
\text { Indivíduo }\end{array}$ \\
\hline
\end{tabular}

$25 \mathrm{O}$ que fica evidente quando consideramos as comparações por pares (pairwise comparisions):

$[$ Indef,+ Reforço, classe] $v$ s [Indef, - Reforço, classe]: $p=.488$

[Indef, + Reforço, Indiv.] vs [Indef, -Reforço, Indiv ]: $p=.530$

$[\mathrm{Nu},+$ Reforço, classe $]$ vs $[\mathrm{Nu},-$ Reforço, classe $]: p=.002$

$[\mathrm{Nu},+$ Reforço, Indiv $] v s[\mathrm{Nu},-$ Reforço, Indiv $]: p=.030$

${ }^{26}$ Ver Nota de rodapé anterior. 
Em resumo, os efeitos principais e as interações encontrados mostram que a leitura de indivíduo é significativamente a preferida, mas na condição em que o antecedente é um nome nu, a leitura de classe é melhor avaliada, especialmente quando há reforço contextual.

O gráfico 6 resume nossos resultados, tabela 5 apresenta os efeitos principais e as interações encontradas e a tabela 6 descreve os dados descritivos das oito condições.

Gráfico 6.

Julgamento de aceitabilidade em função de tipo de antecedente, reforço contextual e tipo de leitura

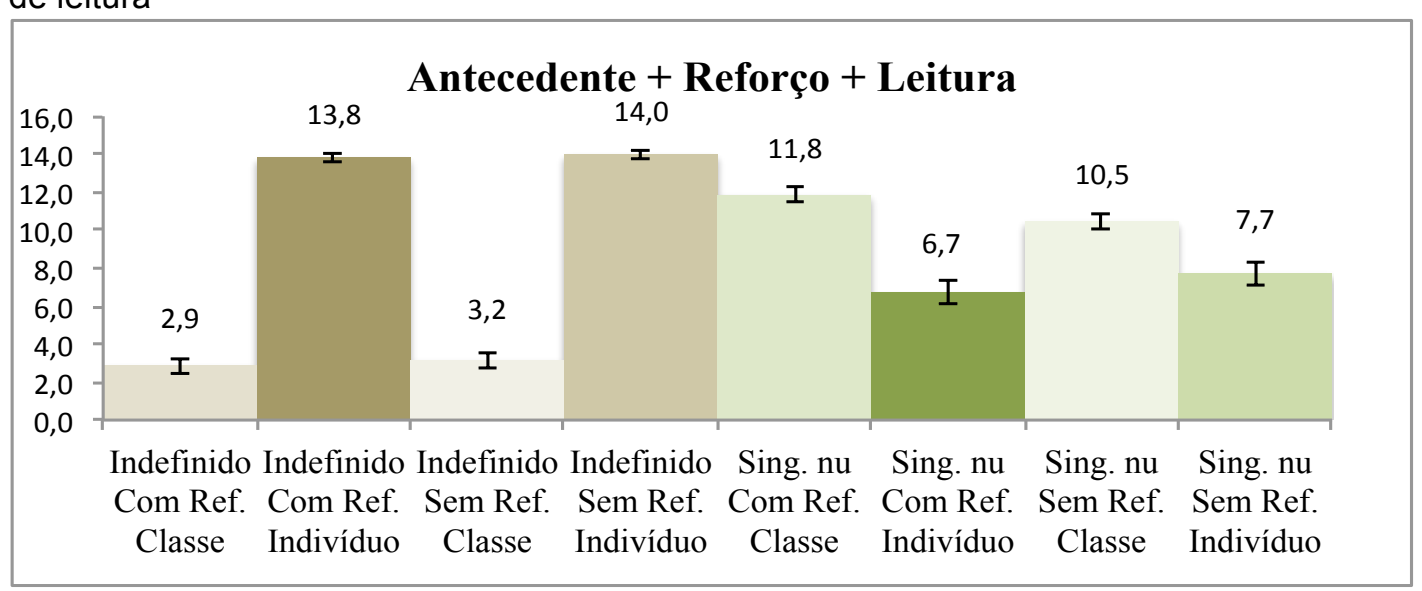

Tabela 5.

Efeitos principais do teste de linguagem

\begin{tabular}{lcc}
\hline Efeito & $\mathrm{F}(1,45)$ & Sig. $p$ \\
\hline Antecedente & 18,0 & 0,001 \\
Interveniente & 0,0 & 0,870 \\
Leitura & 48,6 & 0,001 \\
Antecedente * Interveniente & 4,5 & 0,039 \\
Antecedente * Leitura & 315,0 & 0,001 \\
Interveniente * Leitura & 5,6 & 0,023 \\
Antecedente * Interveniente * Leitura & 5,4 & 0,025 \\
\hline * significância p $<0,05$ & \\
\hline
\end{tabular}

Tabela 6

Informações descritivas das 8 condições do teste de linguagem

\begin{tabular}{lcccc}
\hline Condições & Média & DP & Mínimo & Máximo \\
\hline 1. Indef. com reforço leitura de classe & 2,9 & 2,8 & 0 & 12 \\
2. Indef. com reforço leitura de indivíduo & 13,8 & 1,5 & 9 & 15 \\
3. Indef. sem reforço leitura de classe & 3,2 & 2,8 & 0 & 10 \\
4. Indef. sem reforço leitura de indivíduo & 14,0 & 1,6 & 9 & 15 \\
5. Sing. nu com reforço leitura de classe & 11,9 & 2,6 & 5 & 15 \\
6. Sing. nu com reforço leitura de indivíduo & 6,7 & 4,0 & 0 & 15 \\
7. Sing. nu sem reforço leitura de classe & 10,5 & 3,0 & 4 & 15 \\
8. Sing. nu sem reforço leitura de indivíduo & 7,7 & 4,3 & 0 & 15 \\
\hline
\end{tabular}




\subsubsection{Questionário de variáveis de background e correlações com o teste de linguagem e com os questionários psicométricos}

Como já afirmado anteriormente, o questionário de variáveis de background foi realizado para coletar informações dos participantes que pudessem apresentar possíveis correlações com as condições do teste de linguagem e com os itens dos questionários de avalição psicométrica.

Não encontramos correlações significativas entre as condições do teste linguístico e as variáveis idade, lateralidade manual, sexo, distúrbios mentais na família e escolaridade. Contudo, encontramos correlação entre a variável falar idiomas estrangeiros e a condição 4 do teste de linguagem (antecedente indefinido, sem reforço, leitura de indivíduo) $(p=.024)$. A Tabela 7 informa o resultado da análise das correlações.

Tabela 7.

Correlações entre as variáveis background e as condições do teste de linguagem.

\begin{tabular}{lcccrrc}
\hline & 1 & 2 & 3 & 4 & 5 & 6 \\
\hline Cond 1 & $-0,08$ & $-0,25$ & 0,10 & $-0,11$ & 0,08 & 0,22 \\
& 0,620 & 0,100 & 0,492 & 0,452 & 0,586 & 0,142 \\
\hline Cond 2 & 0,05 & $-0,01$ & $-0,05$ & 0,14 & $-0,21$ & $-0,04$ \\
& 0,751 & 0,926 & 0,768 & 0,368 & 0,166 & 0,811 \\
\hline Cond 3 & $-0,05$ & $-0,06$ & $-0,03$ & 0,08 & $-0,08$ & 0,15 \\
& 0,734 & 0,682 & 0,833 & 0,621 & 0,597 & 0,335 \\
\hline Cond 4 & 0,18 & $-0,11$ & 0,28 & $-0,06$ &, $333^{*}$ & $-0,03$ \\
& 0,224 & 0,465 & 0,063 & 0,717 & 0,024 & 0,859 \\
\hline Cond 5 & 0,02 & 0,02 & $-0,03$ & 0,04 & $-0,02$ & $-0,02$ \\
& 0,921 & 0,915 & 0,827 & 0,807 & 0,918 & 0,872 \\
\hline Cond 6 & $-0,06$ & $-0,13$ & $-0,03$ & 0,08 & $-0,11$ & 0,16 \\
& 0,719 & 0,391 & 0,863 & 0,612 & 0,474 & 0,285 \\
\hline Cond 7 & $-0,11$ & $-0,04$ & 0,18 & $-0,01$ & 0,01 & $-0,15$ \\
& 0,471 & 0,779 & 0,243 & 0,955 & 0,942 & 0,310 \\
\hline Cond 8 & 0,16 & $-0,08$ & 0,08 & 0,04 & $-0,08$ & 0,25 \\
& 0,298 & 0,621 & 0,621 & 0,813 & 0,603 & 0,095 \\
\hline
\end{tabular}

* Correlação é significante no nível 0.05 (2-tailed).

** Correlação é significante no nível 0.01 (2-tailed).

Nota: As vaiáveis sociolinguísticas 1, 2, 3, 4, 5 e 6 correspondem, respectivamente a idade, sexo, escolaridade, distúrbios mentais na família, falar idiomas estrangeiros e lateralidade manual.

Portanto, a correlação encontrada e a análise dos dados brutos indicam que, em comparação a participantes que não falam uma segunda língua, participantes que declararam ter domínio de outro idioma estrangeiro atribuem notas mais altas aos itens da condição 4. 
Houve também correlações entre variáveis de background e a dimensão 2 do FTD-S. Como a Tabela 8 nos mostra, houve correlação negativa com as variáveis idade $(p=.006)$ e escolaridade $(p=.007)$, e correlação positiva com distúrbios mentais na família $(p=.044)$. Portanto, quanto mais jovem o participante maior foi sua pontuação na dimensão 2 do FTD-S. Acreditamos que a correlação com escolaridade está ligada à correlação com idade, já que pessoas mais jovens (universitários, no caso específico) têm níveis mais baixos de escolaridade. A correlação positiva com a variável distúrbios mentais na família é um resultado importante da nossa pesquisa, pois corrobora a validade da FTD-S por nós utilizada.

Tabela 8.

Correlações entre as variáveis background e a Dimensão 2 do FTD-S (n=46)

\begin{tabular}{ccccccc}
\hline & 1 & 2 & 3 & 4 & 5 & 6 \\
\hline \multirow{2}{*}{ SPQ AC } & $-0,23$ & 0,21 &,$- 292^{*}$ & 0,21 & $-0,28$ & $-0,22$ \\
& 0,126 & 0,162 & 0,049 & 0,156 & 0,057 & 0,135 \\
\hline FTD-S &,$- 401^{* *}$ & 0,14 &,$- 391^{* *}$ &, $298^{*}$ & $-0,17$ & $-0,20$ \\
Dimensão2 & 0,006 & 0,357 & 0,007 & 0,044 & 0,272 & 0,175 \\
\hline
\end{tabular}

** Correlação é significante no nível 0.01 level (2-tailed).

* Correlação é significante no nível 0.05 level (2-tailed).

As vaiáveis de background 1, 2, 3, 4, 5 e 6 correspondem, respectivamente a idade, sexo, escolaridade, distúrbios mentais na família, falar idiomas estrangeiros e lateralidade manual.

\subsubsection{Questionários psicométricos (SPQ e FTD-S) e correlações com o teste de linguagem}

SPQ - Schizotypical Personality Questionaire

Na presente pesquisa, o SPQ total dos participantes apresentou média igual a 44,7 (SD=12,8; min.= 20 e máx.=69). No modelo com 9 fatores, obtivemos as seguintes medias por fator:

- Ideia de referência ${ }^{27}: 4,2(\mathrm{DP}=2,0)$

- Pensamento mágico: 2,0 (DP=2,1)

- Experiências perceptuais incomuns: $3,1(\mathrm{DP}=2,5)$

- Ideação paranoide: $3,7(\mathrm{DP}=2,4)$

- Ansiedade social: 4,5 (DP=2,5)

- Falta de amigos íntimos: 2,8 (DP=2,3)

\footnotetext{
${ }^{27}$ Ideias de Referência são "interpretações incorretas de incidentes casuais e eventos externos como tendo um sentido particular e incomum especificamente para a pessoa" (APA, 2014: 656).
} 
- Afeto constrito: $2,6(\mathrm{DP}=1,6)$

- Fala bizarra: 3,8 (DP=2,4)

- Comportamento bizarro: 2,6 (DP=2,5)

A Tabela 9 resume a descrição estatística dos dados:

Tabela 9.

Descrição estatística dos 9 fatores do SPQ, incluindo média, desvio padrão, máximo e mínimo obtido nas 9 dimensões.

\begin{tabular}{lcccc}
\hline Fatores & média & desvio padrão & mínimo & máximo \\
\hline 1. ideias de referência & 4,2 & 2,0 & 0 & 9 \\
2. pensamento mágico & 2,0 & 2,1 & 0 & 7 \\
3. experiências perceptuais incomuns & 3,1 & 2,5 & 0 & 8 \\
4. ideação paranoide & 3,7 & 2,4 & 0 & 8 \\
5. ansiedade social & 4,5 & 2,5 & 0 & 8 \\
6. falta de amigos íntimos & 2,8 & 2,3 & 0 & 8 \\
7. afeto constrito & 2,6 & 1,6 & 0 & 6 \\
8. fala bizarra & 3,8 & 2,4 & 0 & 8 \\
9. comportamento bizarro & 2,6 & 2,5 & 0 & 7 \\
\hline
\end{tabular}

Ao correlacionarmos o resultados do SPQ em 9 dimensões e as condições do teste de linguagem, obtivemos os seguintes resultados (Tabela 10):

Tabela 10 .

Correlações entre SPQ 9 dimensões e condições do teste de linguagem $(n=46)$.

\begin{tabular}{lccccccccc}
\hline & \multicolumn{10}{c}{ Correlações } \\
\hline \multirow{3}{*}{ Cond. 1 } & SPQ IR & SPQ PM & SPQ EPI & SPQ IP & SPQ AS & SPQ FAI & SPQ AC & SPQ FB & SPQ CB \\
& $-0,03$ & 0,17 & 0,04 & $-0,16$ & $-0,22$ & $-0,24$ &,$- 349^{*}$ & $-0,04$ & $-0,06$ \\
& 0,844 & 0,269 & 0,811 & 0,282 & 0,146 & 0,103 & 0,018 & 0,805 & 0,681 \\
Cond.2 & $-0,07$ & $-0,11$ & $-0,04$ & 0,18 & 0,05 & 0,25 &, $302 *$ & 0,06 & 0,09 \\
& 0,659 & 0,484 & 0,807 & 0,223 & 0,761 & 0,093 & 0,041 & 0,715 & 0,562 \\
Cond 3 & $-0,14$ & 0,03 & 0,27 & $-0,18$ & $-0,11$ & $-0,05$ & $-0,26$ & $-0,12$ & 0,03 \\
& 0,340 & 0,823 & 0,075 & 0,227 & 0,450 & 0,728 & 0,086 & 0,434 & 0,835 \\
Cond. 4 & 0,07 & 0,01 & $-0,28$ & $-0,06$ & $-0,16$ & $-0,17$ & $-0,11$ & $-0,12$ & $-0,13$ \\
& 0,648 & 0,965 & 0,063 & 0,700 & 0,304 & 0,248 & 0,460 & 0,448 & 0,392 \\
Cond. 5 & $-0,03$ & 0,11 & $-0,06$ & $-0,02$ & 0,09 & 0,04 & $-0,02$ & $-0,04$ & 0,01 \\
& 0,859 & 0,467 & 0,713 & 0,922 & 0,554 & 0,799 & 0,901 & 0,804 & 0,962 \\
Cond 6 & $-0,12$ & $-0,01$ & 0,13 & $-0,05$ & $-0,20$ & $-0,01$ & $-0,01$ & 0,12 & 0,08 \\
& 0,440 & 0,930 & 0,383 & 0,757 & 0,193 & 0,926 & 0,949 & 0,437 & 0,605 \\
Cond. 7 & $-0,06$ & $-0,08$ & $-0,11$ & $-0,21$ & $-0,15$ & $-0,14$ & $-0,20$ & $-0,21$ & $-0,19$ \\
& 0,677 & 0,622 & 0,458 & 0,152 & 0,305 & 0,366 & 0,184 & 0,157 & 0,204 \\
Cond 8 & 0,06 & 0,13 & 0,05 & 0,07 & $-0,18$ & $-0,04$ & $-0,01$ & 0,01 & 0,01 \\
& 0,683 & 0,391 & 0,752 & 0,661 & 0,245 & 0,805 & 0,976 & 0,979 & 0,977 \\
\hline
\end{tabular}

* Correlação é significante no nível 0.05 (2-tailed).

** Correlação é significante no nível 0.01 level (2-tailed).

Nota: As abreviações IR, PM, IP, AS, FAI, AC, FB e CB, respectivamente, são indicativas dos fatores da SPQ ideias de referência, pensamento mágico, experiências percepetuais incomuns, ideação paranoide, ansiedade social, sem amigos íntimos, afeto constrito, fala bizarra e comportamento bizarro. 
Observa-se correlações entre o fator afeto constrito (SPQ AC) ${ }^{28}$ e as condições 1 (antecedente indefinido, +reforço, leitura de classe) ( $p=.018)$ e 2 (antecedente indefinido, +reforço, leitura de indivíduo) $(p=.041)$. A primeira correlação é negativa e a segunda é positiva. Portanto, participantes com pontuações altas no fator afeto constrito atribuíram notas mais baixas para os itens da condição 1 e notas mais altas para os itens da condição 2 .

\section{FTD-S - Formal Thought Disorder-Self}

A escala FTD-S total teve média igual à $23(\mathrm{DP}=10,0)$ e nas dimensões as médias obtidas foram: (Cf. Tabela 11)

- Dimensão 1 (fala bizarra): 10,5 (DP=4,9),

- Dimensão 2 (habilidade para conversas): 6,2 (DP=3,5),

- Dimensão 3 (memória de trabalho): 6,4 (DP=3,8).

Tabela 11.

Descrição estatística da FTD-S, incluindo média, desvio padrão, máximo e mínimo obtido no modelo de 3 dimensões e total.

\begin{tabular}{lcccc}
\hline & média & desvio padrão & mínimo & máximo \\
\hline FTD-S Total & 23,0 & 10,0 & 3 & 50 \\
Dimensão 1 & 10,5 & 4,9 & 1 & 23 \\
Dimensão 2 & 6,2 & 3,5 & 0 & 13 \\
Dimensão 3 & 6,4 & 3,8 & 0 & 17 \\
\hline
\end{tabular}

$\mathrm{Na}$ análise de correlação entre as dimensões do FTD-S e as condições do teste de linguagem (tabela 12), obtivemos correlação significativa positiva entre a dimensão 2 do FTD-S (habilidade para conversas) e a condição 2 do teste de linguagem (antecedente indefinido, +reforço, leitura de indivíduo) $(p=.016)$.

\footnotetext{
${ }^{28}$ Uma análise de correlação considerando os itens do fator afeto constrito indicou que o fator "Tenho dificuldade de olhar nos olhos das pessoas com quem converso" é o item determinante na correlação com a condição $1(p=.006)$
} 
Tabela 12.

Correlações entre FTD-S (3 dimensões) e as condições do teste de linguagem.

\begin{tabular}{lccc}
\hline & Dimensão1 & Dimensão2 & Dimensão3 \\
\hline Cond. 1 & 0,01 & $-0,15$ & $-0,05$ \\
& 0,932 & 0,319 & 0,752 \\
\hline Cond.2 & 0,03 &, $352^{*}$ & 0,02 \\
& 0,842 & 0,016 & 0,923 \\
\hline Cond 3 & 0,07 & $-0,17$ & $-0,04$ \\
& 0,657 & 0,247 & 0,790 \\
\hline Cond. 4 & 0,01 & 0,00 & $-0,17$ \\
& 0,926 & 0,979 & 0,253 \\
\hline Cond. 5 & 0,04 & 0,22 & 0,12 \\
& 0,815 & 0,142 & 0,418 \\
\hline Cond 6 & 0,17 & 0,02 & $-0,05$ \\
& 0,256 & 0,884 & 0,722 \\
\hline Cond. 7 & 0,01 & $-0,06$ & 0,02 \\
& 0,968 & 0,685 & 0,910 \\
\hline Cond 8 & 0,08 & $-0,01$ & $-0,12$ \\
& 0,582 & 0,960 & 0,435 \\
\hline
\end{tabular}

* Correlação é significante no nível 0.05 (2-tailed).

** Correlação é significante no nível 0.01 level (2-tailed).

Nota: dimensão 1 corresponde ao fator fala bizarra, a condição 2 ao fator habilidade para conversas e a dimensão 3 ao fator memória de trabalho.

Portanto, a correlação obtida entre o fator afeto constrito do SPQ e a condição 2 do teste de linguagem foi obtida também com a dimensão 2 (habilidade para conversas). Ou seja, pontuação mais alta na dimensão 2 do FTD-S (i.e. baixa habilidade para conversas) e no fator afeto constrito do SPQ (i.e. maior constrição de afeto) implica em avaliação mais alta de leitura de indivíduo em contextos ostensivos para leitura de individuo, contextos em que o antecedente é uma expressão indefinida e há reforço contextual.

Dado os resultados obtidos nas correlações com o teste de linguagem, fizemos uma análise de correlação entre o fator afeto constrito no SPQ e habilidade para conservas no FTD. Como esperado, há de fato uma correlação $(p=.001)$.

Tabela 13.

Correlações entre Dimensão do FTD-S e Fator Afeto Constrito do $\mathrm{SPQ}(\mathrm{n}=46)$

\begin{tabular}{lc}
\hline & Correlação \\
\hline SPQ AC \\
\hline \multirow{2}{*}{ FTD-S Dimensão 2 } & $0,692^{* *}$ \\
& 0,001 \\
\hline
\end{tabular}

** Correlação é significante no nível 0.01 level (2-tailed). 
Assim, as correlações aqui encontradas corroboram a validade das escalas psicométricas usadas no experimento.

\subsection{Discussão dos resultados}

Os resultados da nossa investigação podem ser resumidos da seguinte maneira:

- No geral, falantes do PB apresentam preferência significativa por interpretar uma expressão nominal definida como referindo-se a um único indivíduo. Essa preferência, no entanto, cede a uma interpretação de classe (i.e. referência a uma classe de indivíduos) quando o contexto contém pistas ostensivas para leitura de classe.

- Presença de afeto constrito e habilidade diminuida para conversas como traços de personalidade interfere na construção da referência de expressões nominais definidas, de modo a restringir o falante à intepretação de indivíduo em contextos com pistas ostensivas para essa intepretação.

- O domínio de um segundo idioma interfere nas decisões interpretativas dos falantes. Falantes com domínio de outra língua tendem a atribuir avaliações mais altas a leituras de individuo quando a expressão nominal definida está inserida em um contexto de fala em que o antecedente de referência é um nome indefinido.

A preferência significativa por uma leitura de indivíduo demonstra que falantes adultos do PB apresentam forte pressuposição de unicidade na construção da referência de expressões nominais definidas. Mesmo quando o contexto dado é favorável a uma leitura de classe, esta pressuposição é mantida, já que as avaliações para a leitura de indivíduo não são baixas nas condições em que antecedente é um nome nu.

Os resultados obtidos estão, portanto, de acordo com a nossa análise para a construção linguística da referência de expressões nominais definidas (ver capítulo 3, seção 3.3). A pressuposição de unicidade inerente ao artigo definido privilegia a escolha de um referente único. Esta pressuposição, no entanto, é suspensa quando o contexto de fala indica não se tratar de um único indivíduo, mas de uma classe de indivíduos. Portanto, em contextos com informações ostensivas para leitura de classe, observamos uma não preferência pela leitura de indivíduo. Isto é, falantes de PB são sensíveis as pistas contextuais que indicam 
suspensão da pressuposição de unicidade.

Corroborando a análise estatística apresentada, fizemos também uma análise das médias dos valores atribuídos para cada condição e concluímos que no geral os valores atribuídos à leitura de indivíduo em contextos contendo nome nu como antecedente são bem mais altos do que os valores atribuídos à leitura de classe em contextos contendo expressão nominal indefinida como antecedente. Portanto, há de fato uma manutenção da pressuposição de unicidade mesmo quando o contexto dá pistas de que se trata de uma classe de indivíduos.

Em resumo, concluímos com base na literatura sobre definitude (ver, cap. 3, em especial Roberts (2003), Abott (2006) e Longchamps (2014)) e nos resultados por nós obtidos, que a avaliação da leitura de individuo pode ser feita com base apenas na informação semântica/lexical do artigo definido. A leitura de classe, por sua vez, requer uma avaliação pragmática do contexto (gramatical e discursivo) para verificar se é necessário uma quebra da pressuposição de unicidade.

Dado que a nossa amostra foi pequena, especialmente no que tange ao grupo de indivíduos com pontuações altas nas escalas psicométricas, o que apresentamos aqui são resultados preliminares sobre a relação entre presença de traços de esquizotipia e escolhas de referentes para conceitos linguísticos. Contudo, as correlações encontradas, embora sejam fracas, indicam que falantes com pontuação mais altas no fator afeto constrito (SPQ) e na dimensão (pouca) habilidade para conversas (FTD-S) são mais restritivos em suas escolhas de referentes para expressões nominais definidas, apresentando preferência marcada por leitura de indivíduo, especialmente em contextos ostensivos para essa leitura ${ }^{29}$.

Essas correlações são inesperadas dado o que é relatado na literatura sobre integração de pistas contextuais. Como discutido no capítulo 2 (ver seção 2.3), a literatura informa que o construto da esquizotipia (em especial a esquizofrenia) apresenta dificuldades com referência linguística, especialmente no que tange à integração de pistas contextuais (e.g. Docherty et al., 2003; Kuperberg, 2010;

\footnotetext{
${ }^{29}$ Um análise das médias dos dados brutos para cada condição revelou uma sensibilidade um pouco maior por parte desses falantes à presença do fator reforço contextual. Ou seja, em comparação com os outros participantes, para estes participantes, a ligação da expressão nominal ao antecedente dado discurso foi maior nas condições em que havia reforço. Uma investigação cuidadosa desta questão em amostra maior é necessária para que possamos considerar este achado.
} 
Ettinger et al., 2015). Assim, na investigação conduzida, esperávamos que as escolhas de interpretação das expressão nominais definidas fossem pouco coerentes com o contexto dado. Isto é, nossa previsão era que indivíduos com pontuações mais altas nos fatores da escala SPQ e nas dimensões da FTD-S apresentassem dificuldades de integração das pistas contextuais na construção da referência das expressões nominais dadas. Essa dificuldade não foi encontrada. No entanto, é importante observar que os estudos anteriores (ver capítulo 2) sobre dificuldades na contextualização da referência relatam associações com itens positivos da FTD, como aceleração de fala, perda de objetivo, descarrilamento, tangencialidade e neologismos. Os itens negativos da FTD estão relacionados a expressão emocional diminuída, como redução no contato visual e na entonação da fala, e principalmente com alogia, produção diminuída do discurso (Andreasen, 1979; Ott et al. 2002; APA, 2014). O fator afeto constrito da escala SPQ e a dimensão (pouca) habilidade para conversas da FTD-S são, portanto, traços negativos de esquizotipia. Por isso, é natural que os nossos resultados apontem na direção oposta do que é relatado na literatura.

Assim, mesmo que ainda de maneira preliminar, a nossa investigação indica que indivíduos com traços negativos de personalidade esquizotípica tendem a ficar mais presos ao contexto de fala. $\mathrm{Na}$ interpretação de expressões nominais definidas, se o contexto é ostensivamente a favor da manutenção da pressuposição de unicidade, falantes com traços negativos de esquizotipia tendem a não suspender esta pressuposição.

Como um próximo passo da nossa investigação, aumentaremos a nossa amostra inicial com o objetivo de verificar de maneira detalhada como traços positivos e negativos no construto da esquizotipia podem afetar a construção da referência de expressões definidas no âmbito da linguagem.

A correlação entre ter domínio de uma segunda língua e ter preferência por leituras de indivíduo em contextos ostensivos para esta leitura é uma questão importante porque nos informa sobre a necessidade de se controlar variáveis do background social e linguístico do participante em pesquisas na área de linguística. A maioria dos participantes declarou ser falante de inglês ${ }^{30}$. Em

\footnotetext{
${ }^{30} 93 \%$ dos participantes declararam falar outro idioma. Desses, $58 \%$ declararam o inglês e outro , $40 \%$ somente o inglês e $2 \%$ somente espanhol. Observamos novamente que nenhum participante declarou ser bilíngue.
} 
inglês, a leitura de classe é compatível tanto com expressões definidas no singular como com expressões de nome nu no plural (bare plurals), como exemplificado em (1) e (2):

(1) The polar bear is dangerous.

(2) Polar bears are dangerous.

No entanto, estudo experimental comparativo entre inglês e PB (Ionin et al., 2011) mostra que há no inglês preferência significativa pelo uso de nomes nus no plural (2) para expressar leitura de classe. Em contraste, no PB a leitura de classe é preferencialmente feita por expressões nominais definidas no plural (3). Ou seja, tanto em inglês com em português a leitura de classe é preferencialmente realizada pela marcação morfológica de número plural dentro a expressão nominal.

(3) Os ursos polares são perigosos.

Dada a correlação encontrada na nossa investigação, consideramos uma possível interferência do inglês nos resultados obtidos. Falantes com domínio do inglês apresentaram preferência mais acentuada por uma interpretação de indivíduo por relacionarem leituras classe à marca de plural especialmente em contextos que reforçam a leitura de indivíduo. Devido a um reforço da língua inglesa, é provável que para esses falantes, a leitura de classe seja realizada via marcação de número plural na expressão nominal. Infelizmente, como a nossa amostra foi pequena e $93 \%$ dos participantes declarou ser falante de uma segunda língua, não é possível uma análise por grupo para verificar melhor a correlação encontrada e a análise sugerida. De qualquer forma, registramos aqui um possível caso de transferência reversa da segunda língua para a primeira (Jarvis \& Pavlenko, 2008). 


\section{Considerações finais}

Nesta dissertação, realizamos estudo experimental sobre o papel do contexto de fala na construção da referencialidade de expressões nominais definidas no português brasileiro (PB). Buscamos verificar em que medida jovens adultos falantes nativos do PB são sensíveis (ou não) a pistas contextuais para estruturação de relações anafóricas dentro do contexto discursivo. Além disso, procuramos identificar, de maneira preliminar, possíveis correlações entre traços de personalidade esquizotípica e alterações na construção da referência de conceitos linguísticos. Ou seja, buscamos investigar em que medida e de que maneira esses traços podem afetar a integração das pistas contextuais para a construção da referencialidade linguística, em especial a referencialidade de expressões nominais definidas.

No capítulo 1, apresentamos as hipóteses e as perguntas que nortearam nossa investigação, levantamos algumas questões pertinentes à esquizofrenia, bem como a importância de investigarmos a linguagem nas desordens mentais. Salientamos, ainda, a necessidade de ampliarmos os estudos sobre linguagem na esquizotipia, principalmente em indivíduos sem quadro clínico, na medida em que podem ser informativos sobre vulnerabilidade à doença e sobre questões relacionadas à linguagem como função cognitiva.

No capítulo 2, traçamos um panorama da esquizofrenia/esquizotipia, focando nos distúrbios de linguagem observados. Nos debruçamos não só sobre a caracterização, mas também sobre problemas relacionados ao diagnóstico da doença, salientando o importante papel da linguagem nesse cenário. Trouxemos exemplos de estudos apontando que esquizofrênicos apresentam diferenças pontuais em áreas do cérebro quando comparados a indivíduos normais, e que indivíduos com TEP (e outras esquizotipias) apresentam padrões similares. Tais estudos corroboram o entendimento da doença mental enquanto parte de um continuo de amplo espectro que se estende desde indivíduos saudáveis até quadros graves de psicose.

No capítulo 3, mostramos que a perspectiva biológica da linguagem, enquanto função cognitiva unicamente humana, admite dois entendimentos sobre a arquitetura da mente. Entretanto, salientamos que ainda não há, no momento, como ser resolvida a questão quanto a linguagem ser um domínio específico ou 
geral. Entendo que doenças mentais que afetam o pensamento e a linguagem podem ser informativas sobre especificidade de domínios dentro da cognição, lançamos a proposta de verificar experimentalmente a construção da referencialidade de expressões nominais definidas em indivíduos com baixa e alta expressão de traços de esquizotipia. Assim, ainda no capítulo 3, demos ênfase ao entendimento teórico dentro dos estudos da semântica formal sobre definitude, especialmente no que tange às condições de unicidade e familiaridade, questões linguísticas fundamentais para a nossa pesquisa, e apresentamos evidências de estudos anteriores de que falantes esquizotípicos e esquizofrênicos apresentam problemas na construção da referência de expressões definidas por não observar as condições de unicidade e familiaridade. Uma questão importante que esses estudos mostram é que pacientes com esse tipo de desordem têm dificuldade na integração de pistas contextuais para a construção da referência linguística. Levantamos, portanto, com base em uma análise comparativa com estudos realizados com crianças saudáveis, a possibilidade da esquizotipia/esquizofrenia apresentarem distúrbios linguísticos de pragmática.

No capítulo 4, apresentamos o estudo experimental que conduzimos, buscando verificar: (a) a integração de pistas contextuais na construção da referência de expressões nominais definidas em falantes adultos do PB e (b) correlações entre traços de esquizotipia e alterações na integração das pistas contextuais em questão. $\mathrm{O}$ resultados revelaram que no geral falantes de PB têm preferência significativa por interpretar uma expressão nominal definida como referindo-se a único indivíduo, embora referência a classes de indivíduos seja possível quando o contexto contém pistas ostensivas de que a expressão nominal refere-se a uma classe de indivíduos. Discutimos estes resultados, e sugerimos, com base em nossa análise sobre as condições de unicidade e familiaridade, que artigos definidos em PB pressupõem inerentemente a unicidade da entidade referida. Essa pressuposição só é suspensa quando a pragmática (contexto de uso) força sua suspensão. Portanto, no geral falantes de PB são sensíveis ao significado semântico de expressões nominais definidas (pressuposição de unicidade), mas são também sensíveis a fatores pragmáticos, fazendo ajustes ao significado semântico sempre que o contexto de uso pede algum tipo de acomodação pragmática. 
Nossos resultados apontam também que fatores negativos das escalas de esquizotipia (fator afeto constrito) e FTD-S (fator habilidade para conversas) aumentam a sensibilidade à pressuposição de unicidade em contextos que indicam de maneira ostensiva que a pressuposição em questão deve ser mantida. Desse modo, consideramos, ainda que de maneira preliminar, que a presença de traços negativos de esquizotipia aumenta a sensibilidade do falante às pistas fornecidas pelo contexto para a construção da referência. Salientamos que nossos resultados são opostos aos resultados relatados na literatura sobre esquizotipia e esquizofrenia, e consideramos que esse contraste pode estar relacionado ao fato de termos detectado traços negativos de esquizotipia entre participantes da pesquisa, enquanto a literatura relata, em sua maioria, presença de traços positivos.

A pesquisa que aqui iniciamos abre caminhos para vários desdobramentos e investigações futuras. Como mencionado, fizemos uma investigação preliminar, um primeiro passo de uma pesquisa sobre a relação entre perfis esquizotípicos não clínicos e a construção da referencialidade linguística. Em um segundo momento, pretendemos aumentar nossa amostra de modo que se torne possível trabalhar com diferentes grupos dentro do construto da esquizotipia. A pesquisa entre grupos pode ajudar à identificação de questões mais refinadas na construção da referencialidade, possibilitando um melhor entendimento dos resultados encontrados e maior poder de generalização. Além disso, pretendemos, paralelamente, expandir a pesquisa para englobar pacientes esquizofrênicos e seus familiares, grupo esquizotípico em potencial (Lenzenweger, 2006, 2015).

Enfim, acreditamos que este foi um primeiro passo investigativo, com algumas contribuições para a área de estudos da linguagem e outras áreas do conhecimento, especialmente para a caracterização de questões da linguagem no construto da esquizotipia. 


\section{Referências bibliográficas}

ABBOTT, B. Definite and Indefinite. In Keith Brown (ed.) Encyclopedia of Language and Linguistics. Elesevier. Pp. 3-392 (2006).

AMERICAN PSYCHIATRIC ASSOCIATION: Manual diagnóstico e estatístico de transtornos mentais, $5^{\mathrm{a}}$. edição (DSM-V). Washington, DC: American Psychiatric Association. Trad.: Maria Inês Corrêa Nascimento et al, revisão técnica: Aristides Volpato Cordiolo et al. Porto Alegre. Artmed, 2014, 948p. ISBN978-85-8271-08803.

ANDREASEN, N.C. Thought, language, and communication disorders: I. Clinical assessment, definition of terms, and evaluation of their reliability. Archives of General Psychiatry, 36:1315-1321, 1979.

ANDREASEN, N., \& GROVE, W. (1986). Thought, language and communication in schizophrenia: diagnosis and prognosis. Schizophrenia Bulletin 2, 348-359.

ANDREASEN, N.C. \& BLACK, D.W. Introdução à psiquiatria. Trad. Lopes, M.F. \& Doreneles, C. (4a. ed) Porto Alegre: Artmed, 2009.

ANSElMETTI, S., BECHI, M., BOSIA, M., QUARTICELli, C., ERMOLI, E., SMERALDI, E., et al. (2009). Theory of mind impairment in parents of patients affected by schizophrenia. Schizophr. Res. 115, 278-285.

ASARNOW, J. R., STEFFY, R. A., MACCRIMMON, D. J., \& CLEGHORN, J. M. (1978). An attentional assessment of foster children at risk for schizophrenia. In L. C. Wynne, R. L. Cromwell, \& S. Matthysse (Eds.), The nature of schizophrenia: New approaches to research and treatment (pp. 339-358). New York: Wiley.

BARIN, N. R. Teoria da Relevância e compreensão de textos publicitários. Revista eletrônica: Vidya, v. 19, n. $35 \quad$ (2001). Disponível em http://www.periodicos.unifra.br/index.php/VIDYA/article/view/501

BARRANTES-VIDAL, N., GRANT, P., e KWAPIL, T.R. The Role of Schizotypy in the Study of the Etiology of Schizophrenia Spectrum Disorders. Schizophrenia Bulletin. Vol. 41 suppl. no. 2 pp. S408-S416, 2015.

BARRERA, A., MCKENNA, P. J., \& BERRIOS, G. E. (2004). Formal thought disorder in schizophrenia: an executive or a semantic deficit? Psychol. Med. 35, 121-132.

BARRERA, A., HANDEL, A., KONDEL, T. \& LAWS, K. Formal Thought Disorder: Self-report in Non-clinical Populations. International Journal of Psychology and Psychological Therapy, 2015, 15, 1, 155-167.

BARWISE, J. \& COOPER, R. Generalized quantifiers and natural language. Linguistics and Philosophy 4 (2):159—219 (1981). 
BERLIM, M., MATTEVI, B.S., BELOMONTE-DE-ABREU, P. e CROW, T.J. The etiology of schizophrenia and the origin of language overview of a theory. Comprehensive psychiatry, Vol. 44, No. 1 ( January/February), 2003: pp 7-14.

BERWICK, C.R., CHOMSKY, N. (2015) Why only us? MIT Press. Cambridge, Massachusetts.

BERWICK, C.R., FRIEDERICI, A.D., CHOMSKY, N. \& BOLHUIS, J. Evolution, brain, and the nature of language. Trends and Cognition Sciences (2013) Feb;17(2):8998.

BICKERTON, D. (2003) Symbol and structure: a comprehensive framework for language evolution. In M.H. Christiansen and S. Kirby, editors, Language Evolution: The States of the Art. Oxford University Press.

BLEULER, E. Dementia praecox; or the group of schizophrenias. New York: International Universities Press, 1950. (Originally published, 1911).

BOECKX, C. Review: Un-cartesian (bio-)linguistics? : The philosophy of universal grammar by Wolfran Hinzen, Michelle Sheenan. Teorema Revista Internacional de Filosofia Vol. 34, No.1 (2015) pp.161-186.

BOLHUIS, J., TATTERSALL, I., CHOMSKY, N \& BERWICK, R.C. (2014) How could language have evolved? PLoS Biol 12(8): e1001934.

BORA, E., \& PANTELIS, C. (2013). Theory of mind impairments in first-episode psychosis, individuals at ultra-high risk for psychosis and in first-degree relatives of schizophrenia: systematic review and meta-analysis. Schizophr. Res. 144, 31-36. doi:10.1016/j.schres.2012.12.013.

BRÜNE, M. Schizophrenia - an evolutionary enigma? Neuroscience and Biobehavioral Reviews 28 (2004) 41-53 Received 14 July 2003; accepted 23 October 2003.

BRÜNE, M. 'Theory of mind' in schizophrenia: A review of the literature. Schizophr Bull. 2005; 31:21- 42 .

BRÜNE M, \& BODENSTEIN L. Proverb comprehension reconsidered; 'theory of mind' and the pragmatic use of language in schizophrenia. Schizophr Res. 2005; 75:233-239.

BUEHLER, K. (1934). Sprachtheorie. D. W. Goodwin, Trans. (1990). Theory of language: The representational function of language. Amsterdam: J Benjamins.

BUCHSBAUM MS, TANG CY, PELED S, GUDBJARTSSON H, LU D, HAZLETT EA, et al. (1998): MRI white matter diffusion anisotropy and PET metabolic rate in schizophrenia. Neuroreport 9:425-430. 
CAllawAY, D. A., COHEN, A. S., \& MATTHEWS, R. A., Schizotypal Personality Questionnaire - Brief Revised: Psychometric Replication and Extension. Personality Disorders: Theory, Research, and Treatment 2014, Vol. 5, No. 1, 32-38 American Psychological Association.

CARLSON, G. N. (1977). A unified analysis of the English bare plural. Linguistics and philosophy, 1(3), 413-457.

CARSTAIRS-MCCARTHY, A. Language evolution: what linguistics can contribute. Lingua, vol. 117:3; 503-509. March 2007.

CHAIKA E. A linguist looks at "schizophrenic" language. Brain Lang (1974) 1:257276.

CHAIKA E. A unified explanation for the diverse structural deviations reports for adult schizophrenics with disrupted speech. Journal of Communication Disorders 15 (1982), 167-189.

CHAIKA, E. \& LAMBE, R. A. (1989). Cohesion in schizophrenic narratives, revisited. Journal of Communication Disorders, 22, 407-421.

CHAMPAGNE-LAVAU, M., FOSSARD, M., MARTEL, G., CHAPDELAINE, C., BLOUIN, G., RODRIGUEZ, J.P. E STIP, E. DO patients with schizophrenia attribute mental states in a referential communication task? Cognitive Neuropsychiatry 14, Issue 3, 217-239 (2009).

CHAPMAN, J., 1966. The early symptoms of schizophrenia. Br. J. Psychiatry 112, $225-251$.

CHEN, R.Y.L., 1996. Language disorganisation in schizophrenia: validation and assessment with a new clinical rating instrument. Hong Kong J. Psychiatry 6 (1), 4-13.

CHIEN, Y. \& WEXLER, K. (1990) Children's knowledge of locality conditions in binding as evidence for the modularity of syntax and pragmatics. Language Acquisition, $1,225-295$.

CHIERCHIA, G. 1995. Individual level predicates as inherent generics. In: CARLSON, G. N.; PELlETIER, P. J. (Eds.). The Generic Book. Chicago: The University of Chicago Press, p. 176-223.

CHOMSKY, N. Lectures on government and binding: the Pisa lectures. Berlin; New York: Mouton de Gruyter (1981).

CHOMSKY, N. Knowledge of language: nature, origin and use. New York, NY: Praeger Publishers (1986). 
CHOMSKY, N. The minimalist program. Cambridge, Massachusetts; London, England: The MIT Press (1995).

CHOMSKY, N. Linguagem e mente. (Trad.) Lúcia Lobato. Brasília: Editora Universidade de Brasília (1998).

CHOMSKY, N. Novos horizontes no estudo da linguagem e da mente. (Trad.) Sant'Anna, M.A. - São Paulo: Ed. UNESP (2002).

CHOMSKY, N. On Phases. Ms.: MIT (2005a).

CHOMSKY, N. Three Factors in Language Design Linguistic Inquiry, Volume 36, Number 1, Winter 2005 1-22 (2005b) by the Massachusetts Institute of Technology.

CHOMSKY, N. Sobre natureza e linguagem. (Org.) Belleti, A. e Rizzi, L. (Trad.) Michael, M.P. - São Paulo: Martins Fontes (2006).

CHOMSKY, N. Of minds and language. Biolinguistics 1(1), p. 9-27, 2007.

CHOMSKY, N. 2009. Cartesian linguistics: a chapter in the history of rationalist thought. Cambridge: Cambridge University Press.

CHOMSKY, N. \& MCGILVRAY, J. The Science of Language: interviews with James McGilvray / Noam Chomsky. Noam Chomsky \& James McGilvray (Eds) (2012).

CLARK, H. (1975) Bridging. In: Theoretical issues in natural language processing. R.C. \& B.L. Nash-Webber (eds), 9-27. New York, NY: Association for Computing Machinery.

COHEN, A. S., MOHR, C., ETTINGER, U., CHAN, RAYMOND C. K., \& PARK, S. Schizotypy as an Organizing Framework for Social and Affective Sciences. Schizophrenia Bulletin vol. 41 suppl. no. 2 pp. S427-S435, 2015.

CONDRAY R, STEINHAUER SR, GOLDSTEIN G, et al. Language comprehension in schizophrenics and their brothers. Biol Psychiatry 1992;32:790-802.

CORCORAN. R., MERCER, G., \& FRITH CD. Schizophrenia, symptomatology and social inference: Investigating 'theory of mind' in people with schizophrenia. Schizophr Res. 1995; 17:5-13.

CORREAA, L. M. S. O DEL à luz de hipóteses pisco/linguísticas: Avaliação de habilidades linguísticas e implicações para uma possível intervenção em problemas de linguagem de natureza sintática. Veredas Online - Especial - 2012, p. 207-236 PPG Linguística/UFJF - Juiz de Fora - ISSN 1982-2243. 
CORRÊA, L. M. S.; AUGUSTO, M. R. A.; ANDRADE-SILVA, H. M. Definitude e genericidade na aquisição do Português Brasileiro (PB): interface gramática e pragmática. In: XV Congreso Internacional de la Associación de Linguistica e Fillologia de América Latina (ALFAL), Montevidéu, 2008.

COSTA, J. \& AMBULAT, J. 2010. The acquisition of embedded subject pronouns in European Portuguese. In Michael Iverson et al. (eds.). Proceedings of the 2009 Mind/Context Divide Workshop. Somerville, MA: Cascarilla Press, p. 1-12.

COVINGTON, M.A., HE, C., BROWN, C., NAÇI, L., MCCLAIN, J.T., FJORDBAK, B.S., et al. Schizophrenia and the structure of language: the linguist's view. Schizophr Res. 2005;77:85-98. Epub 2005 Apr 2.

CRAIG JS, HATTON C, CRAIG FB, BENTALL RP. Persecutory beliefs, attributions and theory of mind: comparison of patients with paranoid delusions, Asperger's syndrome and healthy controls. Schizophr Res. 2004; 69:29-33.

CROW, TJ. Temporolimbic or transcallosal connections: where is the primary lesion in schizophrenia and what is its nature? Schizophrenia Bulletin (1997a);23:521 - 3 .

CROW, TJ. (1997b). Schizophrenia as failure of hemispheric dominance for language. Trends Neuroscince. 20, 339-343.

CROW, TJ. Nuclear schizophrenic symptoms as a window on the relationship between thought and speech. Br J Psychiatry (1998a);173: 303-9.

CROW, TJ. Precursors of psychosis as pointers to the Homo sapiens-specific mate recognition system of language. Br J Psychiatry (1998b), 172, 289-290.

CROW, TJ. Schizophrenia as the price Homo sapiens pays for language: a resolution of the central paradox in the origin of the spicies. Brian Research Review 31, Apr. 2000 118-129.

CROW, TJ. Asymetrix cerebral e lateralização da linguagem: déficits nucleares na esquizofrenia como indicadores de predisposição genética, Revista de Psiquiatria. RS, 26 (2): 122-134, mai./ago. (2004a).

CROW, TJ. Auditory hallucinations as primary disorders of syntax: An evolutionary theory of the origins of language. Cognitive Neuropsychiatry, (2004b), 9 1/2, 125-145.

CROW, TJ. The 'big bang' theory of the origin of psychosis and the faculty of language. Schizophrenia Research 102 (2008) 31-52. Elsevier B.V.

CROW, TJ. The nuclear symptoms of schizophrenia reveal the four quadrant structure of language and its deictic frame. Journal of Neurolinguistics 23 (2010) 1-9. 
DA SILVA, R.C.B. Esquizofrenia: uma revisão. Psicologia USP, v. 17, n. 4, p. 263285, 2006.

DAVIDSON, C. A., HOFFMAN, L., SPAULDING, W. D. Schizotypal personality questionnaire - brief revised (updated): An update of norms, factor structure, and item content in a large non-clinical young adult sample. (2016) Elsevier Ireland Ltd.

DAYAL, V. 2011. Bare Noun Phrases. In Maeinborn, von Heusinger and Portner (eds), Semantics: An International Handbook of Natural Language Meaning 1087-1108.

DE VILLIERS, J. (2000). Language and theory of mind: What are the developmental relationships. In S. Baron-Cohen, H. Tager-Flusberg, \& D. Cohen (Eds.), Understanding other minds: Perspectives from developmental cognitive neuroscience. Second Edition, (pp. 83-123). Oxford: Oxford University Press.

DEBBANÉ, M. \& BARRANES-VIDAL, N. Schizotypy From a Developmental Perspective. Schizophrenia Bulletin vol. 41 suppl. no. 2 pp. S386-S395, 2015.

DICKEY, C.C., MCCARLEY, R.W., VOGLMAIER, M.M., NIZNIKIEWICZ, M.A., SEIDMAN, L.J., HI-RAYASU, Y., FISCHER, I., THE, E.K., VAN RHOADS, R., JAKAB, M., KIKINIS, R., JOLESZ, F.A., SHEN-TON, M.E. Schizotypal personality disorder and MRI abnormalities of temporal lobe gray matter. Biol Psychiatry. 1999;45(11):1393-1402.

DITMAN, T. \& KUPERBERG, G.R. Building coherence: A framework for exploring the breakdown of links across clause boundaries in schizophrenia Published in final edited form as: J Neurolinguistics. 2010 May 1; 23(3): 254-269.

DOBROVIE-SORIN, C., OLIVEIRA, R.P., Reference to kinds in Brazilian Portuguese: the definite singular vs. bare singulars. In: GRØNN, Atle (Ed.). Proceedings of SuB12, Oslo: ILOS 2008.

DOCHERTY, NM. Cognitive impairments and disordered speech in schizophrenia: Thought disorder, disorganization, and communication failure perspectives. Journal of Abnormal Psychology. 2005; 114:269-278.

DOCHERTY, N.M.; COHEN, A., NIENOW, T.M., DINZEO, T.J., e DANGELMAIER, R.E. Stability of formal thought disorder and referential communication disturbances in schizophrenia. Journal of Abnormal Psychology, 2003, vol. 112, No. 3, 469-475.

DOCHERTY, N. M., GORDINIER, S. W., HALL, M. J., \& CUTTING, L. P. (1999). Communication disturbances in relatives beyond the age of risk for schizophrenia. Schizophrenia Bulletin, 25, 851-862.

DOCHERTY, N.M., GORDINIER, S.W., HALL, M.J., \& DOMBROWSKI, M.E. (2004) Referential communication disturbances in the speech of nonschizophrenic siblings of schizophrenia patients. Journal of Abnormal Psychology, 113, 399-405. 
DOCHERTY, N.M. \& GOTTESMAN, I. (2000). A twin study of communication disturbances in schizophrenia. Journal of Nervous and Mental Disorders, 188, 395401.

DOCHERTY, N. M., HALL, M. J., GORDINIER, S. W., \& CUTTING, L. P. (2000). Conceptual sequencing and disordered speech in schizophrenia. Schizophrenia Bulletin, 26, 723-735.

DOCHERTY, N.M., HAWKINS, K.A., HOFFMAN, R.E., QUINLAN, D.M., RAKFELDT, J. and SLEDGE, W.H. (1996). Working memory, attention, and communication disturbances in schizophrenia. Journal of Abnormal Psychology, 105, 212-219.

DONNELLAN, K. 1997. Reference and Definite Descriptions. In P. Ludlow. (Ed.) Readings in the philosophy of language. The MIT Press. 361-381.

ELKIS, H. A evolução do conceito de esquizofrenia neste século, Revista Braileira de Psiquiatria 2000;22 (Supl I):23-6.

ENÇ, M. 1991. The semantics of specificity. Linguistic inquiry 22: 1-25.

ETTINGER, U., MEYHÖFER, I., STEFFENS, M., WAGNER, M. E KOUTSOULERIS, N. Genetics, cognition, and neurobiology of schizotypal personality: a review of the overlap with schizophrenia, Frontiers Psychology February 2014, vol. 5, article 18.

ETTINGER, U., MOHR, C., GOODING, D.C. et al. Cognition and brain function in schizotypy: a selective review. Schizophr Bull. 2015;41(suppl 2):S417-S426.

FERREIRA, M. \& C. N. CORREIA. 2016. The semantics of DPs. In W. L. Wetzels, J. Costa and S. Menuzzi (eds.) The Handbook of Portuguese Linguistics, John Wiley \& Sons, Inc, Hoboken. 356-373.

FITCH, W. The Evolution of Language. Cambridge University Press (2010).

FITCH, W. T., HAUSER, M. D. e CHOMSKY, N. The Evolution of Language Faculty: clarifications and implications. Cognition 97(2):179-210 (2005).

FODOR, J. A. The Language of Thought. Cambridge (Mass): Harvard University Press, 1975.

FODOR, J. A. The Modularity of Mind. Cambridge (Mass): The MIT Press, 1983.

FONSECA-PEDRERO, E., MUÑIZ, J., LEMOS-GIRÁLDEZ, S., GARCÍA-CUETO, E., CAMPILLO-ÁLVAREZ, A. \& VILLAZÓN GARCÍA, U. Multidimensionality of Schizotypy under review. Papeles del Psicólogo, 2007. Vol. 28(2), pp. 117-126. 
FONSECA-PEDRERO, E., PAÍNO-PIÑEIRO, M., LEMOS-GIRÁLDEZ, S., VILLAZÓN-GARCÍA, Ú. \& MUÑI, J. Validation of the Schizotypal Personality Questionnaire-Brief Form in adolescents. Schizophrenia Research 111 (2009) 53-60.

FRANÇA, Aniela Improta; MAIA, Marcus. Entrevista: Wolfram Hinzen. Revista Linguística / Revista do Programa de Pós-Graduação em Linguística da Universidade Federal do Rio de Janeiro. Volume 11, número 1, junho de 2015, p. 20-27. ISSN 2238975X 1. [http:// www.letras.ufrj.br/poslinguistica/revistalinguistica] DOI: 10.17074/2238975X.2015v11n1p20.

FREGE, G. 1892, 'On concept and object,' reprinted in B. McGuiness (ed.), Collected Papers on Mathematics, Logic, and Philosophy, Oxford: Blackwell, 1984: 182-194.

FRITH, C. D., \& CORCORAN, R. (1996). Exploring 'theory of mind' in people with schizophrenia. Psychol. Med. 26, 521-530.

GRANT, P. (2015). Is Schizotypy per se a suitable endophenotype of schizophrenia? - do no forget to distinguish positive from negative facts. Frontiers in Psychiatry 6:143. doi: 10.3389/fpsyt.2015.00143.

GRICE, H.P. (1957). "Meaning”, Philosophical Review, 66(3). Reprinted as ch.14 of Grice 1989, pp. 213-223.

GORDINIER, S.W., DOCHERTY, N. M. Factor analysis of the communication disturbances index. Psychiatric Res. 2001 Feb 14; 101 (1):55-62.

GROLLA, E. (2010) Remarks on the Acquisition of Intensified Proforms in Brazilian Portuguese. In Proceedings of the First International Psycholinguistics Meeting of ANPOLL. Rio de Janeiro, RJ: Imprinta, p. 75-90.

GRUZELIER, J. The factorial structure of schizotypy: Part I. Affinities with syndromes of schizophrenia. Schizophrenia Bulletin, 22(4):611-621, 1996.

HALLE, C.M., TAGER-FLUSBERG, H. The influence of language on Theory of Mind: a training study. Dev. Sci. 2003 June; 6(3): 346-359.

HARVEY, P. D., WEINTRAUB, S., \& NEALE, J. M. (1982). Speech competence of children vulnerable to psychopathology. Journal of Abnormal Child Psychology, 10, 373-388.

HAUSER, M.D., CHOMSKY, N. \& W. FITCH, T. (2002). The Faculty of Language: what is it, who has it, and how did it evolve? In: Science 298, 1569-1579.

HAUSER, M. D., YANG, C., BERWICK, R. C., TATTERSALL, I., RYAN, M. J., WATUMULL, J., CHOMSKY, N. e LEWONTIN, R. C. The Mysterry of Language 
Evolution. Frontiers in Psychology vol. 5, art. 401 (2014) doi: 10.3389/fpsyg.2014.00401.

HEIM, I. The semantics of the definite and indefinite noun phrases. Dissertation, UMass Amherst (1982).

HEIM, I. \& KRATZER, A. Semantics in generative grammar. Blackwell Publishing (1998).

HERMER-VAZQUEZ, L., SPELKE, E. S. e KATSNELSON, A. S. Sources of Flexibility in Human Cognition: Dual-Task Studies of Space and Language. Cognitive Psychology 39, 3-36 (1999).

HEROLD R, TENYI T, LENARD K, TRIXLER M. Theory of mind deficit in people with schizophrenia during remission. Psychol Med. 2002; 32:1125-1129.

HESPOS, S. J., \& SPELKE, E. S. (2004). Conceptual precursors to language. Nature, 430, 453-456.

HINZEN, W. Emergence of a systemic semantics through minimal and underspecified codes. Biolinguistics: Language Evolution and Variation, Venice (2007).

HINZEN, W. Human Nature and Grammar. Philosophy (Royal Institute of Philosophy Supplement 70), 70, 53-82; (2012).

HINZEN, W. What is un-cartesian linguistics? Biolingusitics 8: 226-22, 2014.

HINZEN, W. Nothing is hidden: contextualism and the grammar-meaning interface. Mind language. 30 (3). pp 259-291; (2015).

HINZEN, W. \& ROSSELLÓ, J. The linguistics of schizophrenia: thought disturbance as language pathology across positive symptoms. Front. Psychol. 6:971. doi:10.3389/fpsyg.2015.00971; (2015).

HINZEN, W. \& SHEEHAN, M. Moving Towards the Edge. Linguistic Analysis, 3(3-4), 405-458; (2011).

HINZEN, W. \& SHEEHAN, M. The Philosophy of Universal Grammar. Oxford University Press (2013).

HOFFER, A. Schizophrenia: an evolutionary advance. Orthomolecular Psychiatry, vol.2, No. 1 and 2, 1973, p 39-65.

HONEA, R., CROW, T.J., PASSINHAM, D. e MACKAY, C.E. Regional deficits in brain volume in schizophrenia: a meta-analysis of voxel-based morphometry studies. American Journal of Psychiatry 162:12, 2233-2245. December, 2005. 
HUXLEY, J., MAYR, E., OSMOND, H., \& HOFFER, A. (1964). Schizophrenia as a genetic morphism. Nature, 204, 220-221.

IONIN, T., MONTRUL, S., SANTOS, H. An experimental investigation of the expression of genericity in English, Spanish and Brazilian Portuguese. Lingua 121 (2011) 963-985.

JABLENSKY, A., SARTORIUS, N., ERNBERG, G., ANKER, M., KORTEN, A., COOPER, J.E., DAY, R., BERTELSEN, A., 1992. Schizophrenia: manifestations, incidence and course in different cultures. A World Health Organization Ten Country Study. Psychol. Med. (Suppl 20), 1-97.

JARVIS, S. \& PAVLENKO, A. (2008). Crosslinguistic Influence in Language and Cognition. New York: Routledge.

JOHNSTONE, E.C., EBMEIER, K.P., MILLER, P., OWENS D.G.C. e LAWRIE. S.M., Predicting schizophrenia: findings from the Edinburgh High-Risk Study, $\mathbf{B r} \mathbf{J}$ Psychiatry (2005), 186, 18-25.

KADMON, N. Uniqueness. Linguistics and Philosophy 13 (3):273-324 (1990).

KARMIRLOFF-SMITH, A. A functional approach to child language: a study of determiners and reference. Cambridge: Cambridge University Press, 1979.

KIANG M, KUTAS M, LIGHT GA, BRAFF DL. An event-related brain potential study of direct and indirect semantic priming in schizophrenia. The American Journal of Psychiatry. 2008; 165:74-81.

KIANG, M. (2010). Schizotypy and language: A review. Journal of Neurolinguistics, 2010, 23, 193-203.

KIEFER, M,. MARTENS, U., WEISBROD, M., HERMLE, L., E SPITZER, M. (2009). Increased unconscious semantic activation in schizophrenia patients with formal thought disorder. Schizophrenia Research, 114, 79-83.

KIM, A. \& OSTERHOUT, L. The independence of combinatory semantic processing: evidence from event-related potentials. Journal of Memory and Language 52 (2005) 205-225.

KRAEPELIN E. Dementia Praecox and Paraphrenia (Barclay RM, Trans., Robertson GM, ed.). Huntington, NY: Krieger; 1919/1971. (Original work published 1909-1913; original translation of selected portions published 1919.)

KRIPKE, S. A. 1997. Speaker's Reference and semantic reference. In P. Ludlow. (Ed.) Readings in the philosophy of language. The MIT Press. 383-414. 
KUPERBERG, G.R. Building meaning in schizophrenia. Clin EEG Neurosci 2008;39: 99-102.

KUPERBERG, G.R. Language in schizophrenia. Part 1: an introduction. Lang Linguist Compass. (2010a);4:576-89.

KUPERBERG, G.R. (2010b) Language in Schizophrenia Part 2: What can psycholinguistics bring to the study of Schizophrenia... and vice versa? Lang Linguist Compass 4/8: 590-604.

KUPERBERG, G. R. \& CAPLAN, D. (2003) Language Dysfunction in Schizophrenia in: Schiffer, R.B., Rao, S.M., Fogel, B.S. (Eds.), Neuropsychiatry. Lippincott Williams and Wilkins, Philadelphia, pp. 444-466.

KUPERBERG, G.R., MCGUIRE, P.K. \& DAVID, S.D. Reduced sensitivity to linguistic context in schizophrenic thought disorder: evidence from on-line monitoring for words in linguistically anomalous sentences. Journal of Abnormal Psychology, 1998, Vol. 107, No. 3, 423-434.

KUPERBERG, G., SITNIKOVA, T. \& HOLCOMB, P.J. Making Sense of Sentences in Schizophrenia: Electrophysiological Evidence for Abnormal Interactions Between Semantic and Syntactic Processing. Journal of Abnormal Psychology by the American Psychological Association (2006), Vol. 115, No. 2, 251-265.

KUTTNER, R. E., LORINCZ, A. B., \& SWAN, D. A. 1967). The schizophrenia gene and social evolution. Psychological Reports, 20, 407 \pm 412 .

KWAPIL, THOMAS R., BARRANTES-VIDAL, N., \& SILVIA, PAUL J. The Dimensional Structure of the Wisconsin Schizotypy Scales: Factor Identification and Construct Validity Schizophrenia Bulletin vol. 34 no. 3 pp. 444-457, 2008 doi:10.1093/schbul/sbm098 Advance Access publication on September 3, 2007.

LANGDON R, COLTHEART M, WARD PB, CATTS SV. Disturbed communication in schizophrenia: The role of poor pragmatics and poor mind-reading. Psychol Med. 2002; 32:1273-1284.

LENNEBERG, E.H. (1967) Biological foundations of language. New York: Wiley.

LENZENWEGER, M.F. Schizotypy: an organizing framework for schizophrenia research. Curr Dir Psychol Sci. 2006;15:162-166.

LENZENWEGER, M.F. Thinking Clearly About Schizotypy: Hewing to the Schizophrenia Liability Core, Considering Interesting Tangents, and Avoiding Conceptual Quicksand. Schizophrenia Bulletin vol. 41 suppl. no. 2 pp. S483-S491, 2015 doi:10.1093/schbul/sbu184. 
LIDDLE, P.F., NGAN, E.T.C., CAISSIE, S.L., ANDERSON, C.M., BATES, A.T., QUESTED, D.J., WHITE, R., WEG, R., 2002. Thought and language index: an instrument for assessing thought and language in schizophrenia. Br. J. Psychiatry 181, 326-330.

LONGCHAMPS, J. R.; Corrêa, Letícia Maria Sicuro (Orientadora). Déficit Específico da Linguagem de ordem Pragmática (DEL-Prag) e dificuldades de aprendizagem: interface gramática- pragmática e relevância no uso da língua. Rio de Janeiro, (2014). 244p. Tese de Doutorado - Departamento de Letras, Pontifícia Universidade Católica do Rio de Janeiro.

LYONS, C. Definiteness. Cambridge University Press, 2004. (e-book).

MASON, J.O. The Assessment of Schizotypy and Its Clinical Relevance. Schizophrenia Bulletin vol. 41 suppl. No. 2 pp. S374-S385, 2015.

MARATSOS, M. P. The use of definite and indefinite reference in young children. Cambridge: Cambridge University Press, 1976.

MCCLEERY, A., DIVILBISS, M., ST-HILAIRE, A., AAKRE, J.M., SEGHERS, J.P., BELL, E.K. E DOCHERTY, N.M. Predicting Social Functioning in Schizotypy: An Investigation of the Relative Contributions of Theory of Mind and Mood, J Nerv Ment Dis. 2012 February; 200(2): 147-152.

MCKENNA, P. \& OH, T. Schizophrenic Speech: Making Sense of Bathroots and Ponds that Fall in Doorways. Cambridge, UK: Cambridge University Press; 2005.

MEEHL, P.E. Schizotaxia, Schizotypy, Schizophrenia. American Psychologist 17, 827838 (1962).

MEEHL, P.E. Toward an Integrated Theory of Schizotaxia, Schizotypy and Schizophrenia. Journal of Personality Disorders, 4, 1-99 (1990).

MENDES L, MAIA M, GOMES GC. Dislexia e processamento sintático. Rev. Psicopedagogia 2010;27(82):47-58.

MITCHELL, R.L.C. \& CROW, T.J. Right hemisphere language functions and schizophrenia: the forgotten hemisphere? Received January 3, 2005. Revised January 31, 2005. Accepted February 1, 2005. Advance Access publication. March 2, 2005 Brain (2005), 128, 963-978.

MORICE, R., \& MCNICOL, D. (1986). Language changes in schizophrenia. Schizophr. Bull. 12, 239-250. doi: 10.1093/schbul/12.2.239.

MÜLLER, A. 2002. The Semantics of Generic Quantification in Brazilian Portuguese. PROBUS, 14:279-298.

MUNN, A. \& SCHMITT, C. 2005. Number and indefinites. Lingua 115:821-855. 
MURDOCK, B. B. Jr. (1962). The serial position effect of free recall. Journal of Experimental Psychology, 64, 482-488.

NUNES, E. K. A construção de sentido de um enunciado pela Teoria da Relevância: uma abordagem do significado na interface semântico/pragmática. Revista Liberato, Novo Hamburgo, v.13, n. 20, p. 01-15, jul./dez. 2012.

OMS. Livro de recursos da OMS sobre saúde mental, direito humanos e legislação: cuidar, sim, excluir, não. Organização Mundial de Saúde, 2005.

OTT, S.L., ROBERTS, D., ROCK, J., ALLEN, L., E ERLENMEYER-KIMLING, L. (2002). Positive and negative thought disorder and psychopathology in childhood among subjects with adulthood schizophrenia. Schizophrenia Research, 2002, 231-239.

OWENS, D.G.C., MILLER, P., LAWRIE, S.M. e JOHNSTONE, E.C. Pathogenesis of schizophrenia: a psychopathological perspective. British Journal of Psychiatry (2005), $186,386-393$.

PELLETIER, F.J. 2001. Did Frege believe Frege's principle? Journal of Logic, Language, and Information 10:87-114.

PÉREZ-LEROUX, A. T.; MUNN, A.; SCHMITT, C.; DEIRISH, M. Learning definite determiners: genericity and definiteness in English and Spanish. In: Proceedings of the 28th Boston University Conference on Language Development. In: B. Beachley, A. Brown and F. Conlin (Eds.). Somerville, MA., Cascadilla Press, 2003.

PICKUP GJ, FRITH CD. Theory of mind impairments in schizophrenia: Symptomatology, severity and specificity. Psychol Med. (2001); 31:207-220.

PINKER, S. \& BLOOM, P. Natural language and natural selection. Behavioral and Brain Sciences, v. 13, n. 4, p. 707-784, 1990.

POWER, C. 2009 Sexual selection models for the emergence of symbolic communication: why they should be reversed. In Botha, R. \& Knight, C. (Eds.) The Cradle of Language Studies in the evolution of language. 257-280. Oxford, Oxford University Press.

QUINE, W. V. O. Word and object. Cambridge, MA: MIT, 1960.

RABALlO, A. \& PARNAS, J. The Silent Side of the Spectrum: Schizotypy and the Schizotaxic Self. Schizophrenia Bulletin vol. 37 no. 5 pp. 1017-1026, 2011 doi:10.1093/schbul/sbq008 Advance Access publication on February 22, 2010.

RAINE, A. The SPQ: A scale for the assessment of schizotypal personality based on DSM-III-R criteria. Schizophrenia Bulletin, 17(4): 555-564, 1991. 
RAINE, A., REYNOLDS, C. LENCZ, T., SCERBO, A., TRIPHON, N., and KIM, D. Cognitive perceptual, interpersonal, and disorganized features of schizotypal personality. Schizophrenia Bulletin, 20(1):191-202, 1994.

RADANOVIC, M., SOUSA, R.T., VALIENGO, L.L., GATTAZ, W.F., FORLENZA, O.V. Alteração formal do pensamento e prejuízo da linguagem na esquizofrenia. Arq. Neuro-Psiquiatr. [online] (2013), vol.71, n.1, pp. 55-60.

RADO, S. (1960). Theory and therapy: the theory of schizotypal organization and its application to the treatment of decompensated schizotypal behavior. In: Scher SC, Davis HR, eds. The Outpatient Treatment of Schizophrenia. New York, NY: Grune and Stratton; 1960:87-101.

ROBERTS, C. 2003. Uniqueness in definite noun phrases. Linguistics and Philosophy 26:287350.

ROCHESTER, SR. Are language disorders in acute schizophrenia actually informationprocessing problems? In: Wynne LC, Cromwell RL, Matthysse S, editors. The nature of schizophrenia, new approaches to research and treatment. New York, NY: John Wiley; 1978. p. 320-8.

ROCHESTER, SR. \& MARTIN, JR. Crazy talk: a study of the discourse of schizophrenic speakers. New York, NY: Plenum; 1979.

RODRIGUES, C \& DAL POZZO, L. Pronominal possessives in Pro-drop languages: an experimental study. In: V CIEL: Workshop em linguística formal. 2015. Universidade de Brasília, UnB (2016), p.26-30. Disponível em http://www.lefog.pro.br/wpcontent/uploads/2016/08/V_CIEL_FinalBooklet.pdf.

ROMNEY DM (1990). Thought disorder in the relatives of schizophrenics. A metaanalytic review of selected published studies. The Journal of Nervous and Mental Disease, 178, 481-486.

RUSSELL, B. On Denoting. Mind, New Series, Vol. 14, No. 56. (Oct. 1905), pp. 479493.

RUSSELL, B. 1919. Introduction to Mathematical Philosophy. London: Allen and Unwin.

SARFATI Y, HARDY-BAYLE MC, BRUNET E, WIDLOCHER D. Investigating theory of mind in schizophrenia: influence of verbalization in disorganized and nondisorganized patients. Schizophr Res. (1999); 37:183-190.

SCHNEIDER K. Primary and secondary symptoms of schizophrenia (1957). In: Shepperd SHM, editor. Themes and variations on european psychiatry. Bristol: John 
Wright \& Sons Ltd; 1974. p. 40-4.

SIEVER, L.J. \& DAVIS, K.L. The pathophysiology of schizophrenia disorders: perspectives from the spectrum. Am J Psychiatry. 2004;161(3):398-413.

SHENTON, M.E., DICKEY, C.C., FRUMIN, M. E MCCARLEY, R.W. A review of MRI findings in schizophrenia NIH Public Access Author Manuscript Schizophr Res. Author manuscript; available in PMC 2010 January 27. Published in final edited form as: Schizophr Res. 2001 April 15; 49(1-2): 1-52.

SOLOWAY, M.R., HOLZMAN, P.S., COLEMAN, M., GALE, H.J. E SHENTON, M.E. (1989). Thought disorder in the relatives of psychotic patients. Archives of General Psychiatry, 46, 897-901.

SPITZER, M. A cognitive neuroscience view of schizophrenic thought disorder. Schizophr Bull. 1997;23:29-50.

SPITZER, M., BRAUN, U., HERMLE, L., E MAIER, S. (1993). Associative semantic network dysfunction in thought-disordered schizophrenic patients: direct evidence from indirect semantic priming. Biol. Psychiatry, 34, 864-877.

STALnAKeR, R. Pragmatic and Presupposition. In Context and Content. Oxford University Press. Pp. 47-62 (1974).

STEEL, C., HEMLEY, D.R., e PICKERING, A.D. Associations between schizotypal personality traits and the facilitation and inhibition of the speed of contextually cued responses. Psychiatry Res. 2007;150:131-40. Epub 2007 Feb 6.

STRAWSON, P.F. On Refering Mind, New Series, VOl.59, No.235. (Jul., 1950), pp. 320-344.

THOMAS, M. The acquisition of language articles by first-and second-language learners. Applied Psycholinguistics. Vol. 10, Issue 3. September 1989, pp. 335-355.

THORNTON, R. \& WEXLER, K. (1999) Principle B, VP ellipsis, and interpretation in child grammar. Cambridge, MA: MIT Press.

TOGA, A. \& THOMPSON, P. Mapping brain asymmetry, Nature Reviews, Neuroscience vol. 4, jan. 2003 Nature Publishing Group.

TONELLI, HA. How semantic deficits in schizotypy help understand language and thought disorders in schizophrenia: a systematic and integrative review. Trends Psychiatry Psychother. 2014;36(2):75-88.

TONELLI, H., ALVAREZ, C. E. \& SILVA, A.A. Esquizotipia, habilidades "Teoria da Mente" e vulnerabilidade à psicose: uma revisão sistemática. Revista de Psiquiatria 
Clínica. 2009;36(6):229-39.

TONELLI, H., VON DER HEYDE, M.D., ALVAREZ, C. E. \& RAINE, A. Versão em português do Questionário da Personalidade Esquizotípica - SPQ. Revista de Psiquiatria Clínica. 2009;36(1):34-37.

VALLADA, HE., SAMAIA, H. Esquizofrenia: aspectos genéticos e estudos de fatores de risco. Revista Brasileira de Psiquiatria, 2000;22(Supl I):2-4.

VOLLEMA, M.Q. \& HOIJTINK, H. The Multidimensionality of Self-Report Schizotypy in a Psychiatric Population: An Analysis Using Multidimensional Rasch Models, Schizophrenia Bulletin, Vol. 26, No. 3, 2000.

VON HEUSINGER, K. Specificity and definiteness in sentence and discourse structure. Journal of Semantics 19, p. 245-274, 2002.

WATSON, A.R., DEFTERALI, Ç., BAK, T.H., SORACE, A., MCINTOSH, A.M., OWENS, D.G.C., JOHNSTONE, E.C., E LAWRIE, S.M. 2012. Use of second person pronouns and schizophrenia. British Journal of Psychiatry 200: 342-3.

WHO. The World health report, 2001 : Mental health : new understanding, new hope.

WILSON, D; SPERBER, D. Teoria da relevância. Linguagem em (Dis)curso, [S.1.], v. 5 , p. 221-268, set. 2010. ISSN 1982-4017. Disponível em: $<\mathrm{http} / / /$ www.portaldeperiodicos.unisul.br/index.php/Linguagem_Discurso/article/view/2 87>. Acesso em: 16 abril 2017.

WING, J. K., COOPER, J. E., \& SARTORIUS, N. (1974). Present state examination. London: Medical Research Council.

WITTGENSTEIN, L. (2001) [1953]. Philosophical Investigations. Blackwell Publishing. ISBN 0-631-23127-7

ZIMMERER, V.C., WATSON, S., TURKINGTON, D., FERRIER, N. \& HINZE, W. Deictic and propositional meaning - new perspectives on language in schizophrenia. Frontiers in Psychiatry. Feb 2017, vol. 8, Art. 17. 


\section{Apêndice 1: Teste de linguagem}

Relação de itens por condição:

- Itens da condição 1: indefinida específico com reforço de contexto

i. O João comprou uma vassoura de piaçava importada. Ele estava no mercado ontem. Ele me disse que a vassoura é indiana.

- O que é indiana?

a. Qualquer vassoura

b. Nenhuma vassoura

c. A vassoura de piaçava importada que o João comprou

ii. A Aninha ganhou um vestido de seda pura. Ela estava no Rio de Janeiro no sábado. Ela me falou que o vestido fica bem em ocasiões formais.

- O que fica bem em ocasiões formais?

a. Qualquer vestido

b. Nenhum vestido

c. O vestido de seda pura que a Aninha ganhou

iii. Minha amiga comeu um bombom de chocolate belga. Ela teve uma reação alérgica. Ela comentou que o bombom leva açúcar demais.

- O que leva açúcar demais?
a. Qualquer bombom
b. Nenhuma bombom
c. O bombom de chocolate belga que minha amiga comeu

iv. Meu pai comprou uma boina de lã xadrez. Ele estava gripado na semana passada. Ele me contou que a boina é francesa.

- O que é francesa?

a. Qualquer boina

b. Nenhuma boina

c. A boina de lã xadrez que o meu pai comprou

v. Meu arquiteto projetou uma cadeira de couro vegetal. Ele ganhou um prémio no ano passado. Ele disse que a cadeira define o ambiente do escritório.

- O que define o ambiente do escritório?
a. Qualquer cadeira
b. Nenhuma cadeira
c. A cadeira de couro vegetal que o meu arquiteto projetou

- Itens da condição 2: indefinida específico sem reforço de contexto

i. Minha cunhada comprou um cachorro de raça grande. Ela me contou que o cachorro sabe pelo cheiro se uma pessoa está doente.

- Quem sabe pelo cheiro se uma pessoa está doente?
a. Qualquer cachorro
b. Nenhum cachorro
c. O cachorro de raça grande que a minha cunhada comprou 
ii. A Mariana ganhou um boneco de pano molenga. Ela falou que o boneco é ótimo de brincar.

- O que é ótimo de brincar?
a. Qualquer boneco
b. Nenhum boneco
c. O boneco de pano molenga que a Mariana ganhou

iii. Meu psicólogo tratou de uma criança da baixada fluminense. Ele me disse que a criança é muito sensível à violência social.

- Quem é sensível à violência social?
a. Qualquer criança
b. Nenhuma criança
c. A criança da baixada fluminense que meu psicólogo tratou

iv. O Pedro achou uma bola de couro usada. Ele me falou que a bola é ótima para jogar altinha na praia.

- O que é ótima para jogar altinha na praia?
a. Qualquer bola
b. Nenhuma bola
c. A bola de couro usada que o Pedro achou

v. Minha médica atendeu um idoso de personalidade complicada. Ela comentou que o idoso tem dificuldade até para marcar consultas.

- Quem tem dificuldade até para marcar consulta?
a. Qualquer idoso
b. Nenhum idoso
c. O idoso de personalidade complicada que minha médica atendeu

- Itens da condição 3: singular nu com reforço de contexto

i. O Luís estudou baleia no mestrado. Ele fez a faculdade no Canadá. Ele me contou que a baleia dorme na vertical.

- Quem dorme na vertical?
a. Qualquer baleia
b. Nenhuma baleia
c. A baleia que o Luís estudou no Canadá

ii. A nossa professora escreveu romance na juventude. Ela recebeu um premio na FLIP. Ela nos disse que o romance é difícil de escrever.

- O que é difícil de escrever?
a. Qualquer romance
b. Nenhum romance
c. O romance que a nossa professora escreveu na juventude

iii. O meu primo criou abelha na infância. Ele viveu um sítio em Minas. Ele me falou que a abelha é muito pouco estudada.

- Quem é muito pouco estudada?

a. Qualquer abelha 
b. Nenhuma abelha

c. A abelha que o meu primo criou na infância

iv. A minha avó plantou feijão na fazenda. Ela estudou agricultura na Rural. Ela comentou que o feijão é próprio para o clima do Brasil.

- O que é próprio para o clima do Brasil?
a. Qualquer feijão
b. Nenhum feijão
c. O feijão que minha avó plantou na fazenda

v. A Carla confeccionou biquíni nos anos 80. Ela aprendeu modelagem em Paris. Ela comentou que o biquíni é perfeito para o corpo da carioca.

- O que é perfeito para o corpo da carioca?
a. Qualquer biquíni
b. Nenhum biquíni
c. O biquíni que a Carla confeccionou

- Itens da condição 4: singular nu sem reforço de contexto

i. O Fernando criou galinha no sítio. Ele me falou que a galinha cisca o dia inteiro.

- Quem cisca o dia inteiro?
a. Qualquer galinha
b. Nenhuma galinha
c. A galinha que o Fernando criou no sítio

ii. A minha tia colecionou bule quando jovem. Ela comentou que o bule é ideal para fazer chá.

- O que é ideal para fazer chá?
a. Qualquer bule
b. Nenhum bule
c. O bule que a minha tia avó colecionou quando jovem

iii. O meu porteiro consertou bicicleta na adolescência. Ele me disse que a bicicleta é fácil de consertar.

- O que é fácil de consertar?
a. Qualquer bicicleta
b. Nenhuma bicicleta
c. A bicicleta que o meu porteiro consertou na adolescência

iv. O Fernando vendeu faca na juventude. Ele me contou que a faca é da Ásia. - O que é da Ásia?
a. Qualquer faca
b. Nenhuma faca
c. A faca que o Fernando vendeu na juventude

v. A Dona Maria fez pão a vida inteira. Ela falou que o pão leva muito fermento. - O que leva muito fermento?
a. Qualquer pão 
b. Nenhum pão

c. O pão que a Dona Maria fez a vida inteira

\section{Relação de itens distratores}

- Distratrores tipo 1

Ontem, entrou um cachorro no hospital. O médico disse que a enfermeira viu o homem pegar o cachorro e a mulher também.

- O que aconteceu com a mulher?

a. Viu o homem pegar o cachorro

b. Não aconteceu nada

c. Também disse que a enfermeira viu o homem pegar o cachorro

Hoje, apareceu um gato na escola. O professor contou que a coordenadora viu uma aluna levar o gato e o guarda também.

- O que aconteceu com o guarda?
a. Viu uma aluna levar o gato
b. Não aconteceu nada
c. Também contou que a coordenadora viu uma aluna levar o gato

Ontem, teve um roubo no aviário perto da obra. $\mathrm{O}$ engenheiro declarou que o pedreiro viu o mendigo roubar um frango e a velha também.

- O que aconteceu com a velha?

a. Viu o mendigo roubar um frango

b. Não aconteceu nada

c. Também falou que o pedreiro viu o mendigo roubar um frango

Ontem, tinha muita gente na sala de emergência. A enfermeira comentou que o bombeiro viu o médico atender o paciente e o índio também.

- O que aconteceu com o índio?

a. Viu o médico atender o paciente

b. Não aconteceu nada

c. Também comentou que o bombeiro viu o médico atender o paciente

De madrugada, teve gente que lavou o carro. O porteiro falou que a síndica viu o motorista lavar o carro e vigia também.

- $\mathrm{O}$ que aconteceu com o vigia?

a. Viu o motorista lavar o carro

b. Não aconteceu nada

c. Também falou que a síndica viu o motorista lavar o carro

Ontem, aconteceu de tudo na praia. O salva-vidas disse que o turista viu o surfista agarrar a modelo e a atriz também.

- O que aconteceu com a atriz?

a. Viu o surfista agarrar a modelo

b. Não aconteceu nada

c. Também disse que o turista viu o surfista agarrar a modelo 
Hoje de manhã, foi o maior bafafá na frente do meu prédio. O repórter declarou que o engenheiro viu o policial derrubar uma criança e a mulher também.

- O que aconteceu com a mulher?

a. Viu o policial derrubar uma criança

b. Não aconteceu nada

c. Também declarou que o engenheiro viu o policial derrubar uma criança

Outro dia, entrou um bichano na clínica. A enfermeira falou que o homem viu o médico chutar o bichano e a recepcionista também.

- O que aconteceu com a recepcionista?

a. Viu o médico chutar o bichano

b. Não aconteceu nada

c. Também falou que o homem viu o médico chutar o bichano

Ontem, teve uma reunião da escola. A coordenadora contou que a secretária viu o professor beliscar uma menina e o secretário também.

- O que aconteceu com o secretário?

a. Viu o professor beliscar uma menina

b. Não aconteceu nada

c. Também contou que a aluna viu o professor beliscar uma menina

Esta semana, teve uma explosão na obra. O bombeiro comentou que o engenheiro viu o pedreiro chamar o operário e o mestre de obras também.

- O que aconteceu com o mestre de obras?

a. Viu o pedreiro chamar o operário

b. Não aconteceu nada

c. Também comentou que o engenheiro viu o pedreiro chamar o operário

- Distratores tipo 2

O Carlinhos é muito mal educado. Ele vive mexendo nas coisas dos outros. Ontem, o Carlinhos foi brincar com faca do Fernando e cortou o dedo dele.

- De quem é o dedo que foi cortado?
a. Do Carlinhos
b. Do Fernando
c. De ninguém

O Paulão sabe tudo de bicicleta. Ele sempre testa a bicicleta dos amigos. Ontem, ele estava testando a bicicleta do Carlos e quebrou a perna dele.

- De quem é a perna que foi quebrada?
a. Do Paulão
b. Do Carlos
c. De ninguém

O João e o Pedrinho são melhores amigos. Os dois vivem aprontando um com o outro. Da última vez que estive com eles, o João estava brincando com o canivete do Pedrinho e cortou a mão dele.

- De quem é a mão que foi cortada?
a. Do João 

b. Do Pedrinho
c. De ninguém

O Fernando e o Diogo são amigos de infância. Eles aprenderam a surfar juntos. Quando foram ao Peru, o Fernando estava usando a prancha de surf do Diogo e quebrou o braço dele.

- De quem é o braço que foi quebrado?
a. Do Fernando
b. Do Diogo
c. De ninguém

O Ângelo e o Felipe jogam muita bola. Eles são os craques do time da escola. Ontem no recreio, o Ângelo estava brincado com a bola do Felipe e fraturou o pé dele.

- De quem é o dedão que foi fraturado?
a. Do Ângelo
b. Do Felipe
c. De ninguém

A Laura e a Maria são muito amigas. Elas vivem na casa uma da outra. O outro dia, a Laura estava mexendo na tesoura da Maria e cortou o cabelo dela.

- De quem é o cabelo que foi penteado?
a. Da Laura
b. Da Maria
c. De ninguém

A Joana e a Fernanda são irmãs. Elas adoram mexer nas coisas uma da outra. Hoje, a Joana estava brincando com o estojo de maquiagem da Fernanda e pintou os olhos dela.

- De quem são o olhos que foram pintados?
a. Da Fernanda
b. Da Joana
c. De ninguém

A Cristina é cabelereira. Ela cuida do cabelo de todas as amigas. Mês passado, ela estava mexendo nas tintas da Paula e pintou o cabelo dela.

- De quem é o cabelo que foi pintado?
a. Da Cristina
b. Da Paula
c. De ninguém

A Patrícia é ótima enfermeira. Ela também adora costurar. Outro dia, ela estava mexendo com os alfinetes da Maria e furou o dedo dela.

- De quem é a orelha que foi furada?
a. Da Patrícia
b. Da Maria
c. De ninguém

A Aninha e a Daniela têm uma festa. Elas resolveram se arrumar na casa da Daniela. A Aninha estava testando a maquiagem da Daniela e maquiou o rosto dela. 
- De quem é o rosto que foi maquiado?
a. Da Aninha
b. Da Daniela
c. De ninguém

A Catarina é muito curiosa. Ela vai ao consultório do Dr. Carlos e mexe em tudo. Outro dia, ela estava brincado com a agulha do Dr. Carlos e furou a mão.

- De quem é o cabelo que foi cortado?
a. Da Catarina
b. Do Hélio
c. De ninguém

Meu primo é muito estabanado. Ele sempre mexe em tudo. Ontem, ele estava brincando com uma pinça da minha mãe e perfurou o tímpano.

- De quem é o tímpano que foi perfurado?
a. Do meu primo
b. Da minha mãe
c. De ninguém

A Maria tem mania de esmalte. Ela vive comprando esmaltes novos. Outro dia, ela estava mexendo nos esmaltes da Ana e pintou a unha.

- De quem é a unha que foi pintada?
a. Da Maria
b. Da Ana
c. De ninguém

Minha prima namora o Marcelo. Ele adora andar de skate. Outro dia, ela estava usando o skate do Marcelo e ralou o cotovelo.

- De quem é o cotovelo que foi ralado?
a. Da minha prima
b. Do Marcelo
c. De ninguém

A Denise é arquiteta. Ela desenha muito bem. Outro dia, ela usou as canetas do Mário e riscou a mão.

- De quem é a mão que foi riscada?
a. Da Denise
b. Do Mário
c. De ninguém

A Sara é decoradora. Ela adora tarefas manuais. Certo dia, ela estava mexendo com os pregos do Edu e furou o dedo.

- De quem é o dedo que foi furado?
a. Da Sara
b. Do Edu
c. De ninguém

O João é ótimo pai. Ele cuida muito bem do filho. No domingo, ele pegou a mamadeira do menino e queimou a mão.

- De quem é a mão que foi queimada? 

a. Do João
b. Do menino
c. De ninguém

A Teresa é ótima cozinheira. Ela entende tudo de cozinha. No jantar, ela estava mexendo na faca da Lúcia e cortou o dedo.

- De quem é o dedo que foi cortado?
a. Da Teresa
b. Da Lúcia
c. De ninguém

O cachorro do Pedro é muito agitado. Ele sempre briga com o gato. Outro dia, ele estava fuçando na comida do gato e machucou o focinho.

- De quem é a pata que foi machucada?
a. Do cachorro
b. Do gato
c. De ninguém

O Flavinho e o Maurício são ótimos alunos. Eles sempre estudam juntos. Outro dia, o Flavinho estava brincando com o clip do Maurício e machucou o olho.

- De quem é o dedo que foi furado?
a. Do Flavinho
b. Do Maurício
c. De ninguém

Itens de treino

A Beatriz é professora de inglês. Ontem, ela deu todas as aulas da parte da manhã. Foram 15 no total. Ela ficou muito cansada.

- Quantas aulas a Beatriz deu ontem?
a. Nenhum aula
b. 10 aulas
c. 15 aulas

O Gonçalo é ótimo mecânico. Ele conserta de tudo. Outro dia, o Gonçalo estava usando o alicate do Miguel e machucou o dedo.

- De quem é o dedo que foi machucado?
a. Do Gonçalo
b. Do Miguel
c. De ninguém

Ontem, teve uma discussão no meu prédio. A síndica disse que o porteiro viu o vizinho xingar a faxineira e o garagista também.

- O que aconteceu com o garagista?
a. Viu o vizinho xingar a faxineira
b. Não aconteceu nada
c. Também disse que o porteiro viu o vizinho xingar a faxineira 


\section{Apêndice 2: Escalas escalas psicométricas de auto-avaliação}

SPQ - Schizotypical Personality Questionaire (Raine, 1991; Raine et al., 1994)

- SPQ - 9 dimensões: ideias de referência, pensamento mágico, experiências perceptuais incomuns, ideação paranoide, ansiedade social, falta de amigos íntimos, afeto constrito, fala bizarra e comportamento bizarro.

- SPQ - 3 dimensões: dimensão 1(cognitiva-perceptual), dimensão 2 (interpessoal) e dimensão 3 (desorganização).

Relação dos itens de cada uma 9 dimensões, mas com indicações a respeito de sua localização na organização em 3 dimensões:

A. Ideias de referência: (dimensão 1)

1. Às vezes você sente que coisas a que assiste na TV ou lê nos jornais têm um significado especial para você?

10. Tenho consciência de que as pessoas me notam quando saio para comer ou para ver um filme.

19. Algumas pessoas parecem lhe sinalizar algo ou dizer coisas com duplo sentido?

28. Você já achou que um evento corriqueiro ou um objeto comum pudessem ser um sinal especial para você?

37. Você às vezes vê significados especiais em propagandas, vitrines ou nas coisas ao seu redor?

45. Ao fazer compras, você sente que as outras pessoas estão lhe notando?

53. Quando você vê pessoas conversando, você frequentemente pensa que podem estar falando a seu respeito?

60. Às vezes você acha que outras pessoas estão lhe observando?

63. Às vezes você acha que as pessoas estão falando sobre você?

B. Pensamento mágico: (dimensão 1)

3. Você teve experiências sobrenaturais?

12. Você acredita em telepatia (leitura da mente)?

21. Às vezes você tem certeza de que outras pessoas podem dizer o que você está 
pensando?

30. Você acredita em clarividência (forças psíquicas, predição do futuro)?

39. Pessoas podem sentir os seus sentimentos quando elas não estão por perto?

47. Você teve experiências com astrologia, previsão do futuro, OVNIs (objetos voadores não identificados ou discos voadores), percepção extra-sensorial ou sexto sentido?

55. Você já pensou que estava se comunicando telepaticamente (por meio de leitura de pensamentos) com outra pessoa?

C. Experiências perceptuais incomuns: (dimensão 1)

4. Você frequentemente interpreta objetos ou sombras como pessoas, ou sons como vozes?

13. Você já teve a sensação de que alguma pessoa ou uma força está ao seu redor, embora você não veja ninguém?

22. Ao olhar para uma pessoa, ou a você mesmo em um espelho, você já viu a face mudando de aspecto diante dos seus olhos?

31. Frequentemente ouço uma voz falando meus pensamentos.

40. Você já viu coisas que são invisíveis para outras pessoas?

48. Coisas do dia-a-dia parecem incomumente grandes ou pequenas para você?

56. Às vezes seu olfato se torna incomumente estranho?

61. Você já se sentiu repentinamente distraído por sons distantes dos quais você não está habitualmente consciente?

64. Às vezes seus pensamentos são tão intensos que você quase pode ouvi-los?

D. Ideação paranoide: (dimensão 1 e dimensão 2)

9. Estou certo de que falam de mim pelas costas.

18. Você frequentemente sente que as pessoas se aproveitaram de você?

27. Às vezes você se preocupa que amigos ou colegas de trabalho não são realmente leais ou confiáveis?

36. Sinto que devo estar na defensiva até mesmo com meus amigos.

44. Você frequentemente sente ameaças ou humilhações disfarçadas no discurso ou na atitude das pessoas?

52. Você já pensou que é melhor não deixar as pessoas saberem muito a seu respeito?

59. Frequentemente acho que os outros estão ressentidos comigo. 
65. Você frequentemente tem que tomar cuidado para evitar que as pessoas tirem vantagem de você?

E. Ansiedade social: (dimensão 2)

2. Às vezes eu evito ir a lugares onde haverá muitas pessoas porque ficarei ansioso.

11. Fico muito nervoso quando tenho que ter uma conversa formal.

20. Você fica nervoso quando alguém está andando atrás de você?

29. Fico ansioso ao encontrar pessoas pela primeira vez.

38. Você se sente frequentemente nervoso quando está em um grupo de pessoas desconhecidas?

46. Sinto-me desconfortável em situações sociais que envolvem pessoas desconhecidas.

54. Eu iria me sentir muito ansioso se tivesse que falar em frente a um grupo grande de pessoas.

71. Sinto dificuldade em ter que falar com pessoas que não conheço bem.

F. Falta de amigos íntimos: (dimensão 2)

6. Tenho pouco interesse em conhecer outras pessoas.

15. Prefiro ficar sozinho.

24. Na maior parte das vezes, fico quieto diante de outras pessoas.

33. Acho difícil me aproximar emocionalmente de outras pessoas

41. Você sente que não há alguém de quem você se sinta próximo fora de sua família?

49. Escrever cartas para amigos dá mais trabalho do que vale a pena.

57. Tendo a ficar meio escondido em situações sociais.

62. Dou pouca importância a ter amigos próximos.

66. Você se sente incapaz de se aproximar de pessoas?

G. Afeto constrito: (dimensão 2)

8. As pessoas às vezes me acham reservado e distante.

17. Tenho dificuldade em expressar meus sentimentos verdadeiros por meio de minha fala e de meu olhar.

26. Raramente dou gargalhadas ou sorrio.

35. Minha comunicação "não-verbal” (sorrir e balançar a cabeça, por exemplo) é pobre. 
43. Tenho dificuldade em responder a cortesias e gestos sociais.

51. Tendo a evitar olhar nos olhos das pessoas com quem converso.

68. Não tenho um jeito expressivo e animado de falar.

73. Tendo a guardar meus sentimentos para mim mesmo.

H. Fala bizarra: (dimensão 3)

7. As pessoas às vezes acham difícil entender o que estou falando.

16. Às vezes passo de um assunto para outro rapidamente enquanto falo.

25. Às vezes, esqueço o que estou tentando dizer.

34. Frequentemente me confundo muito ao falar.

42. Algumas pessoas acham que sou um pouco vago e evasivo durante uma conversa.

50. Às vezes, emprego palavras de um jeito incomum

58. Você tende a perder o "fio da meada" durante uma conversa?

69. Acho difícil comunicar claramente o que quero às pessoas.

72. As pessoas ocasionalmente comentam que minha conversa é confusa.

I. Comportamento bizarro: (dimensão 3)

5. Outras pessoas me veem como particularmente excêntrico (esquisito).

14. As pessoas algumas vezes comentam sobre meus trejeitos ou hábitos incomuns.

23. Às vezes, outras pessoas pensam que eu sou um pouco estranho.

32. Algumas pessoas acham que sou uma pessoa muito estranha.

67. Sou uma pessoa estranha e incomum.

70. Tenho alguns hábitos excêntricos (estranhos).

74. As pessoas às vezes ficam me observando por causa de minha aparência estranha.

FTD-S - Formal Thought Disorder-Self (Barrera et al., 2015)

FTD-S 3 dimensões

A) Dimensão 1: fala bizarra (15 itens)

7. Eu sussurro ou murmuro baixinho sem nenhuma razão específica.

12. Quando falo, me vem a mente mais palavras do que o necessário para expressar algo. 
13. Falo tão rápido (ou tão devagar) que outras pessoas acham isso bobo ou inapropriado.

14. Gosto de inventar palavras que só têm sentido para mim.

15. Já me peguei falando de um jeito que outras pessoas podem achar estranho.

16. Me pego tirando conclusões estranhas durante conversas.

17. Uso palavras longas, sofisticadas e pouco comuns para dizer coisas simples.

18. Já me peguei repetindo sem querer coisas que outras pessoas me disseram.

19. Gosto de repetir palavras que outras pessoas acabaram de me dizer.

22. Levo um tempo excessivamente longo para responder perguntas.

23. Tendo a usar muitas palavras para dizer coisas simples.

24. Reparo que, em conversas, tenho a tendência a ficar dando voltas.

25. Não sei como perguntar às pessoas para explicarem o que elas querem dizer.

27. Me pego falando sem intenção de falar.

28. Fico enrolando e evito ir direto ao ponto da conversa.

B) Dimensão 2: habilidade para conversas (7 itens)

4. Durante uma conversa, nem sempre estou completamente focado nela.

8. Tendo a ficar sem palavras durante conversas.

9. Acho difícil iniciar uma conversa.

10. É um esforço para mim falar por muito tempo.

11. Quanto mais pessoas estão conversando, mais perdido eu fico.

20. Falar me deixa psicologicamente exausto.

26. Acho difícil colocar em palavras o que quero dizer.

C) Dimensão 3: déficit de memória de trabalho (7 itens)

1. Perco a noção do que acabei de dizer em uma conversa.

2. Tendo a esquecer aquilo que queria dizer em uma conversa.

3. Quando estou falando, minha mente de repente dá branco.

5. Esqueço o que outras pessoas acabaram de dizer durante conversas.

6. Minha fala fica bloqueada de repente e não consigo colocar as palavras para fora.

21. Tenho apenas fragmentos de memória daquilo que foi dito durante uma conversa.

29. Acho difícil dar instruções, tais como informações sobre como chegar a um lugar. 


\section{Apêndice 3: Questionário social e linguístico}

Perguntas complementares

Nome:

Sexo (assinalar um): Masculino ( ) Feminino ( )

Escolaridade (assinalar um): Ensino médio incompleto ( )

Ensino médio completo ( )

Superior incompleto ( )

Superior completo ( )

Caso tenha curso superior - completo ou não - favor informar a universidade e o curso:

Local de nascimento:

Data de nascimento (DD/MM/AA):

e-mail:

Você é (assinalar um): $\quad$ destro $(\quad$ canhoto $(）$ ambidestro $(\quad$ )

Alguém em sua família (parentes próximos) já foi diagnosticado com algum tipo de desordem psicológica, como por exemplo, depressão, ansiedade, transtorno de personalidade, mania, esquizofrenia etc.?

Em caso positivo, por favor, informe a desordem e o grau de parentesco entre vocês.

Alguém em sua família (parentes próximos) já foi diagnosticado com algum tipo de desordem de linguagem, como por exemplo, dislexia e DEL?

Em caso positivo, por favor, informe a desordem e o grau de parentesco entre vocês.

Você fala algum idioma além do português?

Em caso positivo, por favor, informe qual idioma(s), quando aprendeu e nível de fluência. 
Anexo 4

\section{TERMO DE CONSENTIMENTO LIVRE E ESCLARECIDO}

Você está sendo convidado(a) como voluntário(a) a participar de uma pesquisa em linguagem e cognição. A pesquisa tem como responsável a mestranda Monica de Freitas Frias Chaves, RG 05952136-9, CPF 823.319.527-87, sob a orientação da Profa. Dra. Cilene Rodrigues, RG 1381029/SSPDF, CPF 611.478.771-49, especialista em linguística teórica, professora do Programa de Pós-graduação em Estudos da Linguagem da PUC-Rio e Prof. Dr. Daniel Mograbi, RG 12567414-3, CPF 087.003.147-30, especialista em Neuropsicologia, professor do Programa de Pós-graduação em Psicologia Clínica da PUC-Rio.

Nesta pesquisa, pretendemos investigar se a variável perfil psicológico poderia influenciar a interpretação/compreensão do falante adulto do português brasileiro no que tange a interpretação de estruturas linguísticas. Nosso objetivo é verificar se há um padrão de interpretação/compreensão de enunciados no que diz respeito à referencialidade linguística e como esse padrão se manifesta em indivíduos com diferentes traços de personalidade. Para este fim, os participantes deverão responder dois questionários de auto-avaliação que nos permitirá agrupá-los de acordo com diferentes perfis psicológicos e também um questionário linguístico, que nós mostrará preferências de leituras para determinadas estruturas gramaticais.

Assim, para esta pesquisa, iremos adotar os seguintes procedimentos: você irá responder 3 questionários, sendo 2 de auto-avaliação de perfil psicológico e 1 de compreensão linguística. A atividade não tem nenhum caráter de avaliação do desempenho e/ou de conhecimento da língua, e sua duração deve ser em torno de 50 minutos. Os riscos envolvidos na pesquisa consistem em "RISCOS MÍNIMOS", isto é, o mesmo risco existente em atividades rotineiras como conversar, ler um livro, ouvir uma música, assistir à televisão etc. A pesquisa contribuirá para o entendimento de como se organiza a cognição de indivíduos com diferentes perfis psicológicos quanto a linguagem.

Você não terá qualquer custo para participar desse estudo e também não haverá vantagens financeiras. Sua participação não lhe trará benefícios diretos; todavia, as informações obtidas serão de extrema relevância para a compreensão de como se organiza a cognição e a linguagem humana. Você pode solicitar o esclarecimento sobre o estudo acerca dos aspectos que desejar e pode retirar seu consentimento ou interromper sua participação a qualquer momento. A sua participação é voluntária e sua recusa em participar não acarretará penalidades de nenhuma ordem; também não haverá qualquer tipo de mudança relativa à forma como é tratado(a) e atendido(a) pelo pesquisador. Não há riscos físicos ou morais previstos. Todas as informações têm caráter confidencial, sendo a apresentação de resultados realizada através de codinomes ou nomes inventados, de modo a impedir a identificação individual de cada participante. Você fornecerá nome, endereço, telefone e e-mail de contato apenas para que a equipe do estudo possa lhe contactar em caso de necessidade. Seu nome ou material que indique sua participação não serão em hipótese alguma liberados sem sua permissão. Os resultados da pesquisa estarão à sua disposição quando esta for concluída.

Este termo de consentimento encontra-se impresso em duas vias originais, sendo que uma será arquivada pelo pesquisador responsável e a outra via será fornecida a você. Os pesquisadores 
tratarão a sua identidade com padrões profissionais de sigilo, atendendo à legislação No 466/12 do Conselho Nacional de Saúde), utilizando as informações somente para fins acadêmicos e científicos.

$\mathrm{Eu}$, portador(a) do documento de identidade de maneira livre, esclarecida e voluntária, concordo em participar da pesquisa em linguagem e cognição acima explicitada. Estou ciente do assunto, do objetivo do estudo, dos procedimentos, das garantias de confidencialidade e da possibilidade de esclarecimentos permanentes sobre os mesmo. Está claro que minha participação é isenta de despesas e que minha imagem e meu nome não serão publicados sem minha prévia autorização por escrito. Estou ciente de que, em qualquer fase da pesquisa, tenho a liberdade de recusar a minha participação ou retirar meu consentimento, sem penalização alguma e sem nenhum prejuízo, e declaro que recebi uma via original deste termo de consentimento livre e esclarecido, tendo sido me dada a oportunidade de ler e esclarecer as minhas dúvidas. Declaro ainda que, em caso de qualquer questão relativa aos aspectos éticos desta pesquisa, bem como dúvidas que surjam posteriormente, poderei consultar diretamente as pesquisadoras responsáveis por esta pesquisa, a mestranda Monica Chaves (e-mail: kikalu@globo.com, telefone pessoal: (021) 24930438, e seus orientadores, profa. Dra. Cilene Rodrigues (crodrigues@puc-rio.br, telefone pessoal: (021) 98055-1025, http://www.letras.pucrio.br/br/docente/24/cilene-aparecida-nunes-rodrigues), responsável por esta pesquisa no Departamento de Letras da PUC-Rio (Rua Marquês de S. Vicente, 225 Ala Kennedy, sala K-121 Gávea - Rio de Janeiro, CEP: 22451-900; +55 (21) 3527-1297, e prof. Dr. Daniel Mograbi (e-mail: danielmograbi@puc-rio.br, telefone pessoal: (021) 99993-2554, http://www.psi.pucrio.br/site/index.php/2015-03-29-11-14-38/corpo-dopcente1/quadro-principal/item/378-danielcorrea-mograbi), responsável por esta pesquisa no Departamento de Psicologia da PUC-Rio (Rua Marquês de S. Vicente, 225 Ala Kennedy, sala K-121 Gávea - Rio de Janeiro, CEP: 22451-900; +55 (21) 3527-1297).

Assinatura

Local/Data

Endereço

Telefone de contato

E-mail

Assinatura (Pesquisador):

Nome

Local/Data 